\title{
Lattice QCD Simulations beyond the Quenched Approximation
}

\author{
Akira Ukawa $\dagger$ \\ Theory Division, CERN, Geneva, Switzerland \\ Review presented at the GIFT International Seminar \\ on Non-Perturbative Aspects of the Standard Model \\ Spain, 6-11 June, 1988
}

\begin{abstract}
Present status of lattice QCD simulations incorporating the effects of dynamical quarks is presented. After a brief review of the formalism of lattice QCD, the dynamical fermion algorithms in use today are described. Recent attempts at the hadron mass calculation are discussed in relation to the quenched results, and current understanding on the finite temperature behavior of QCD is summarized.
\end{abstract}

CERN-TH-5245/88

December 1988

$\dagger$ On leave from Institute of Physics, University of Tsukuba, Ibaraki 305, Japan. 

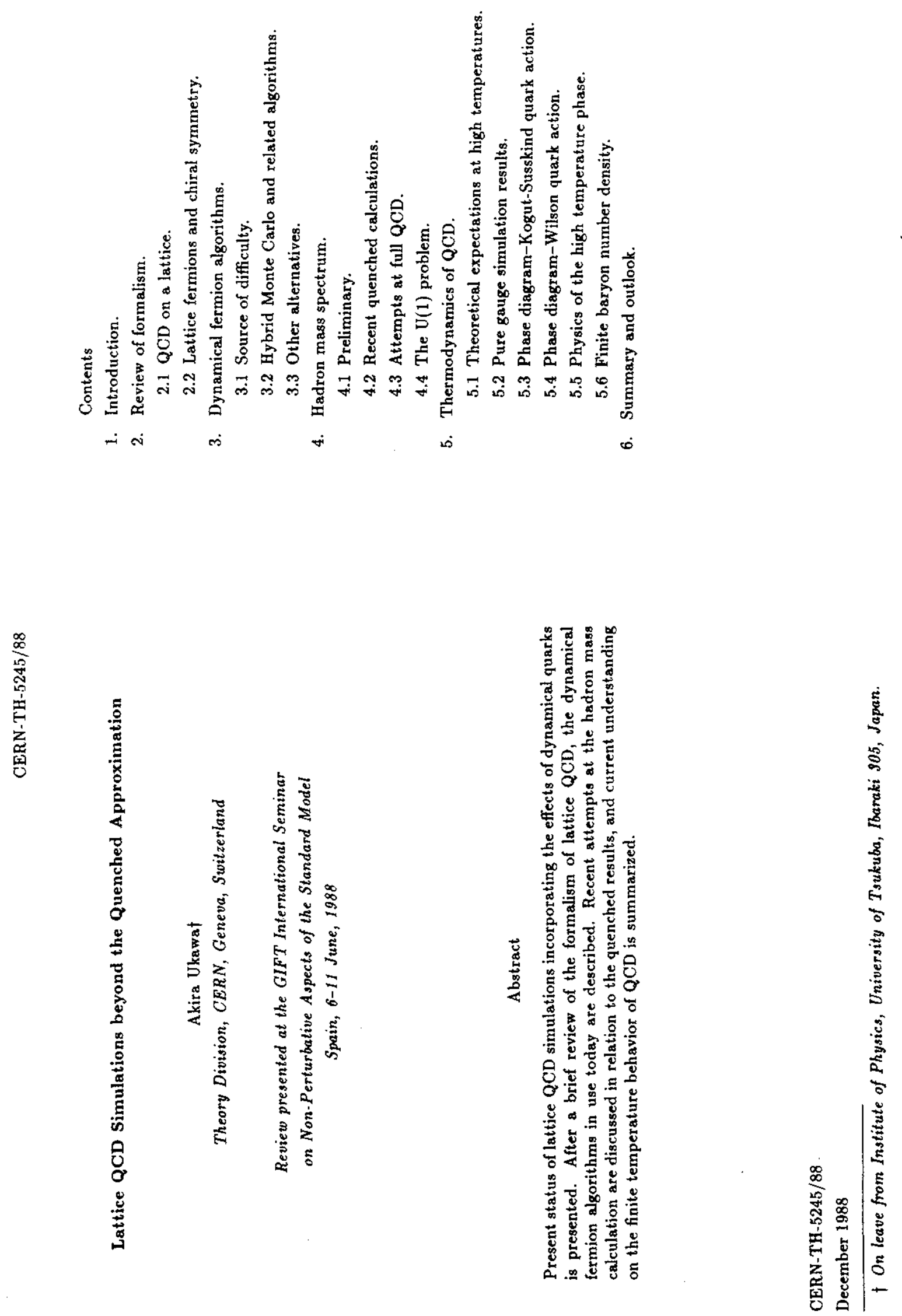


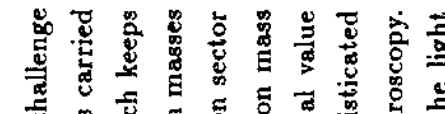

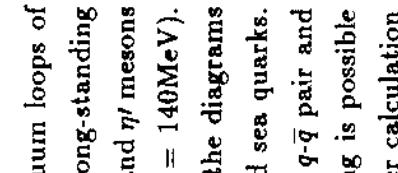
至

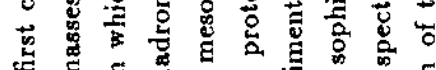

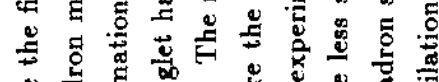

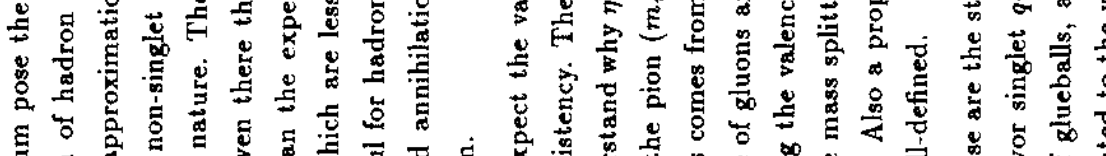

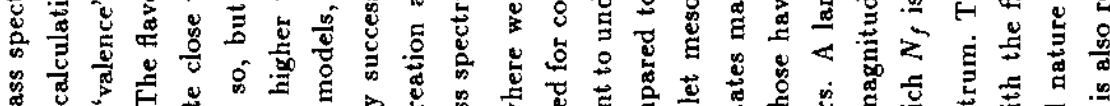

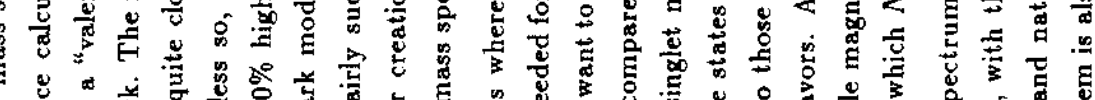

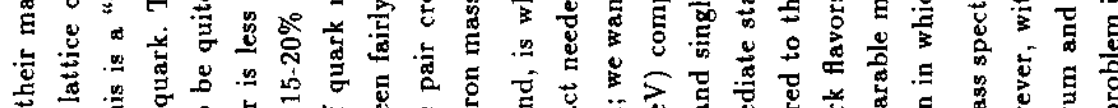

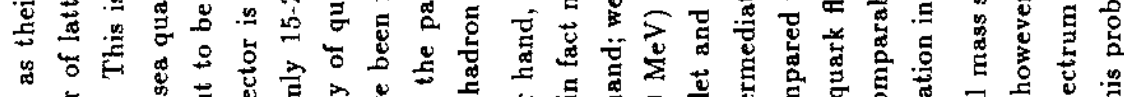

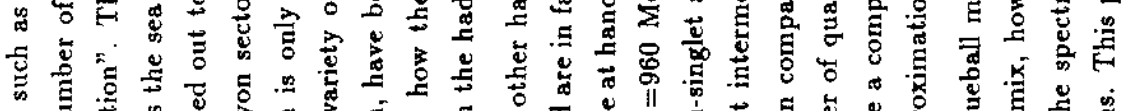

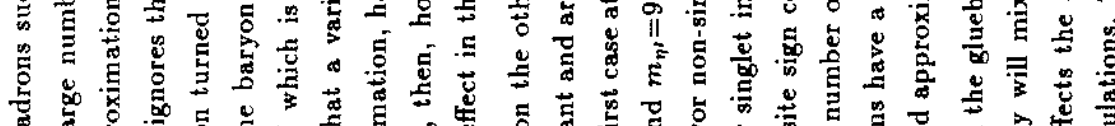

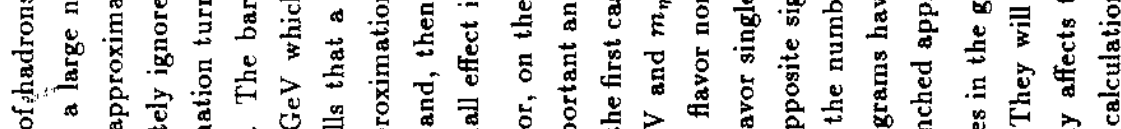

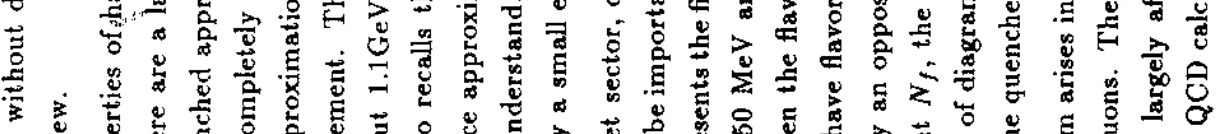

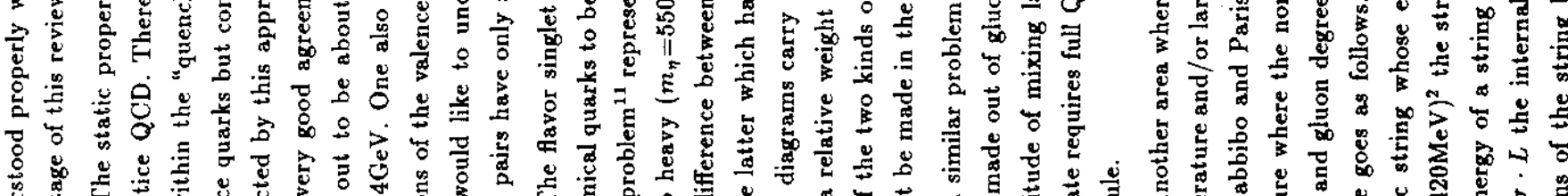

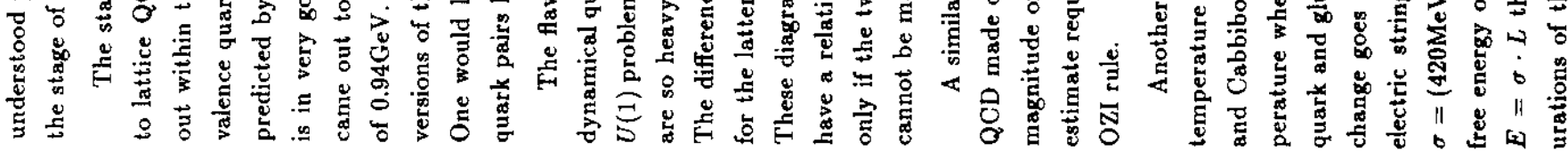

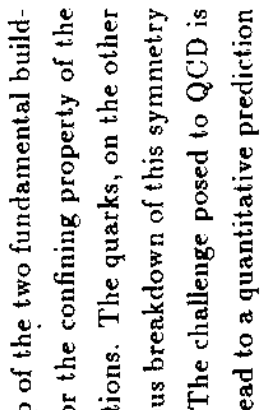

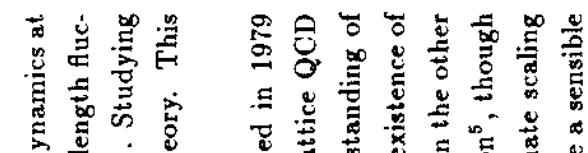

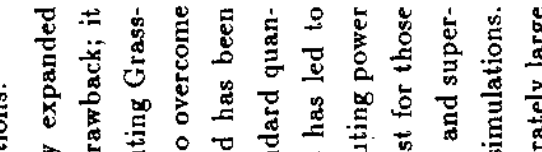
密 离

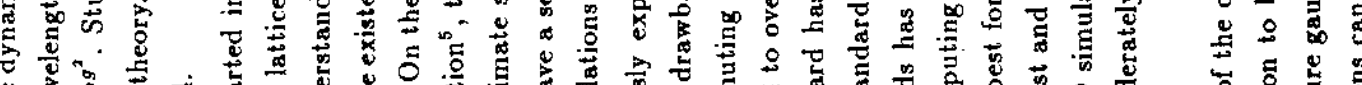

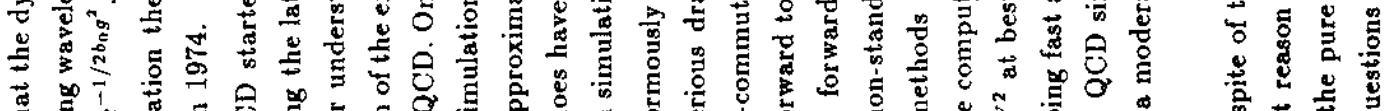

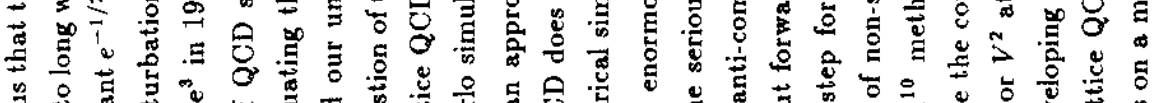

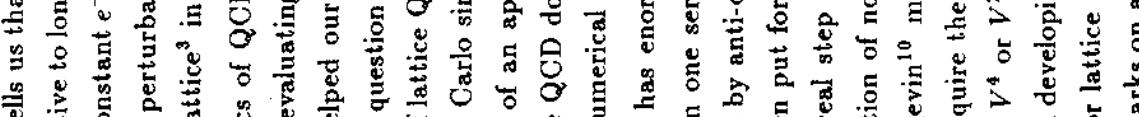

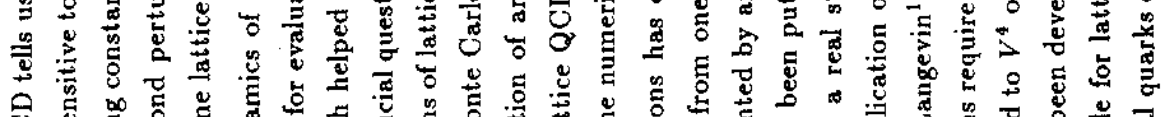

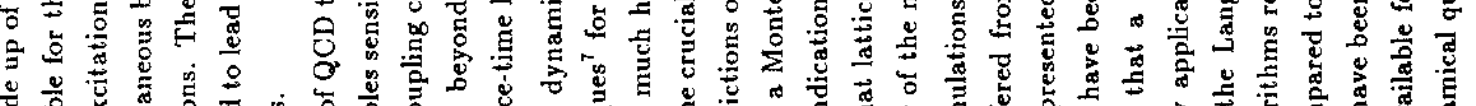

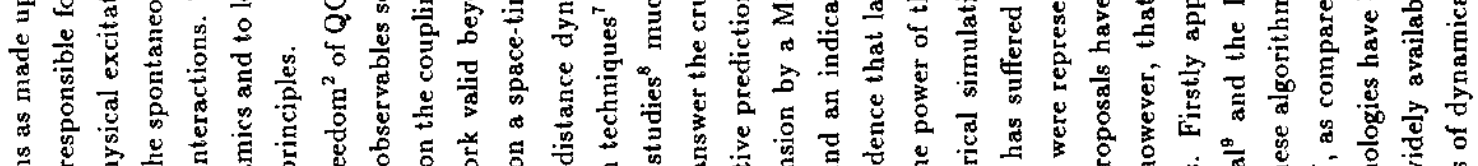

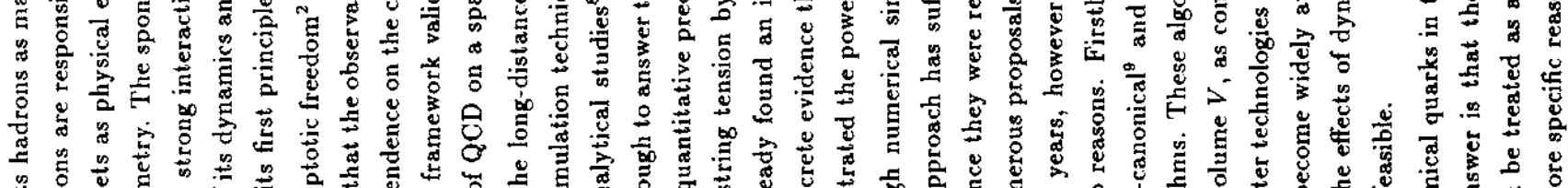

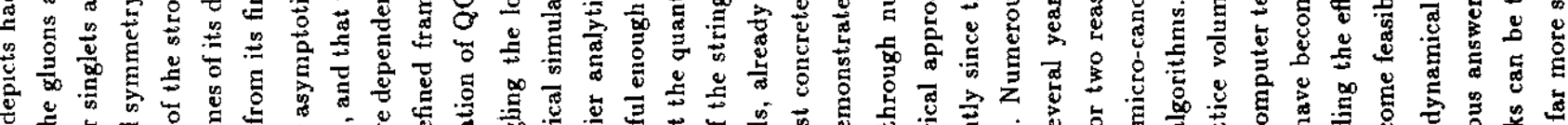

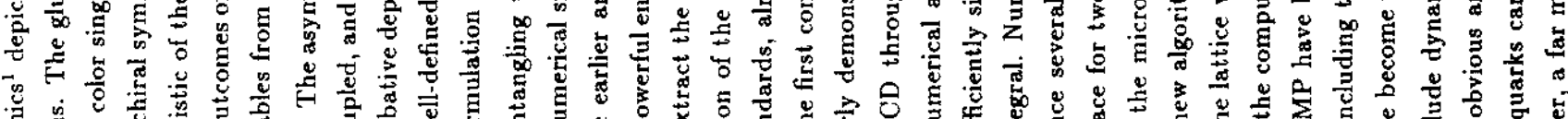

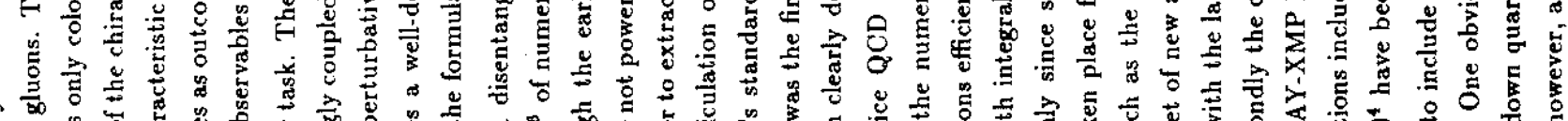
至

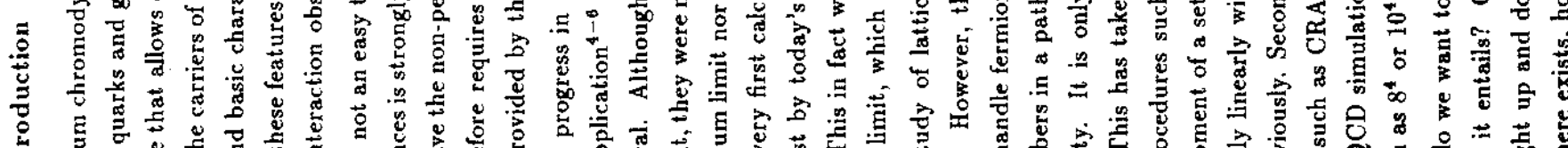
节 至

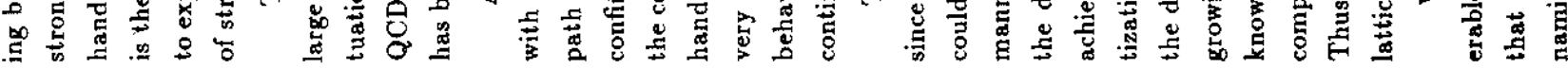




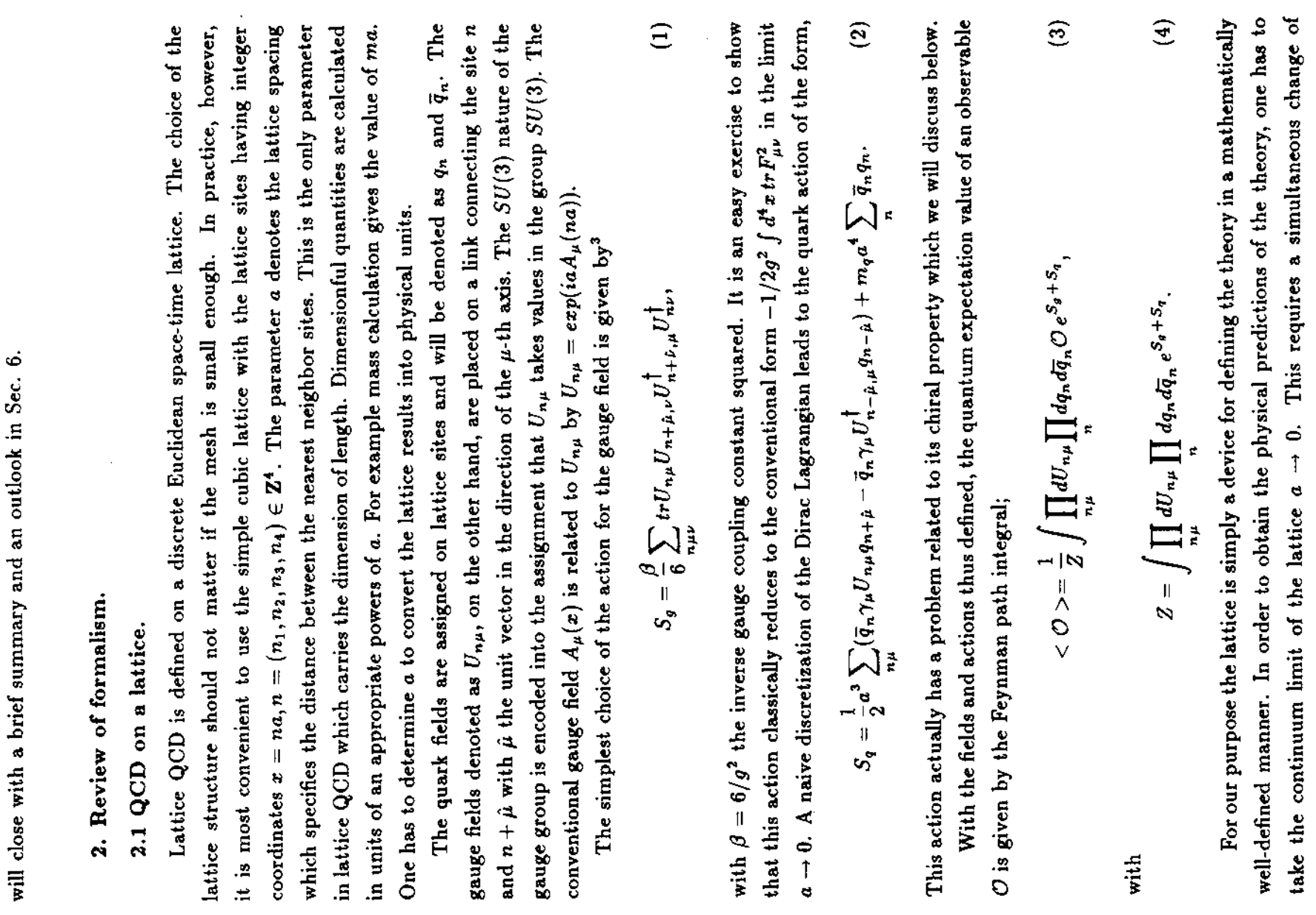

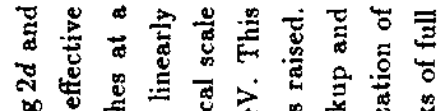

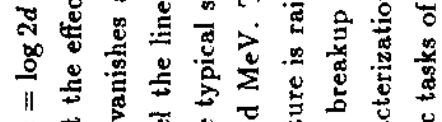

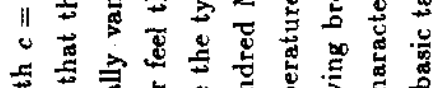

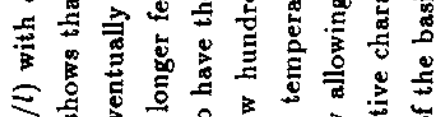
곡ำ

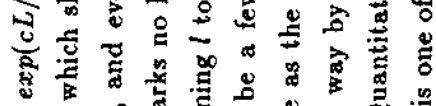
แล s. 8. 2.

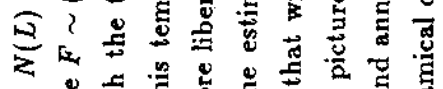

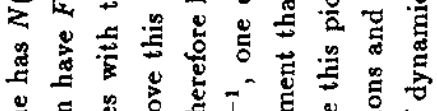
呟 -

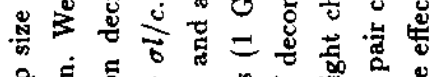
shenth

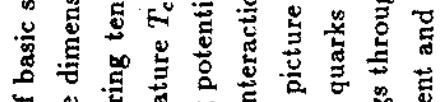
Ind औ sing

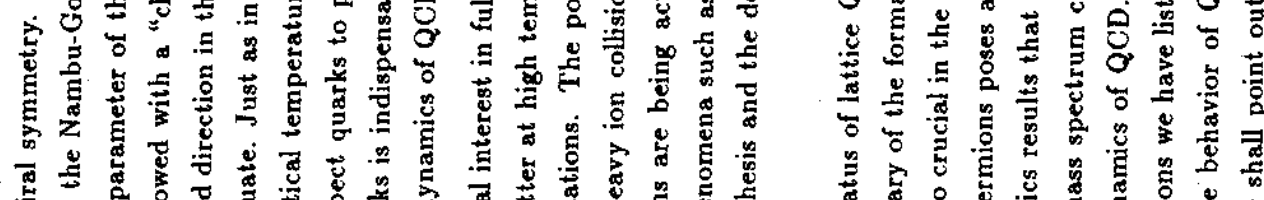

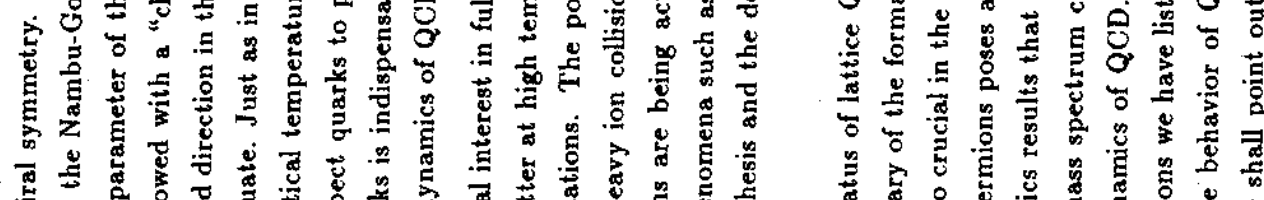

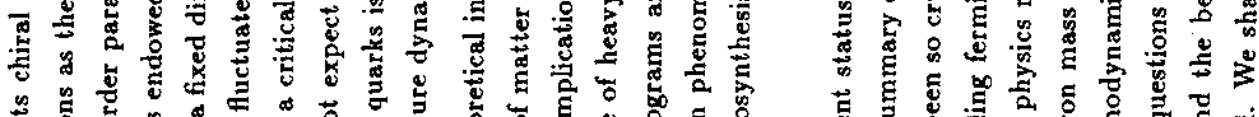

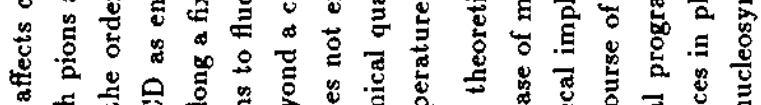

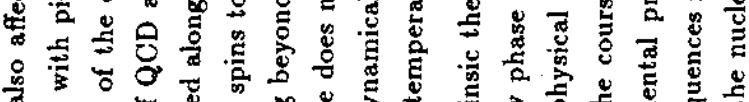

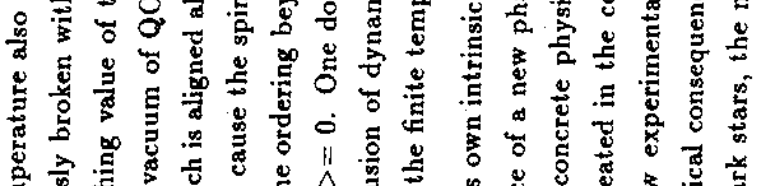

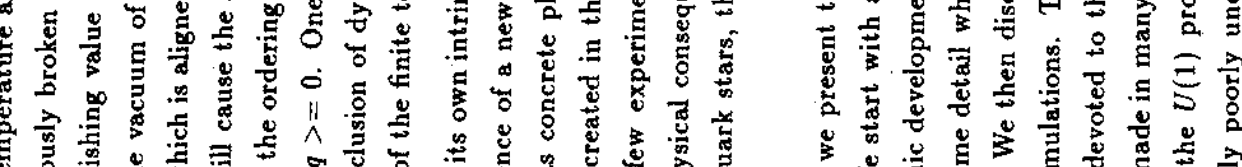

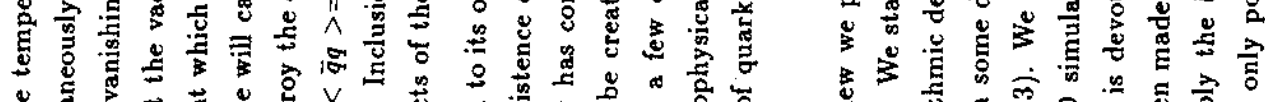

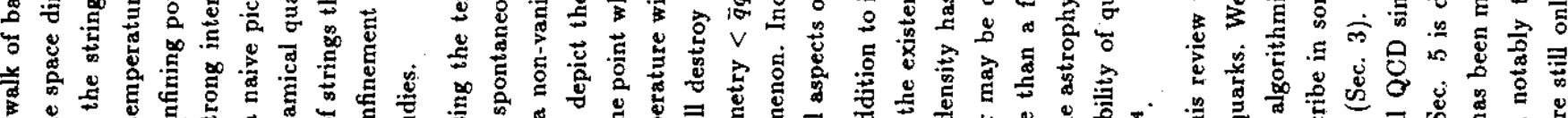

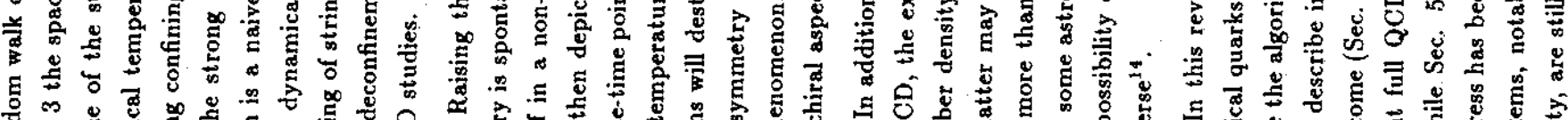

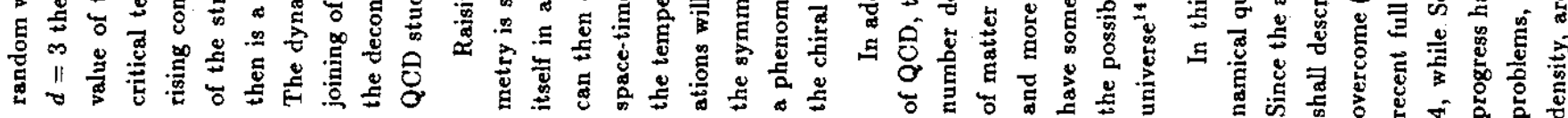




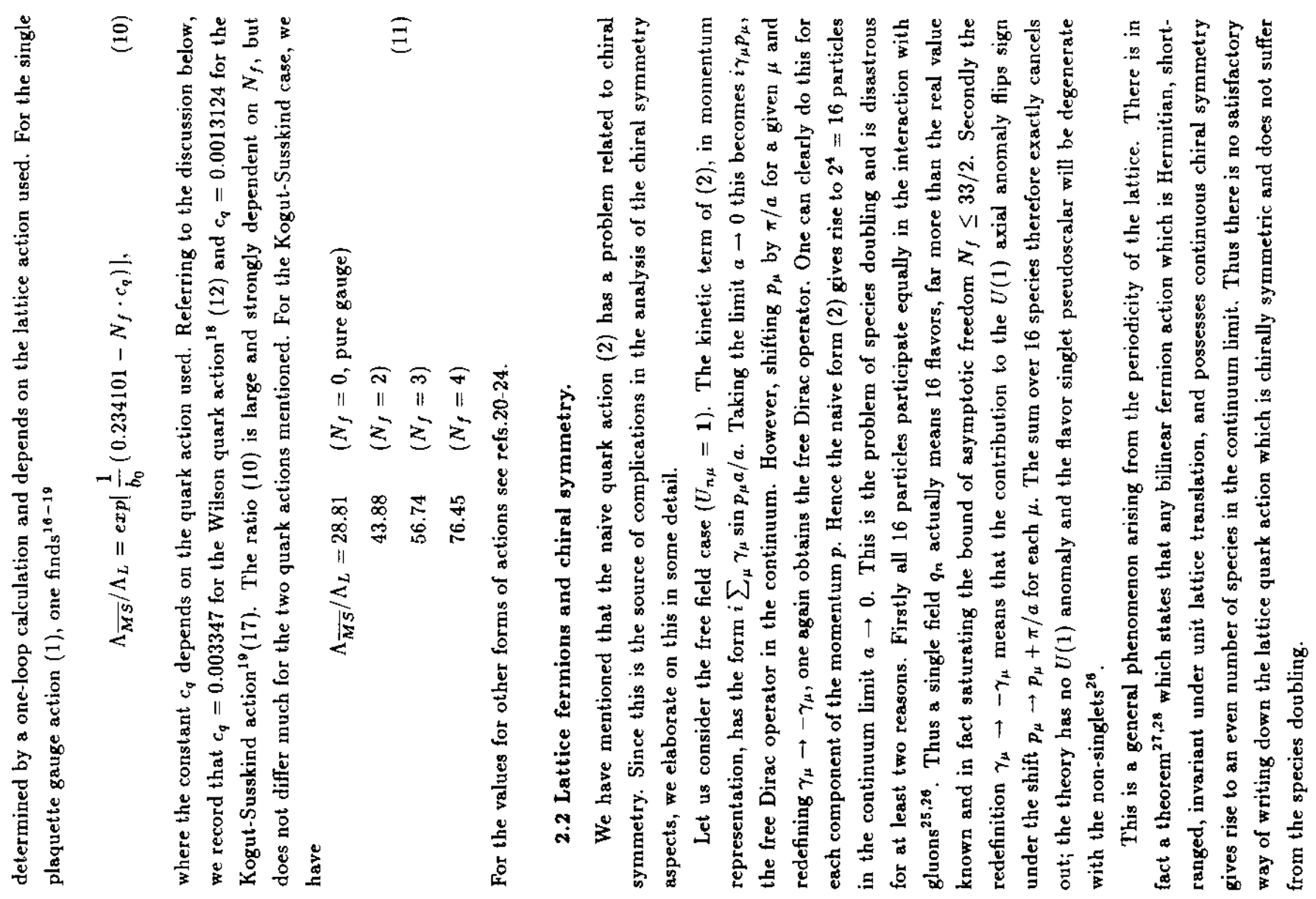

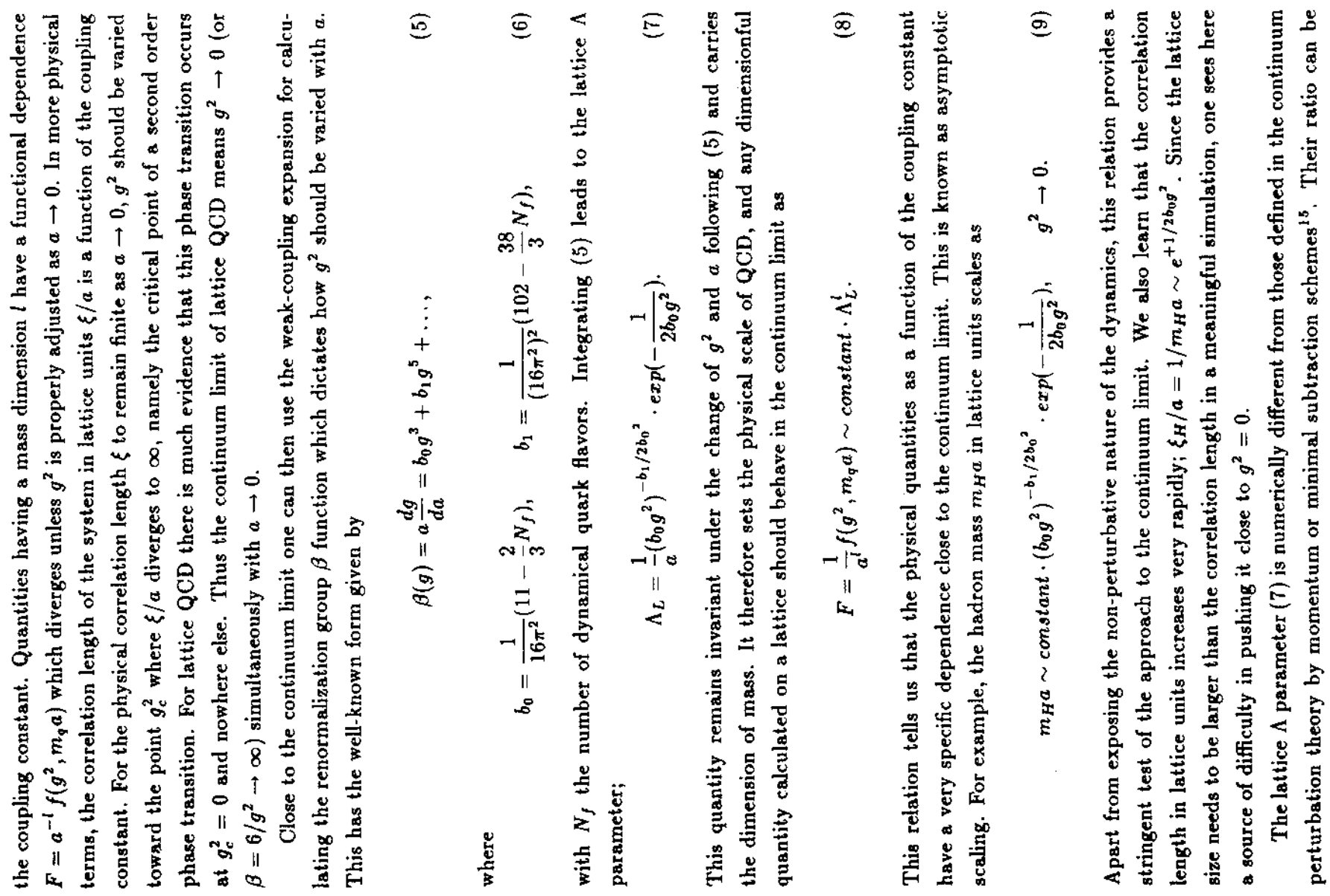



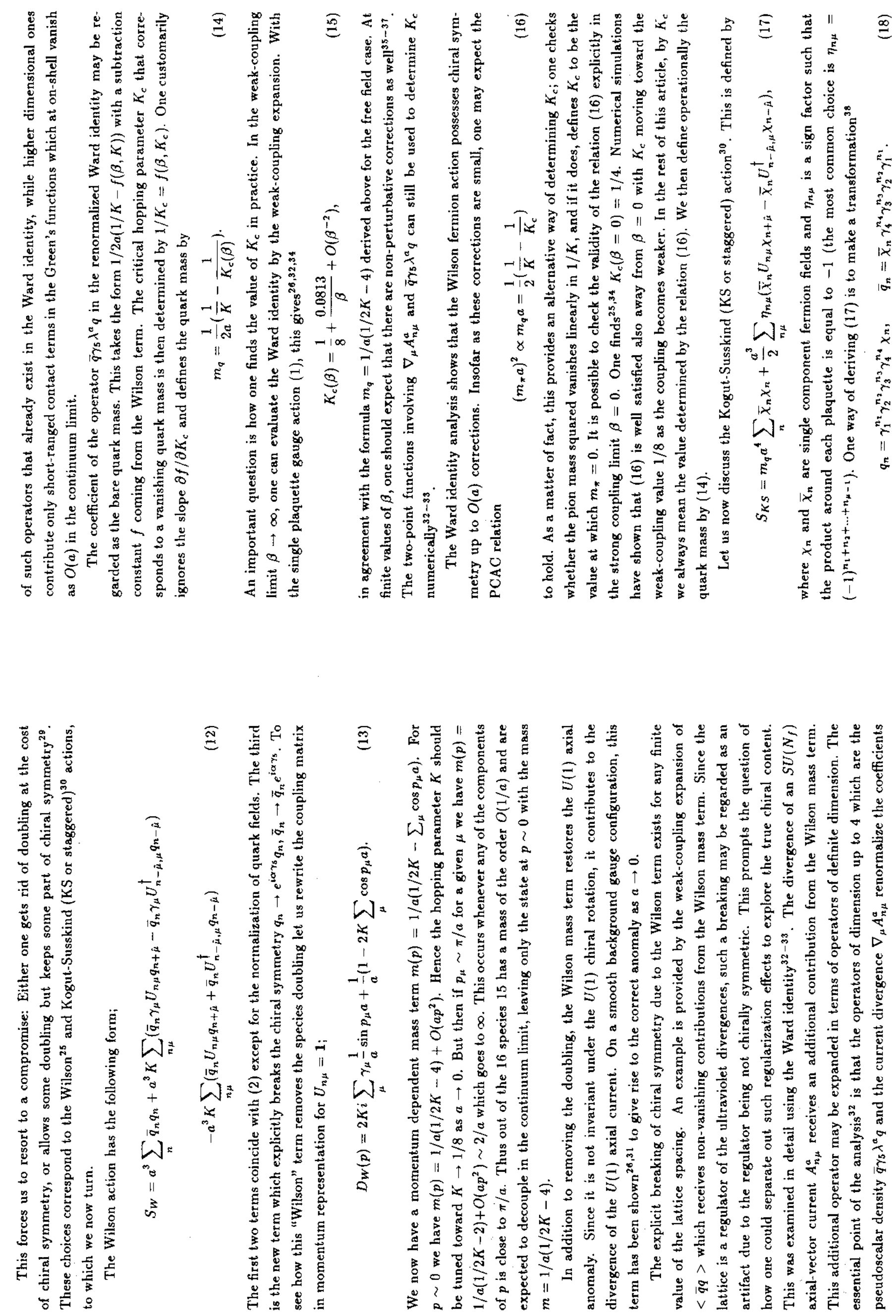


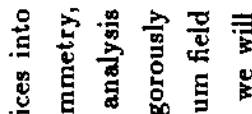

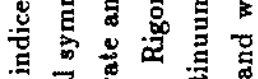

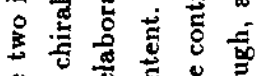

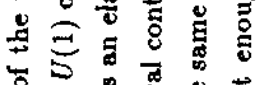

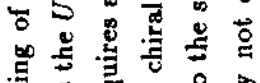

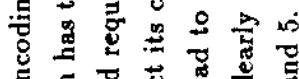

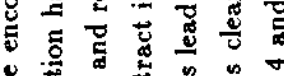

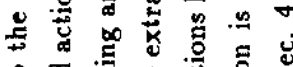

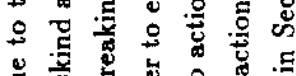

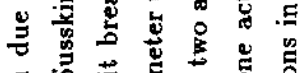

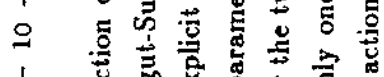

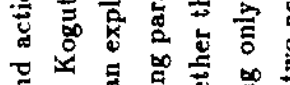

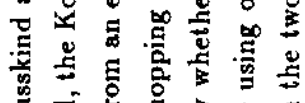

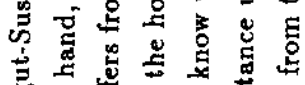

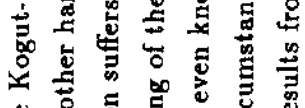

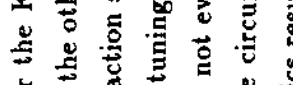

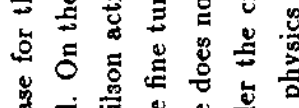

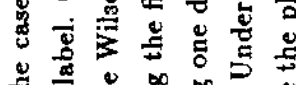

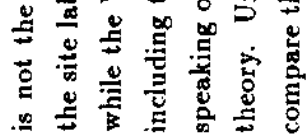

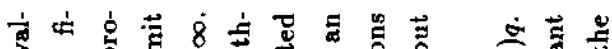

s.

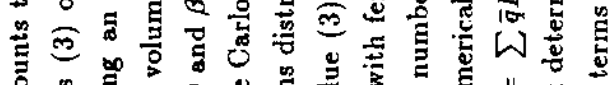

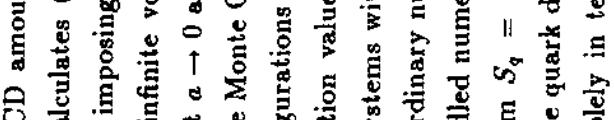

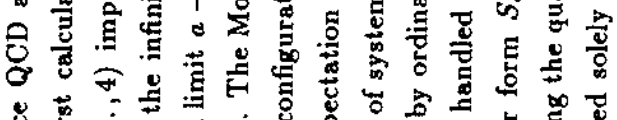

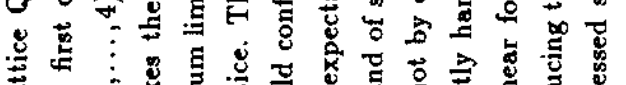

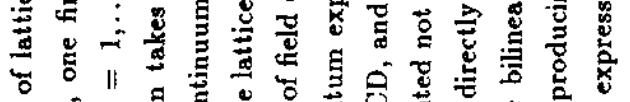

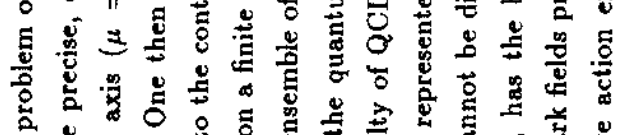

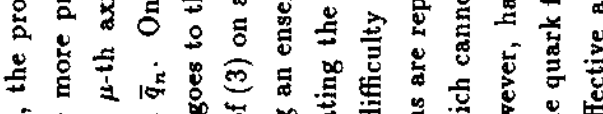

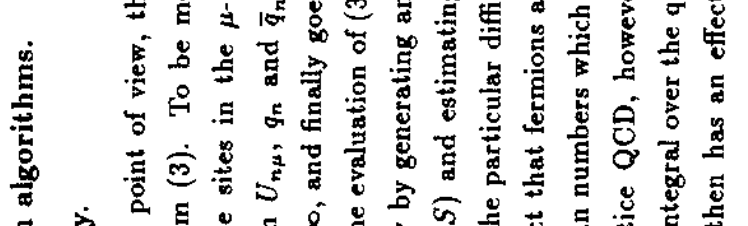

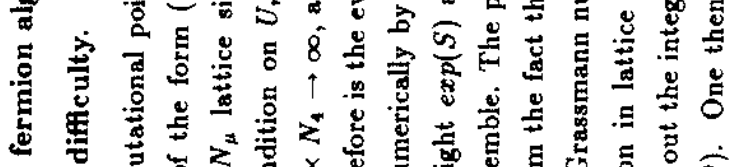

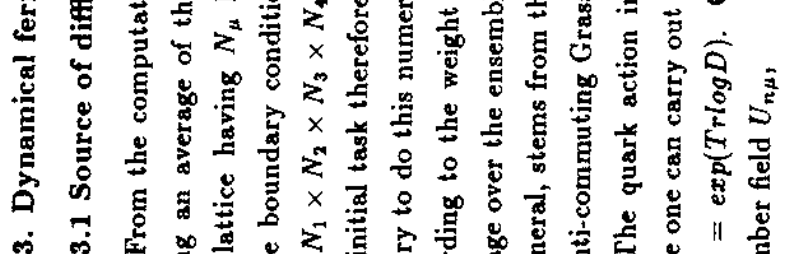

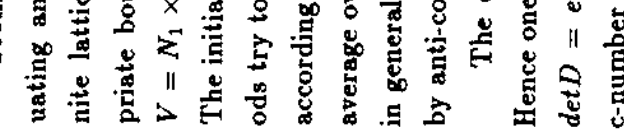

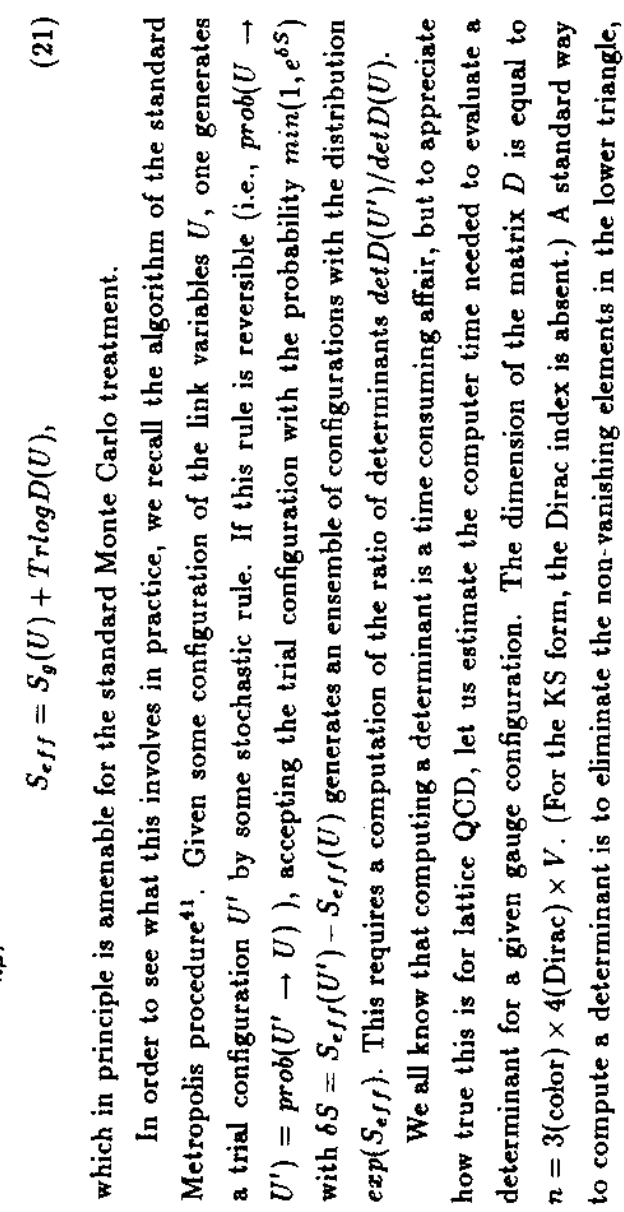

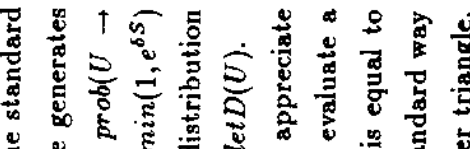

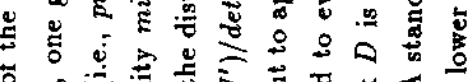

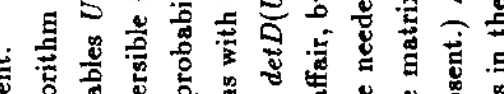

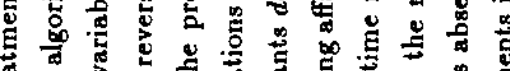

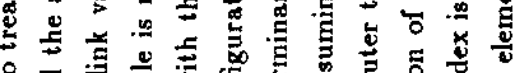
ช

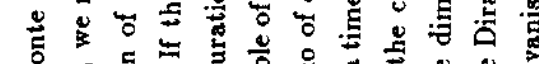

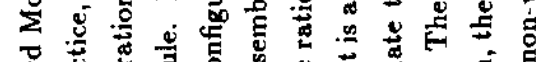

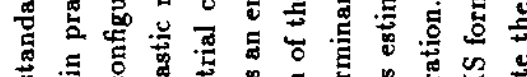

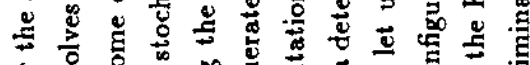

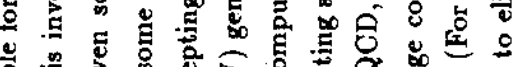

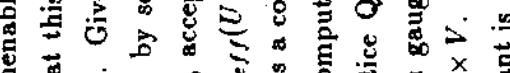

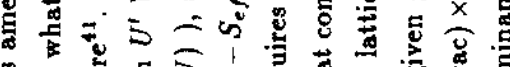

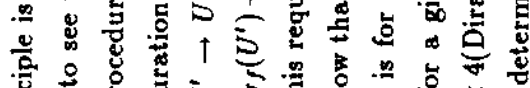

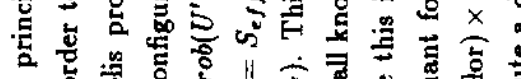

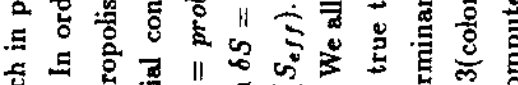

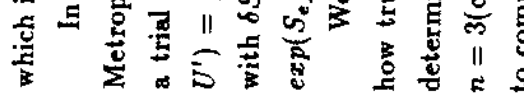

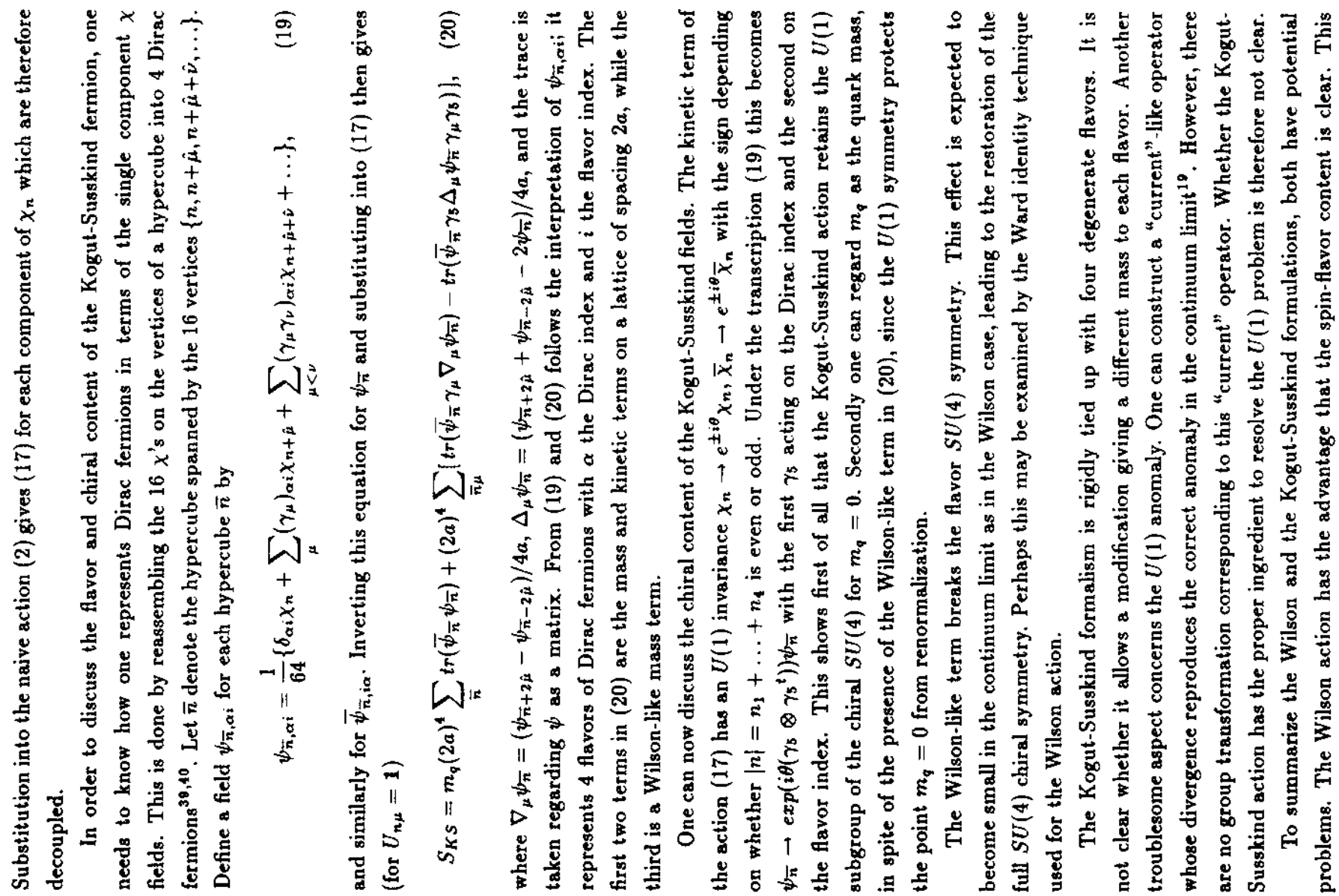




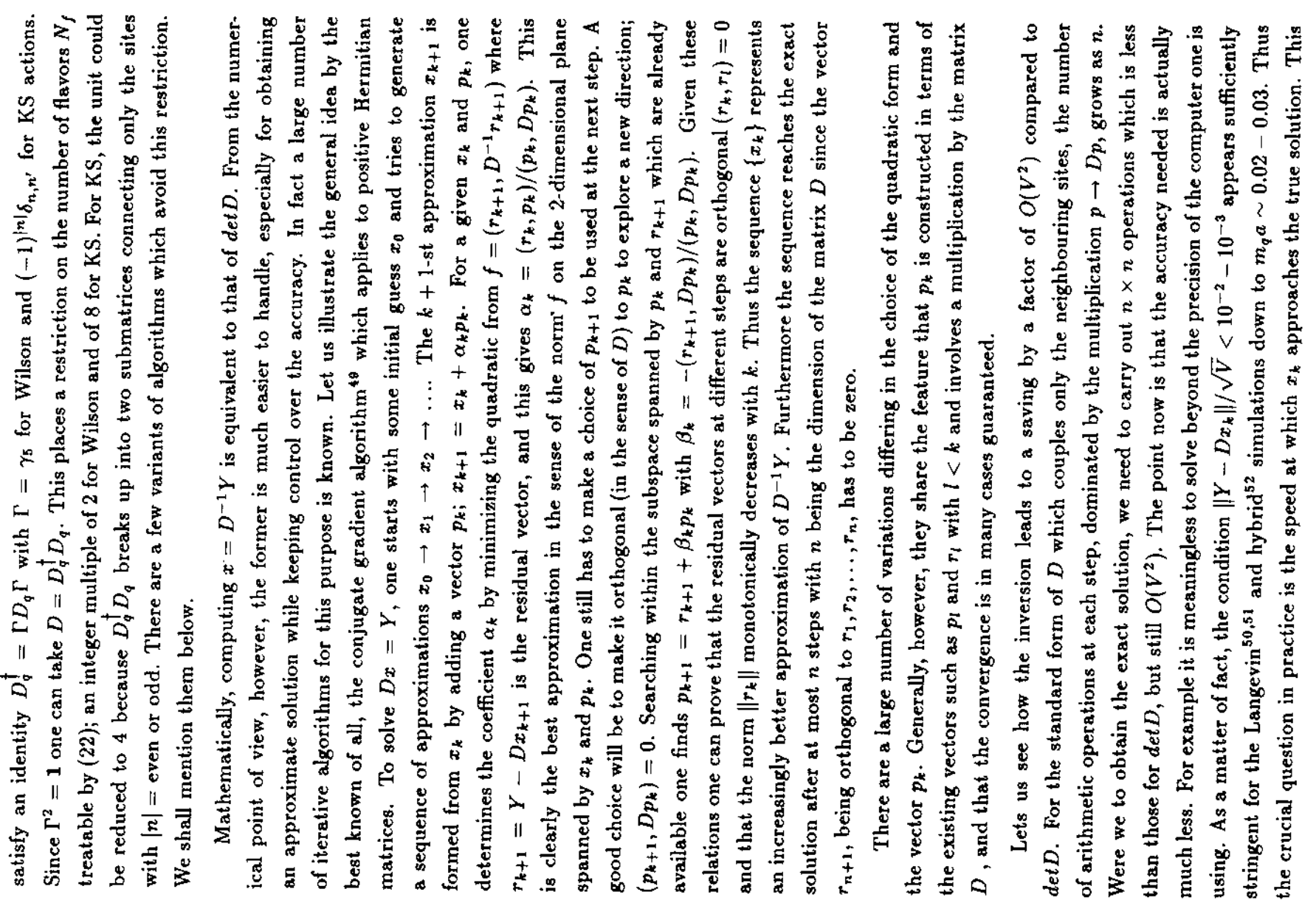

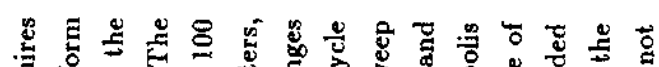

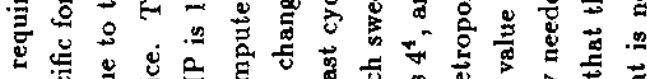

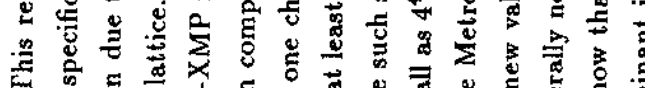

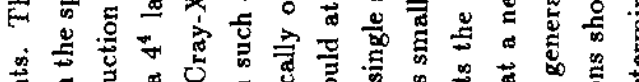

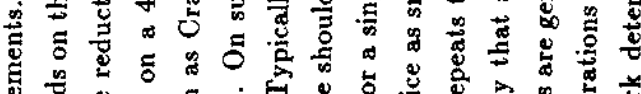

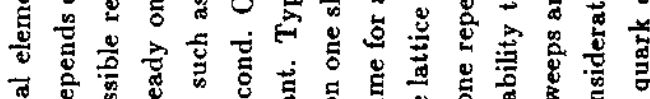

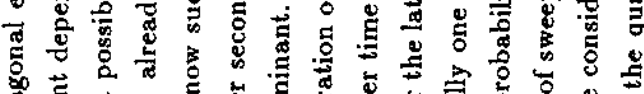

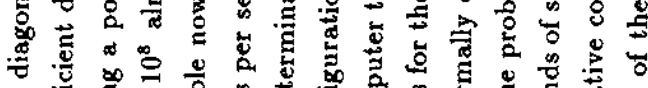

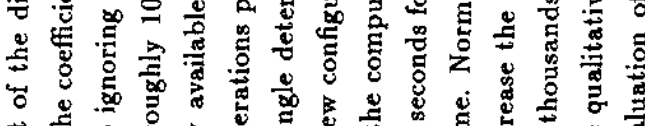

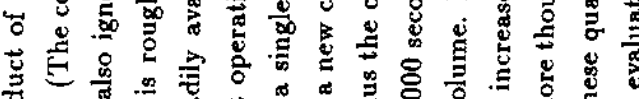

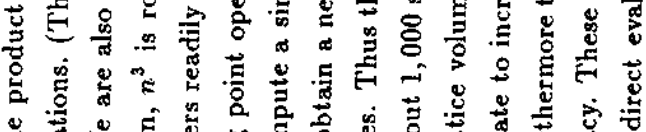

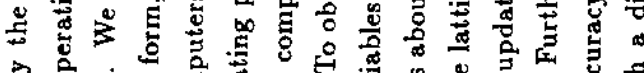

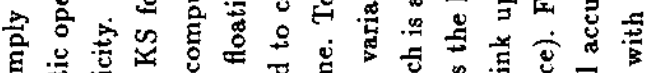

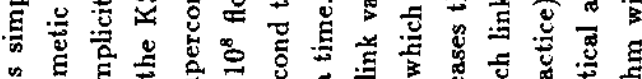

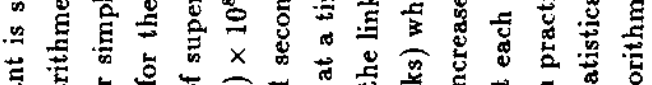

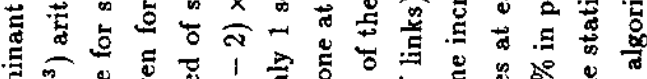

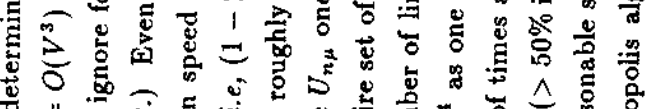

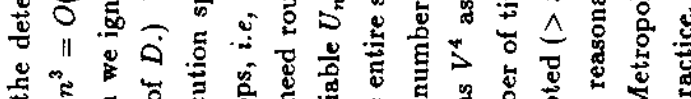

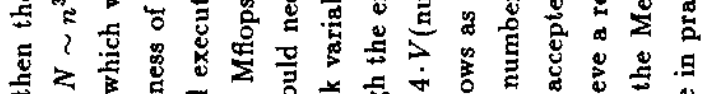

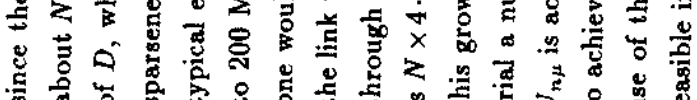

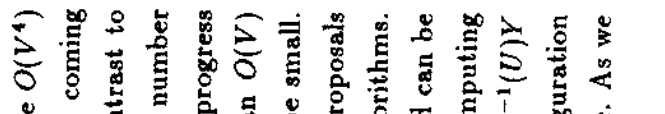

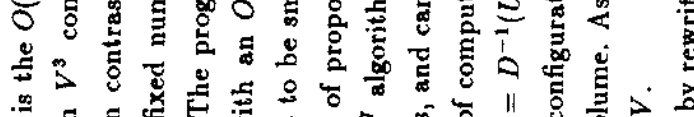

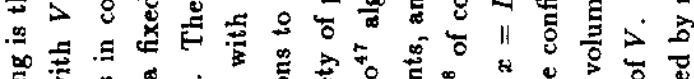

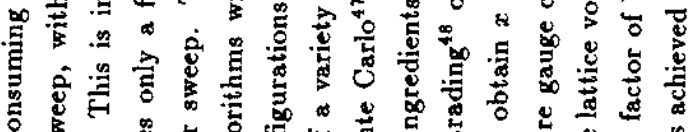

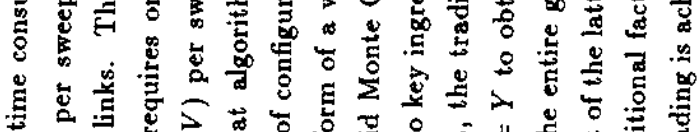

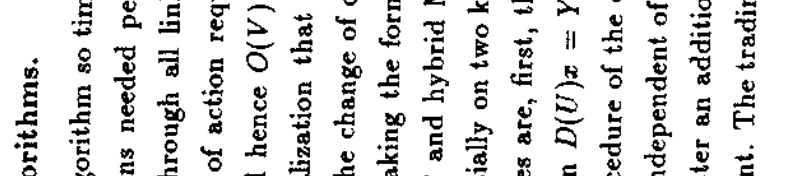

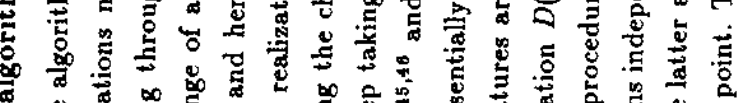

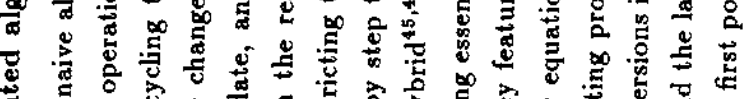

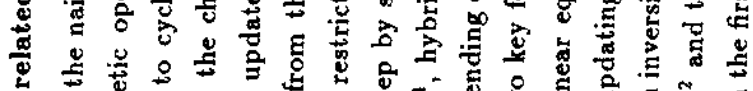

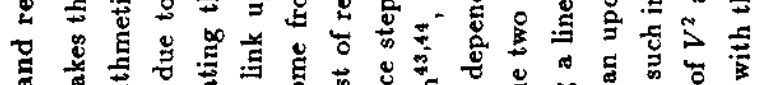

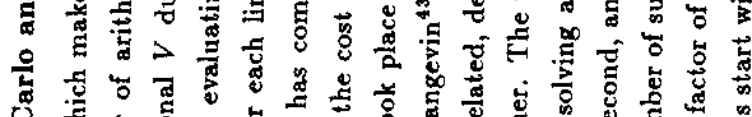

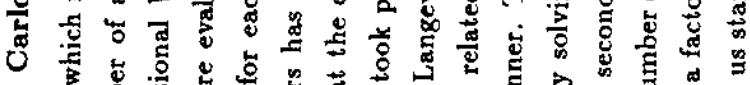

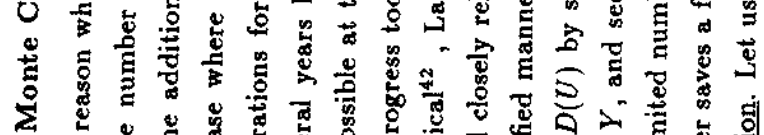

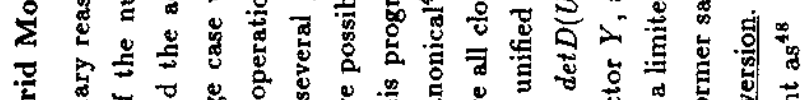

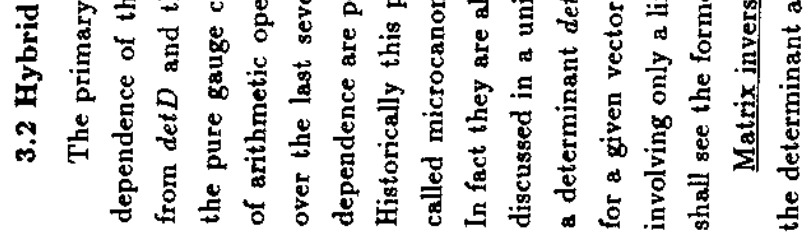

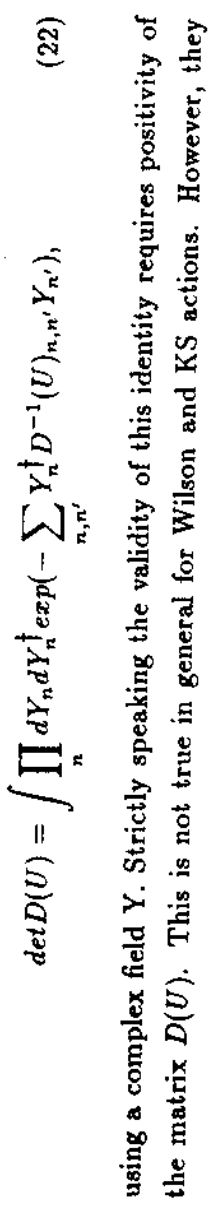



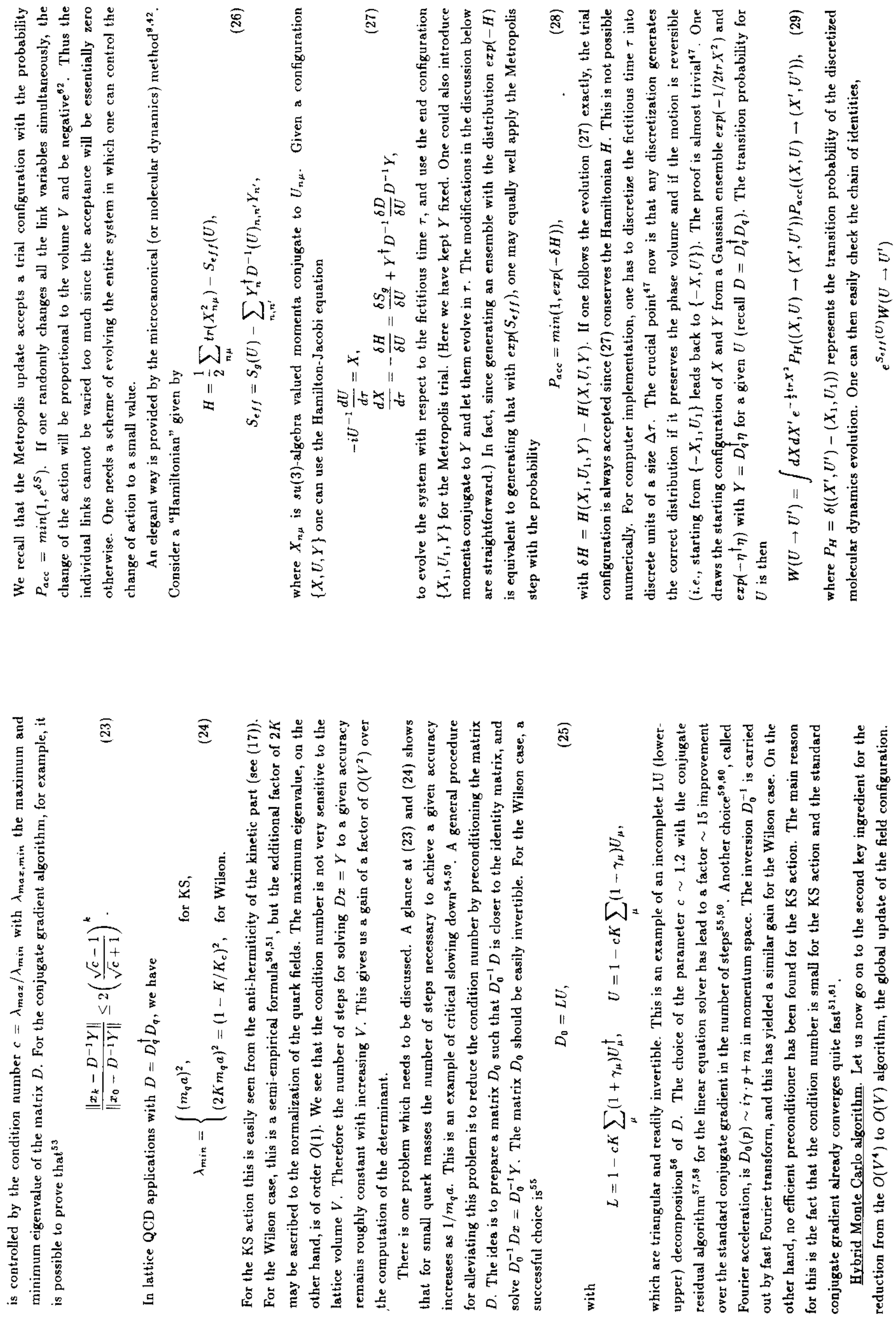


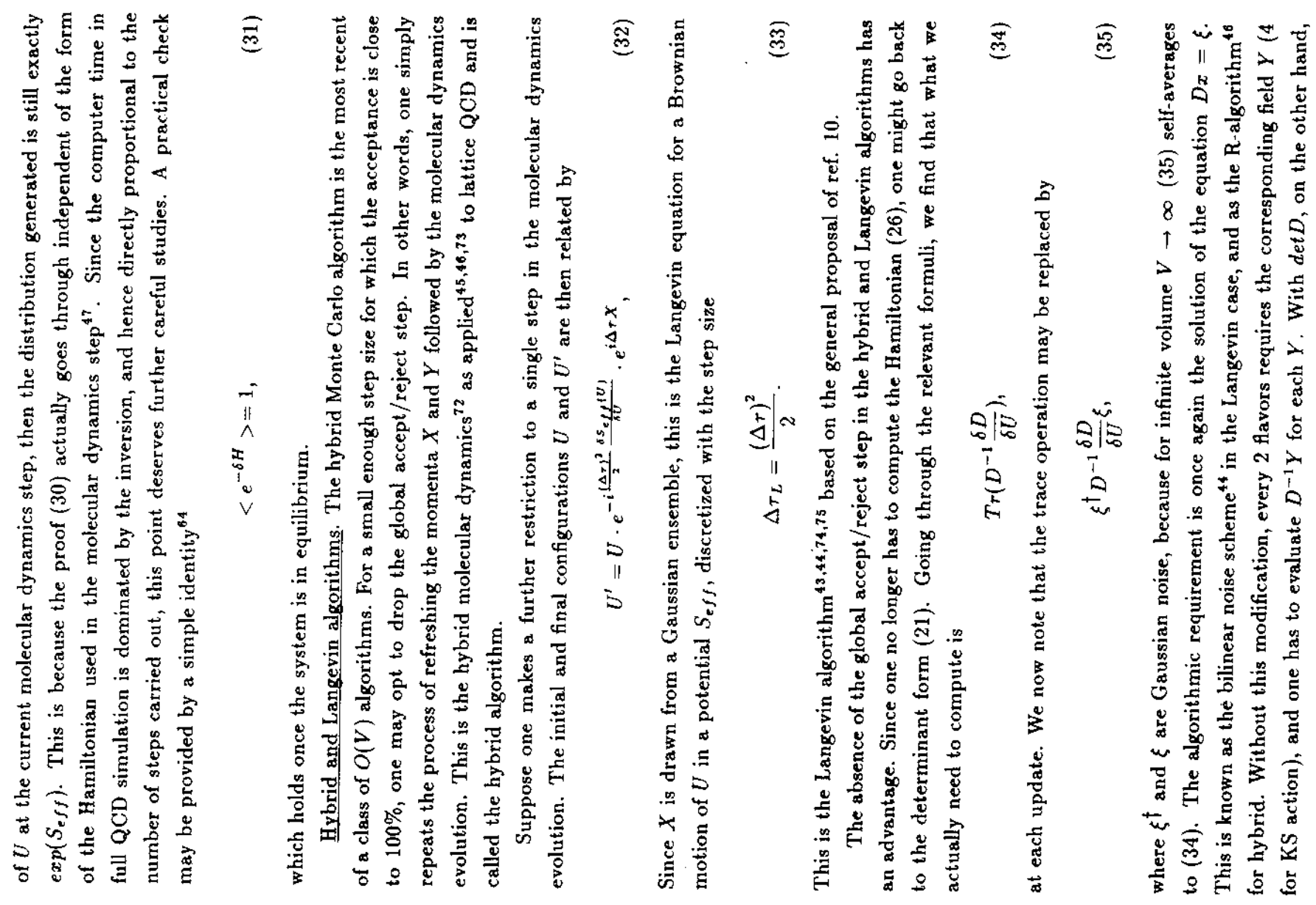

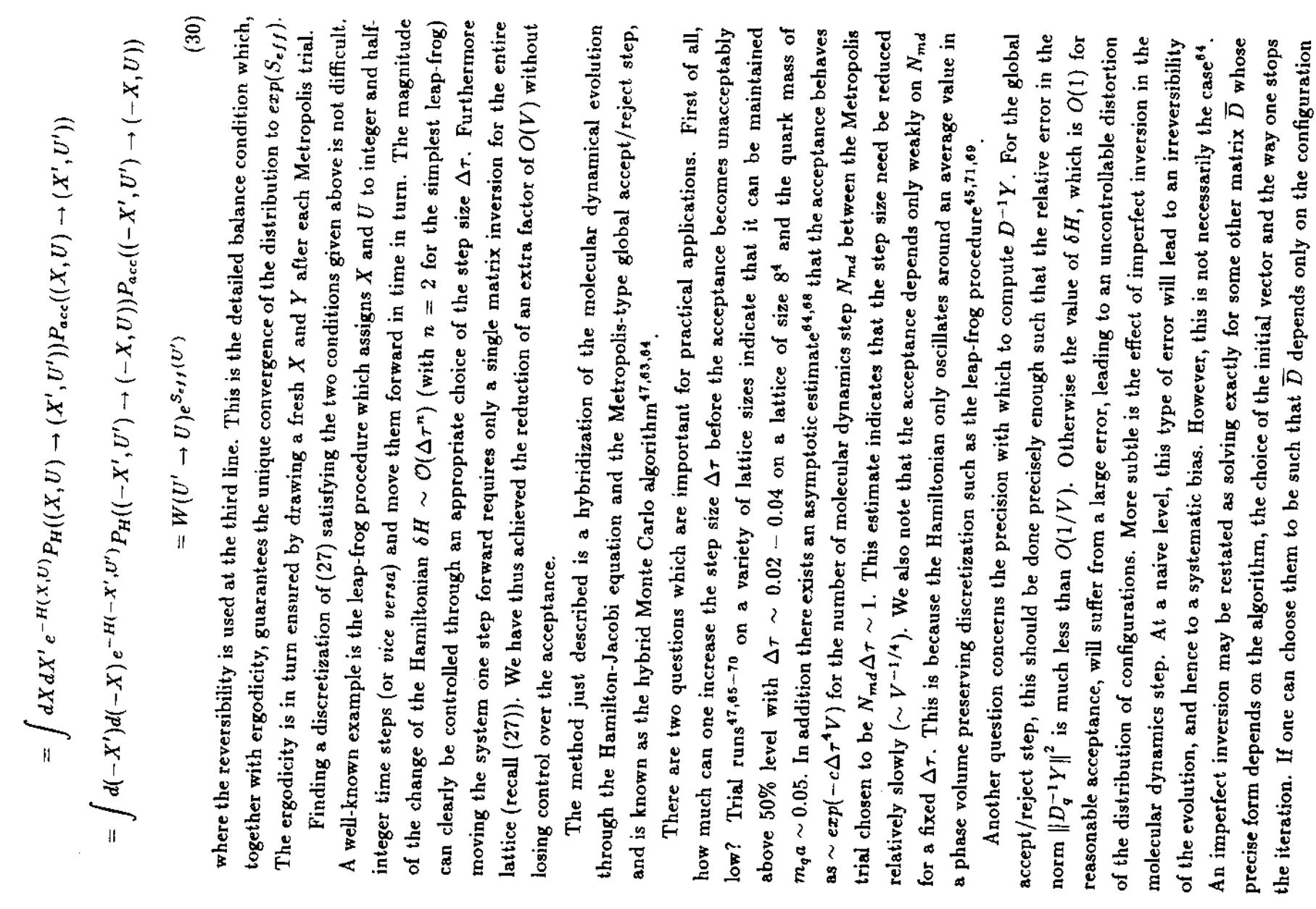




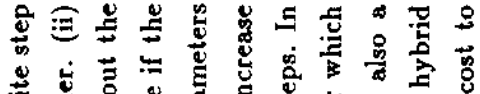

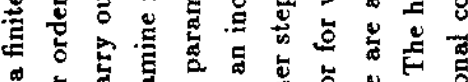

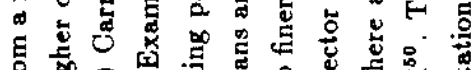

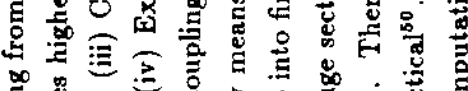

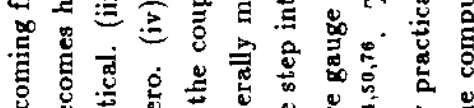

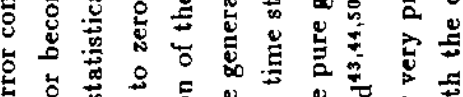

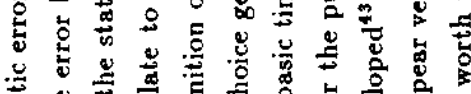

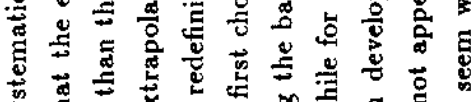

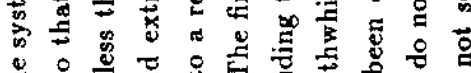

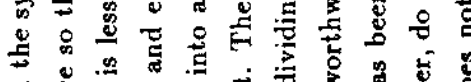

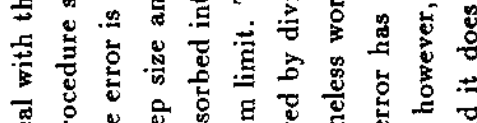

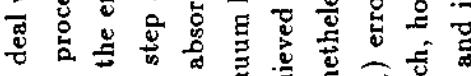

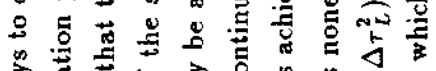

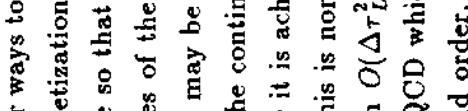

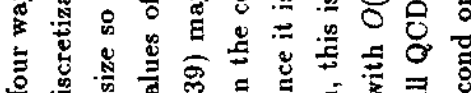

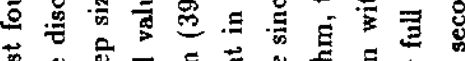

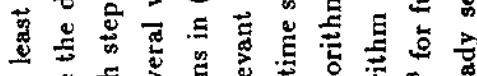

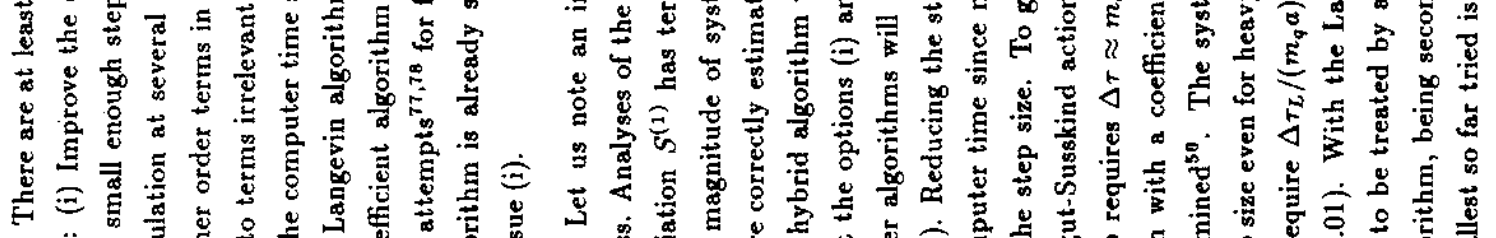

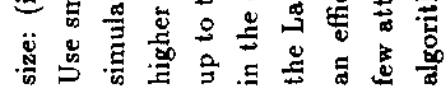

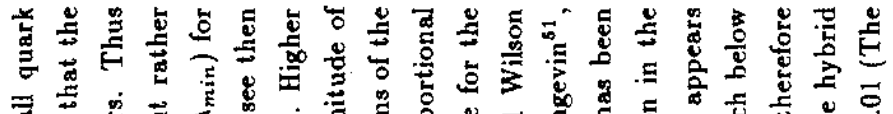

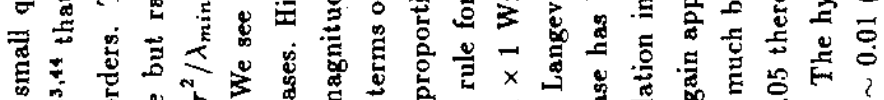

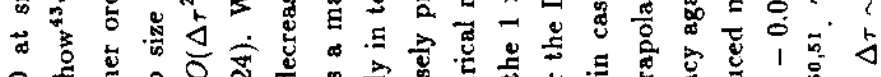

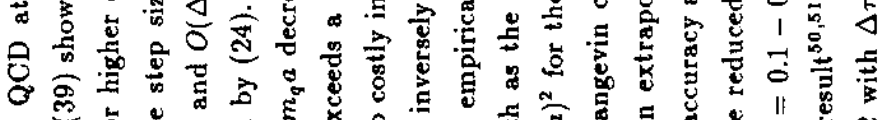

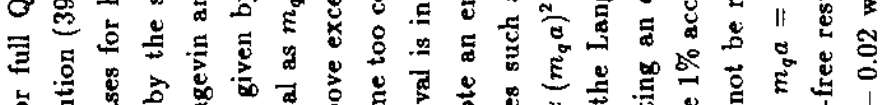

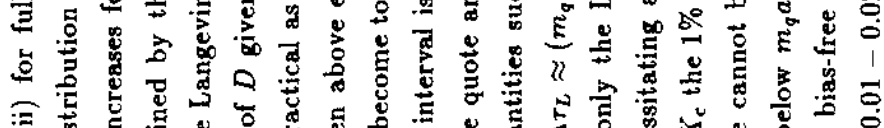

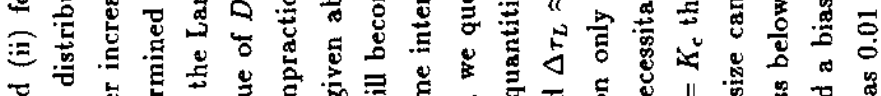

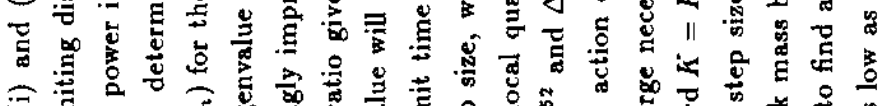

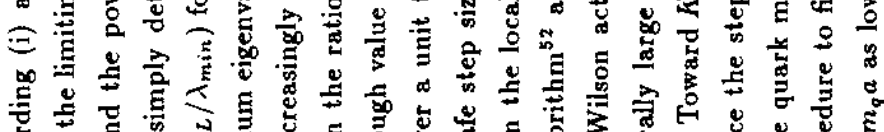

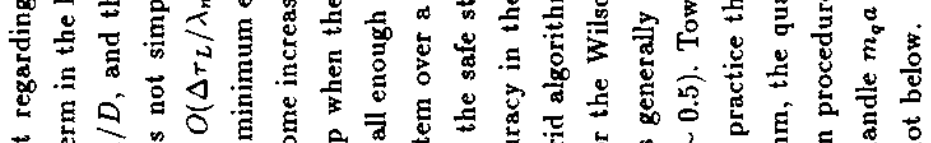

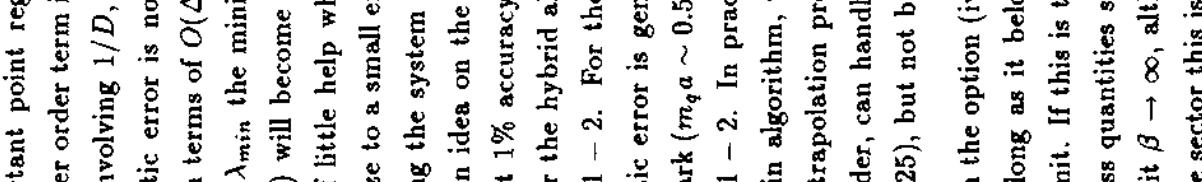

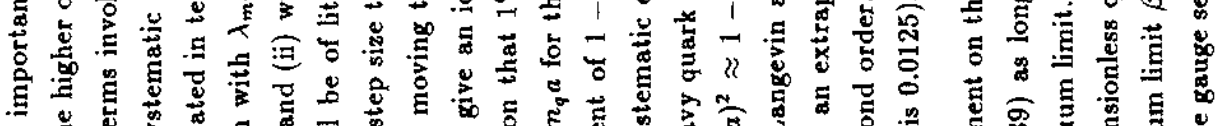

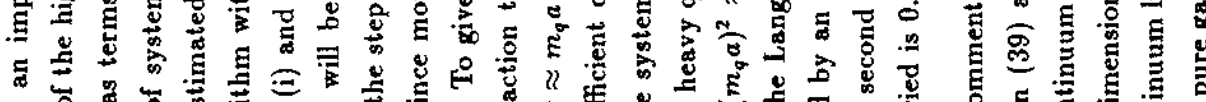

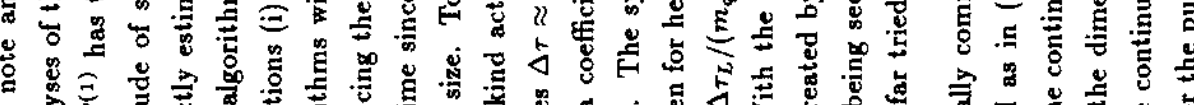

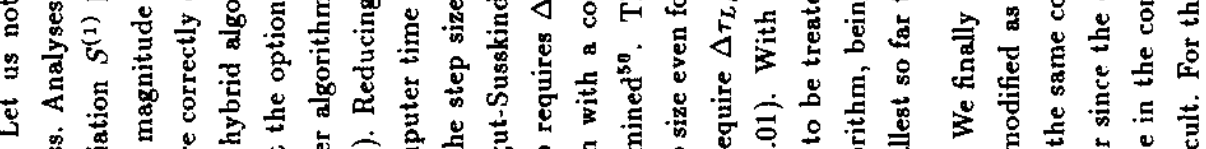

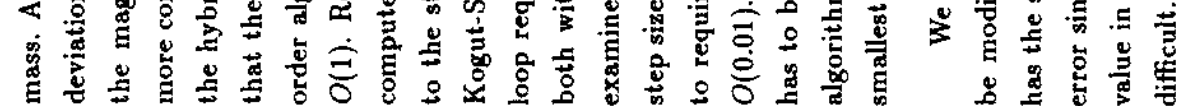

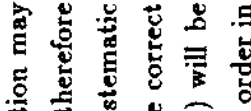

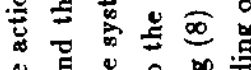

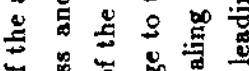

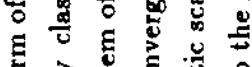

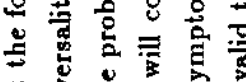

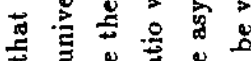

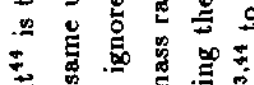

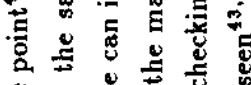

竎

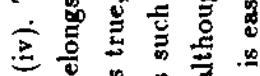

苾

高势要

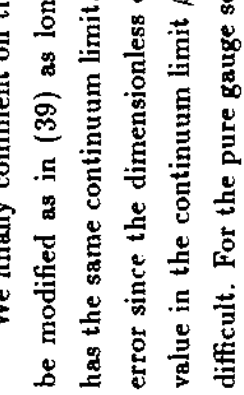

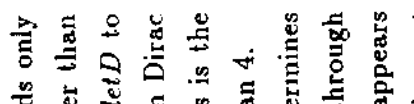

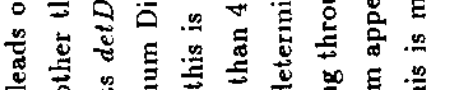

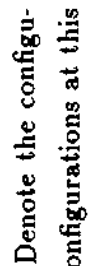

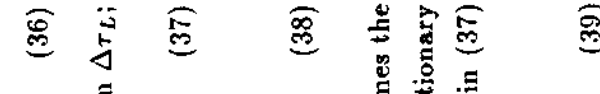

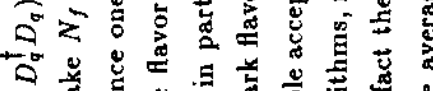

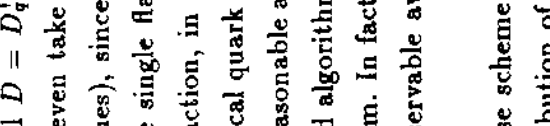

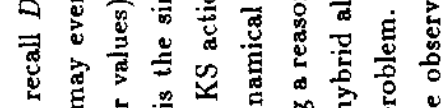

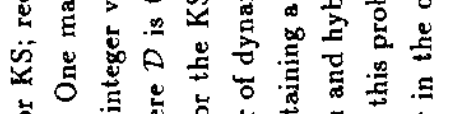

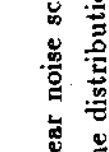

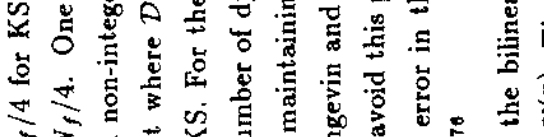

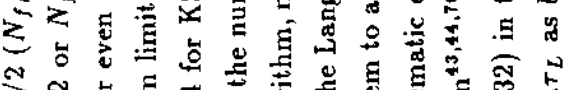
N

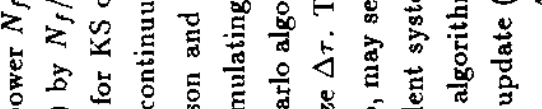

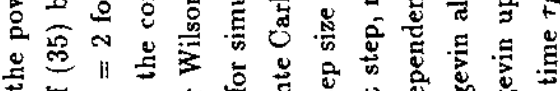

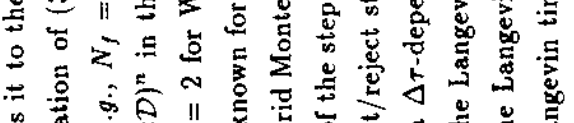

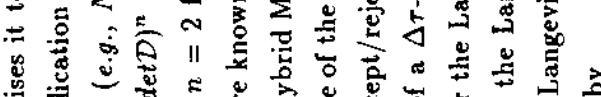

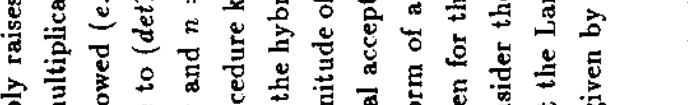

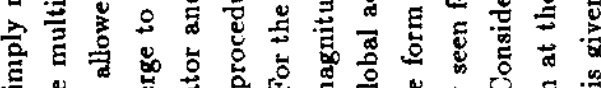

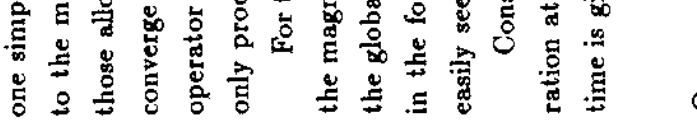

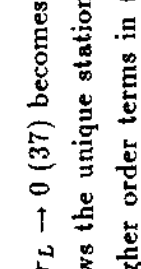
守

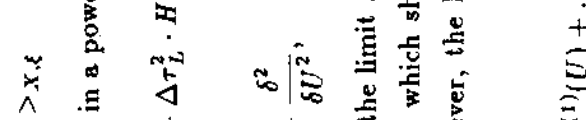

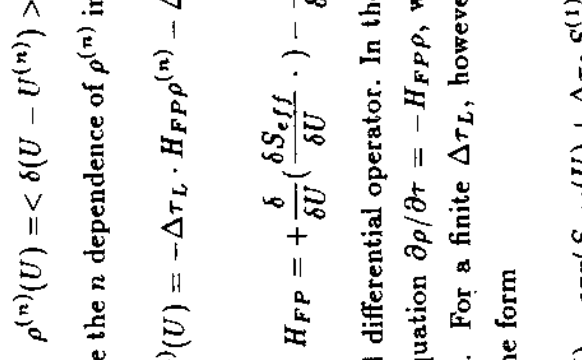

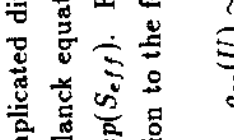

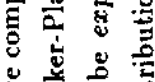

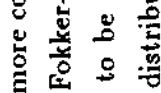

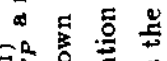

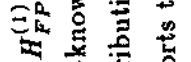

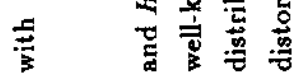




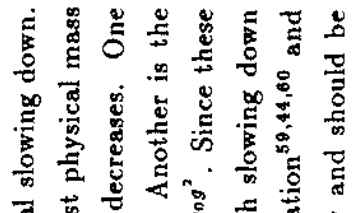

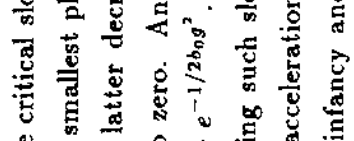

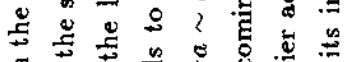

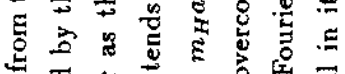

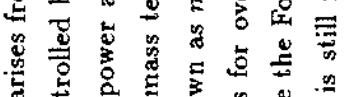
6.

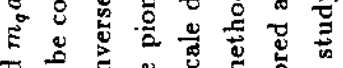

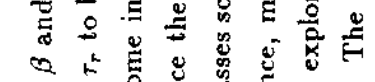
5

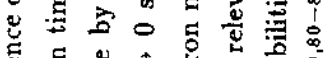

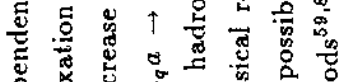

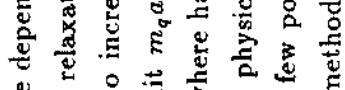

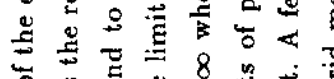

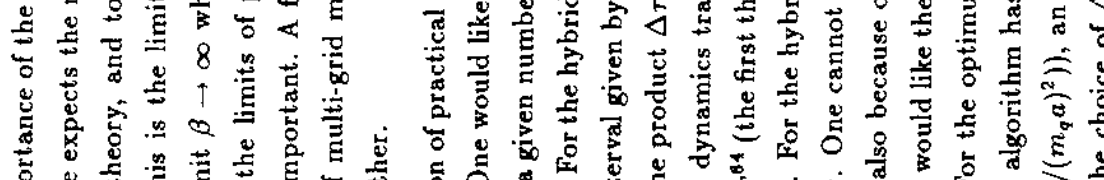

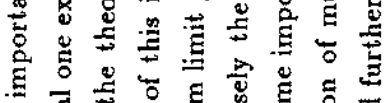

$\stackrel{\mathscr{2}}{\mathrm{E}}$

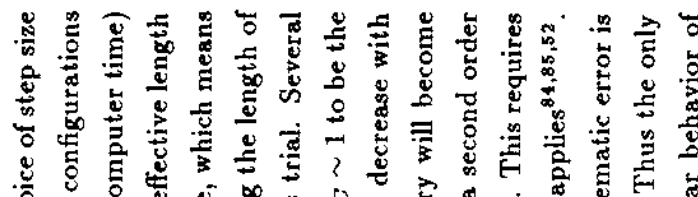

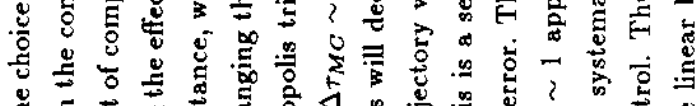

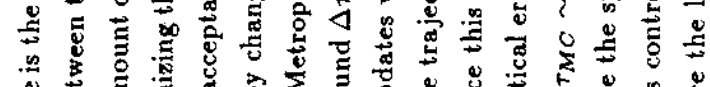

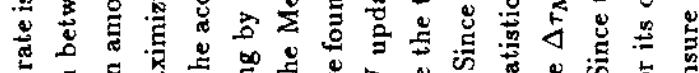

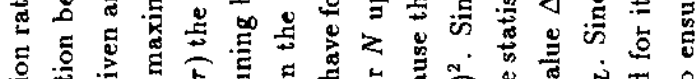

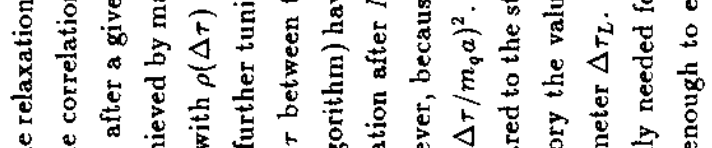

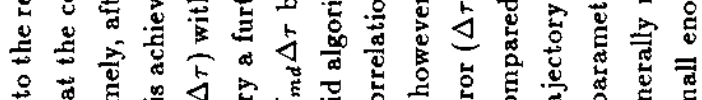

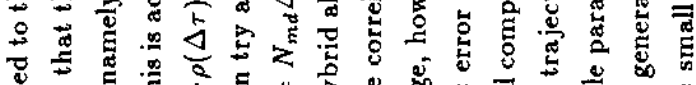

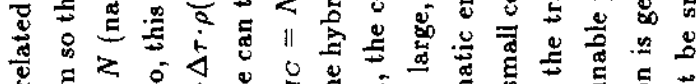

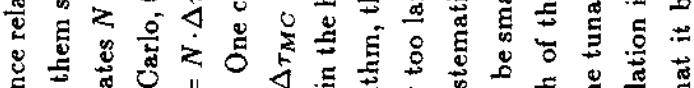

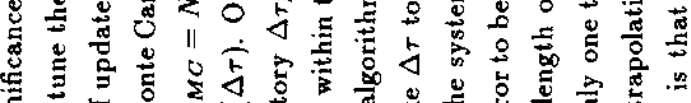

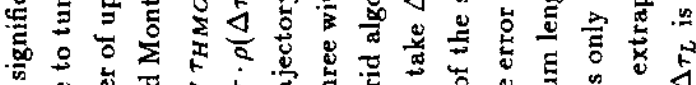

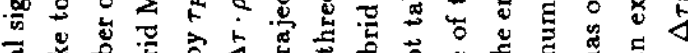

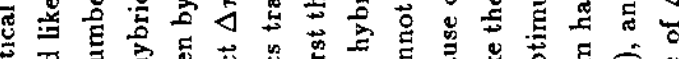

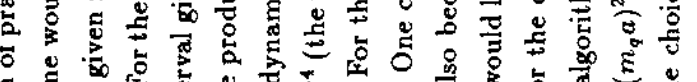

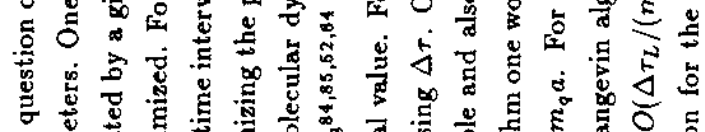

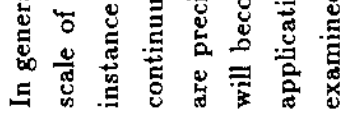

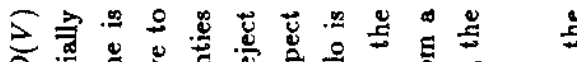

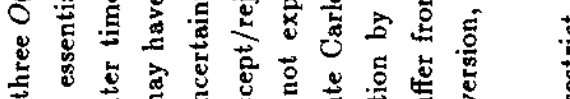

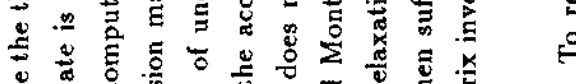

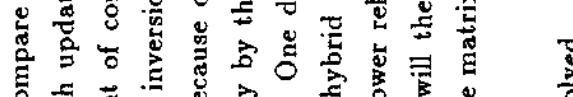

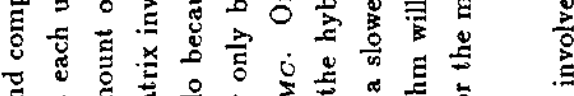

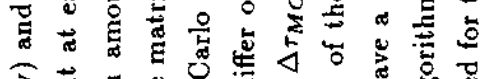

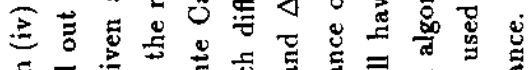

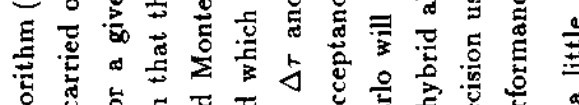

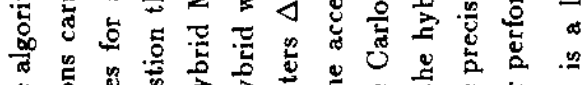

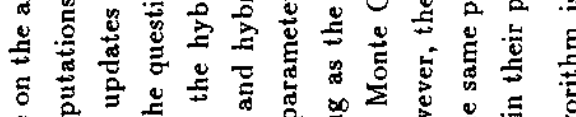

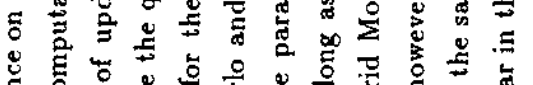

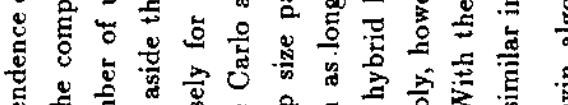

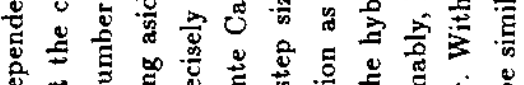

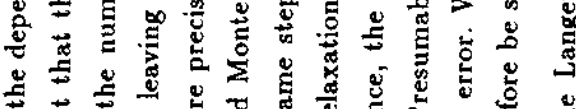

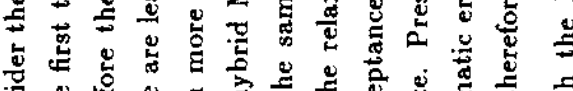

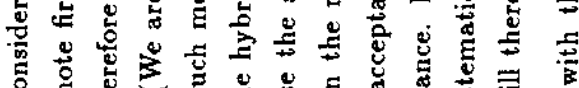
(1) (1) H 3)

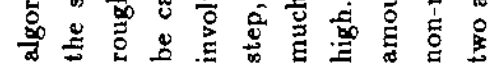

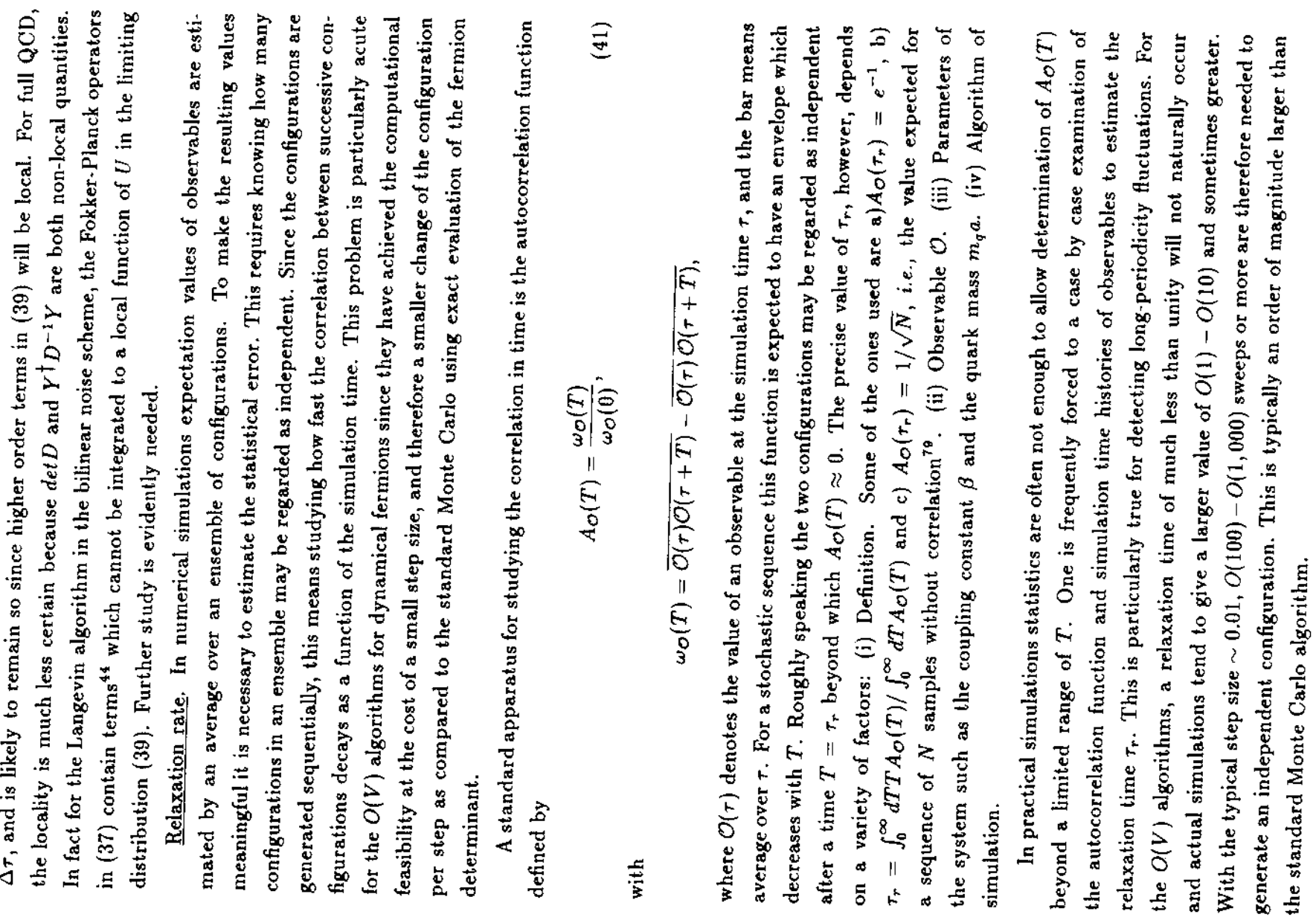




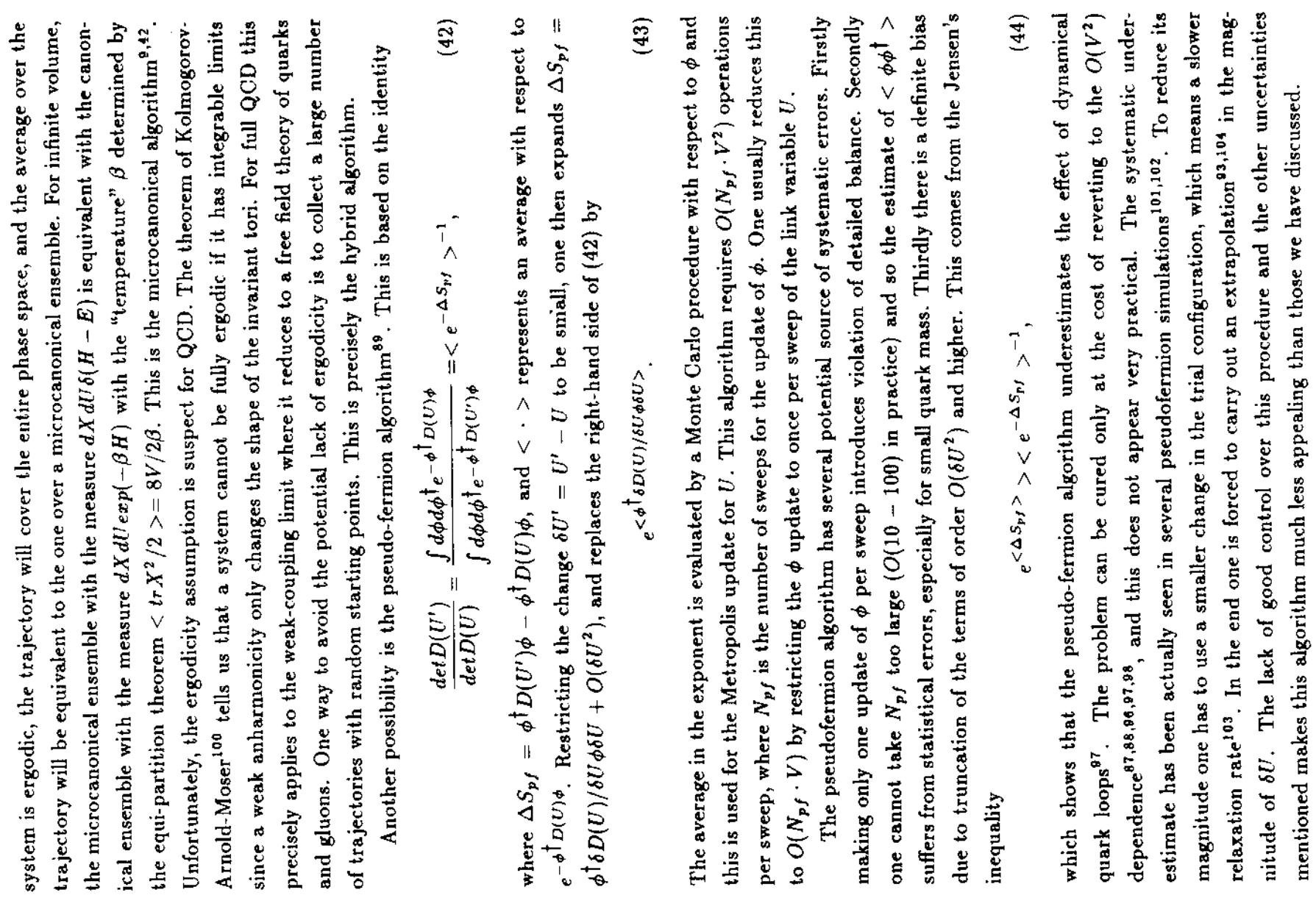

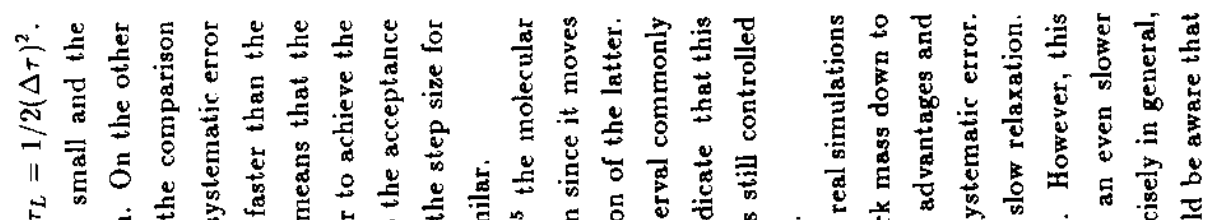

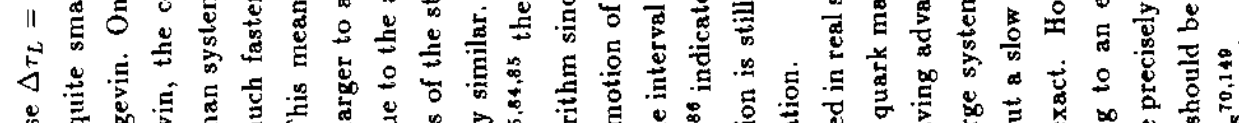

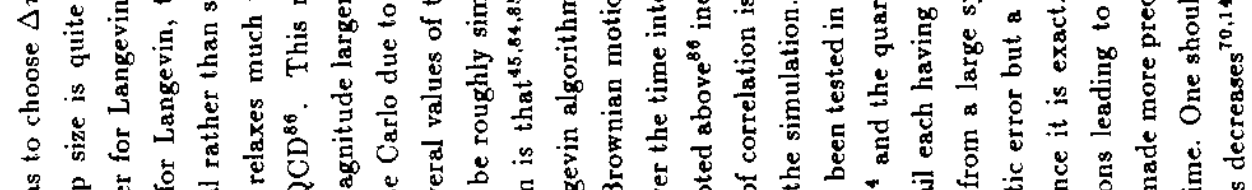

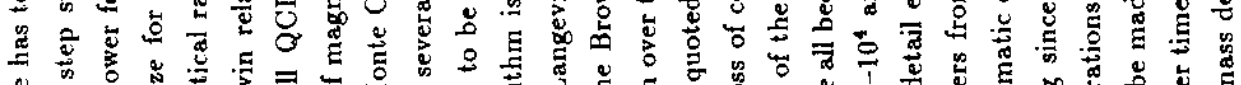

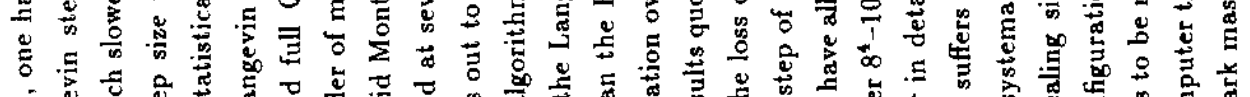

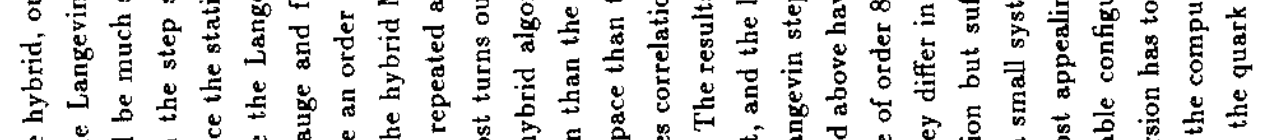
1
$\sim$

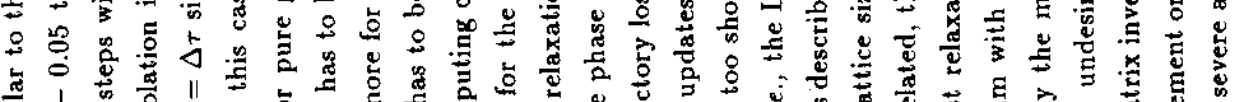

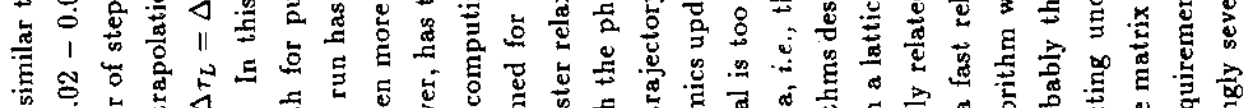

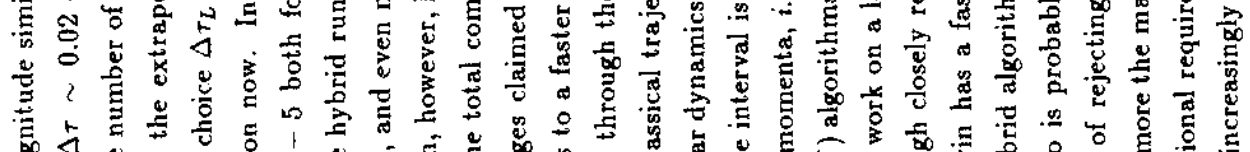

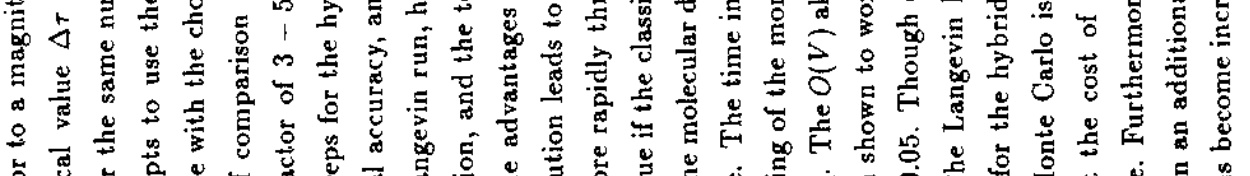

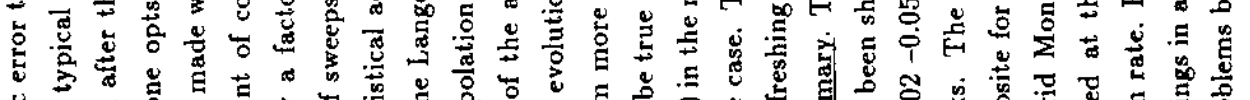

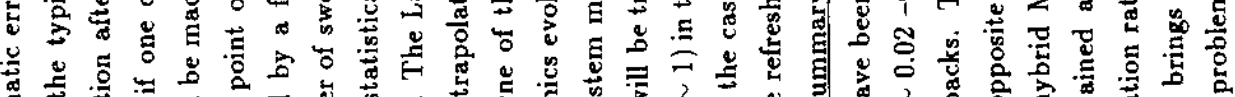

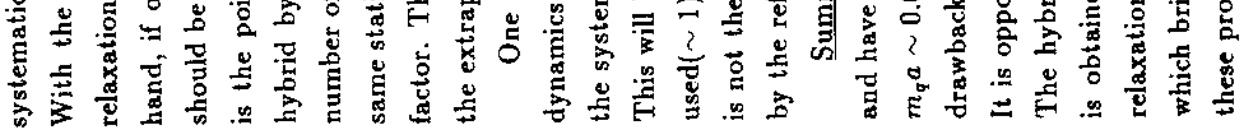

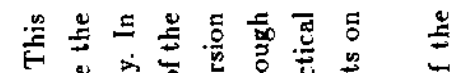

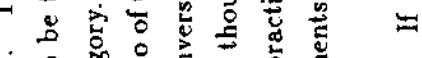

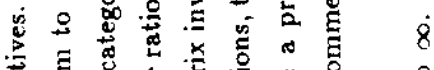

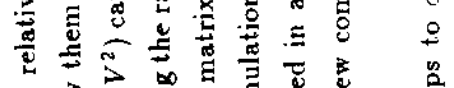

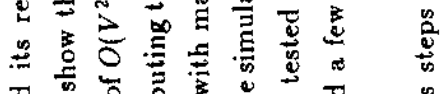

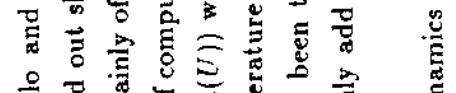

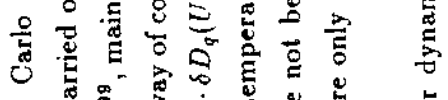

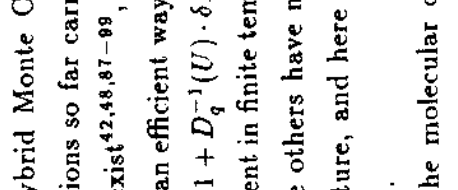

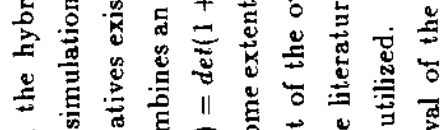
5 क

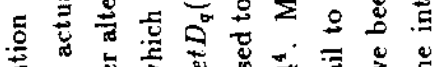

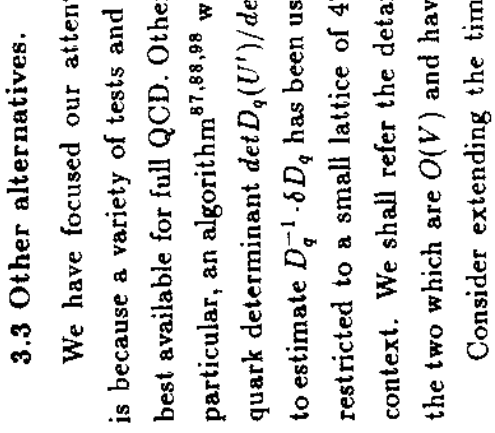



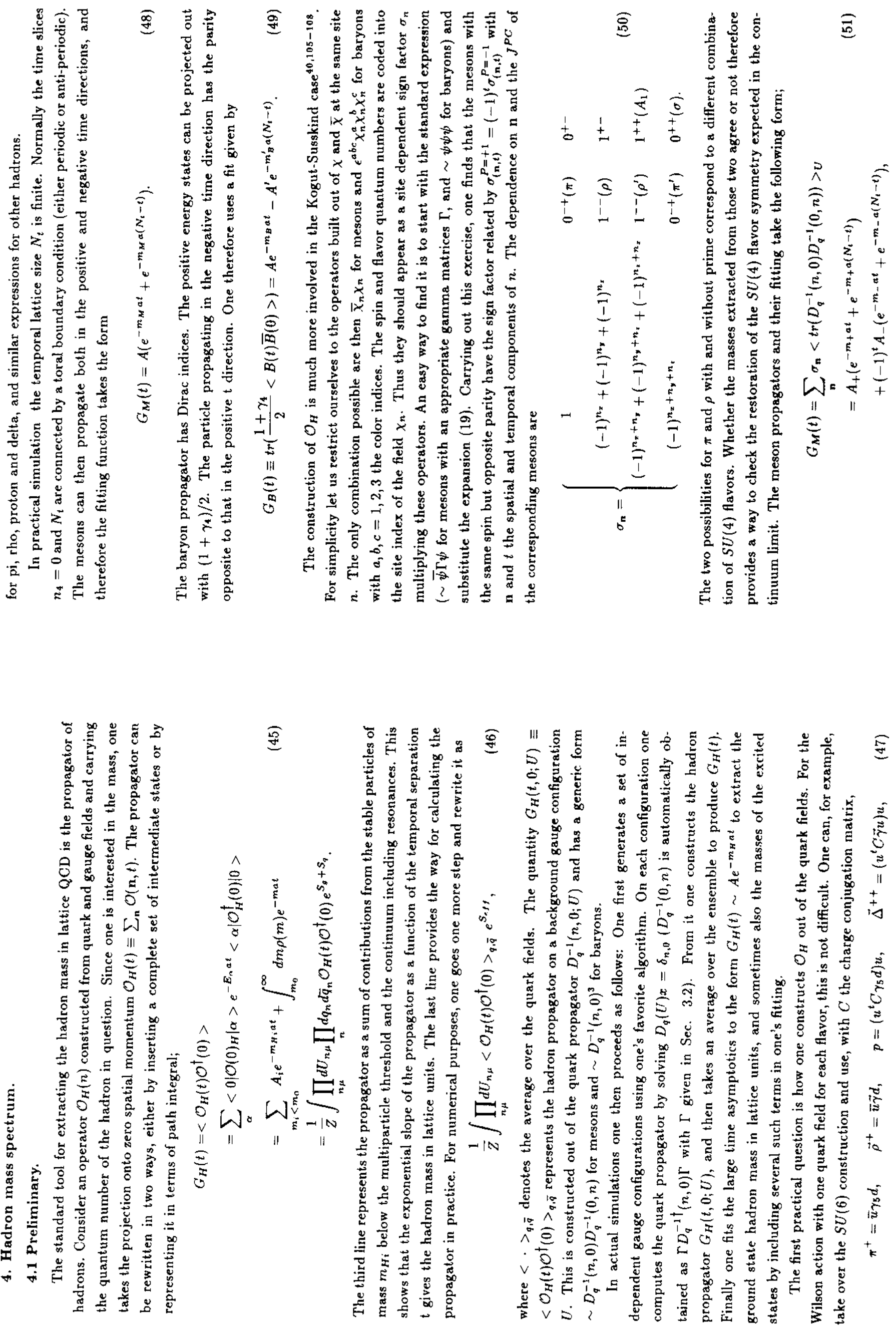


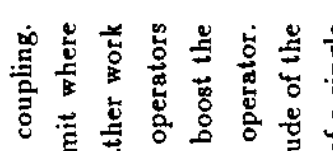

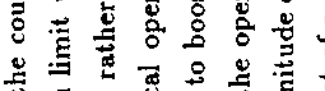

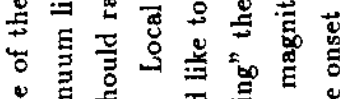

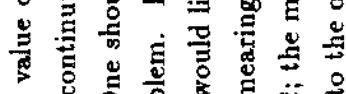

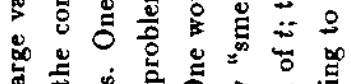

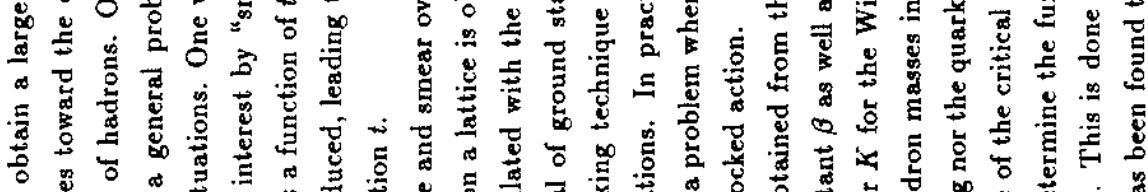

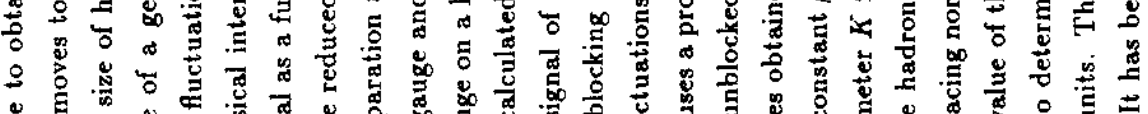

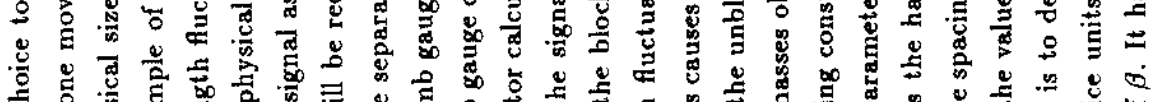

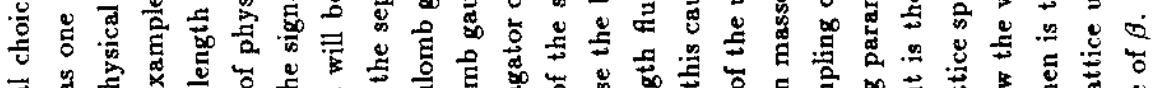

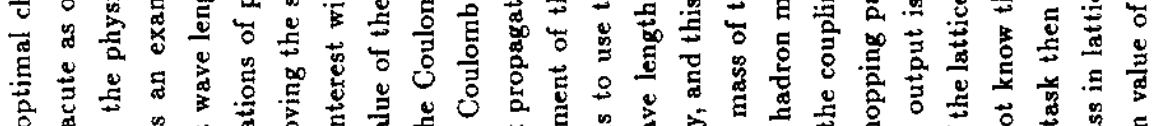

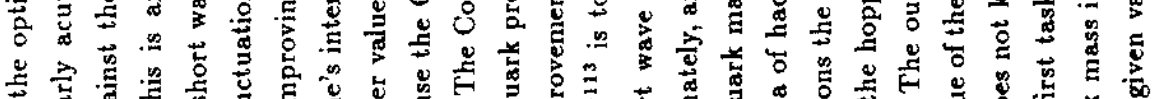

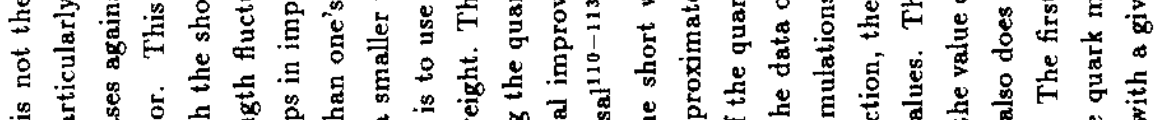

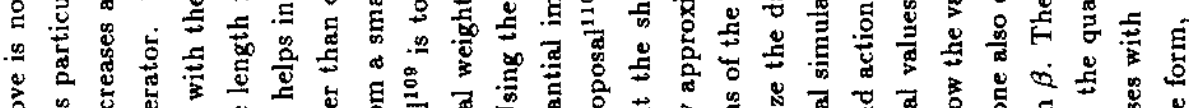

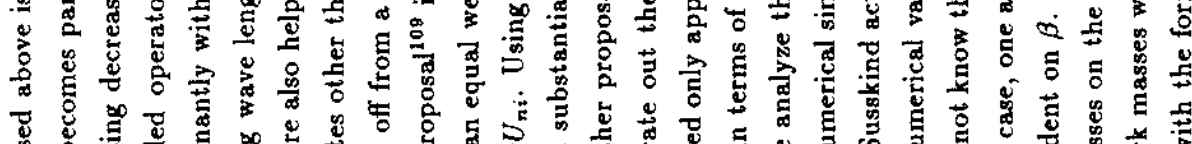

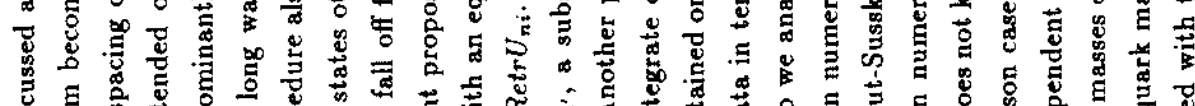

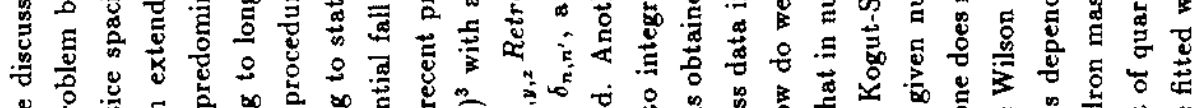

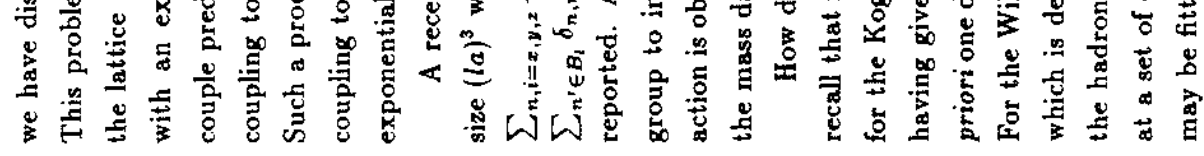

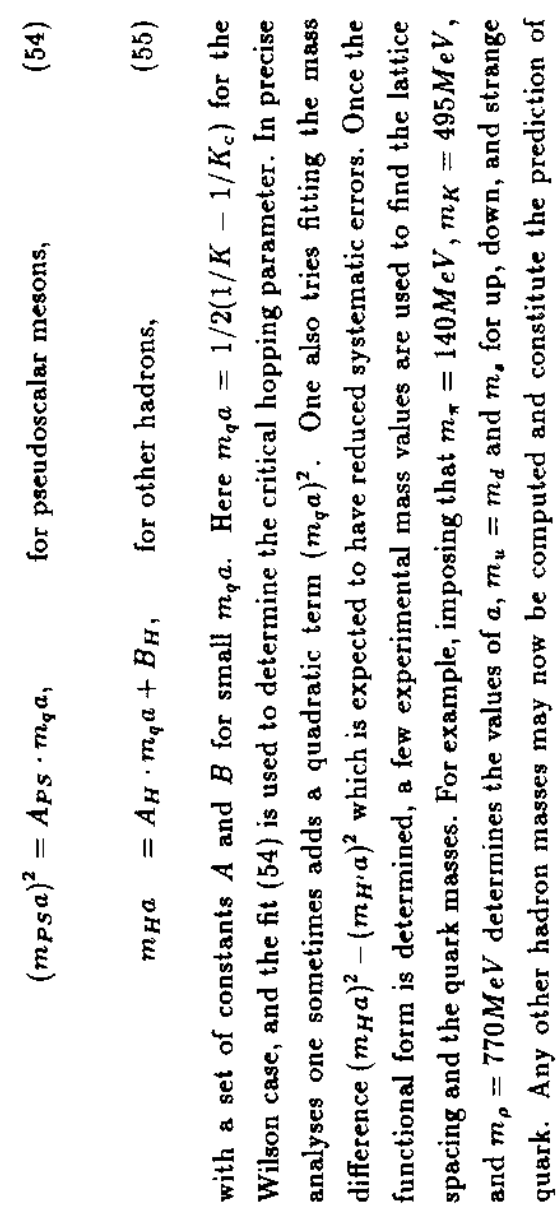

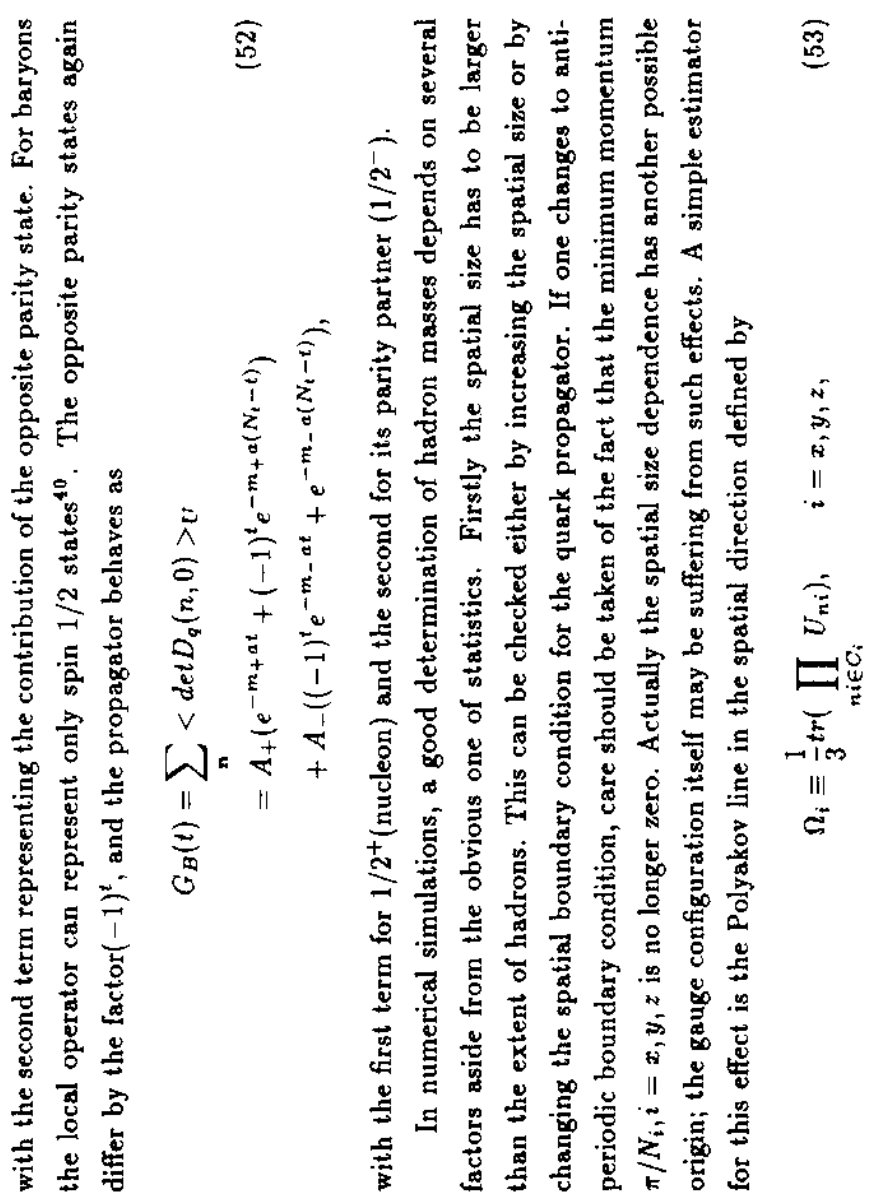

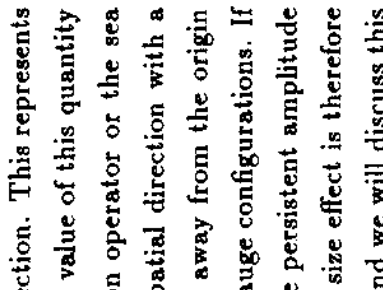

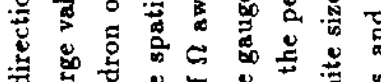

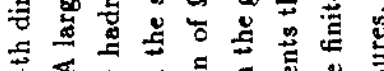

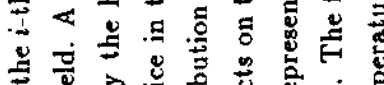

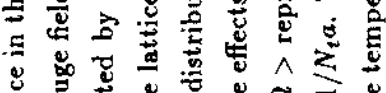

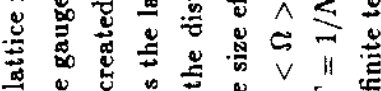

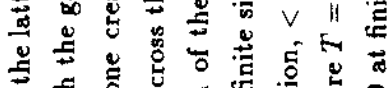

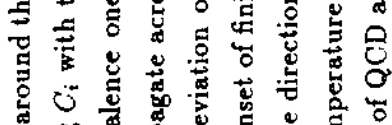

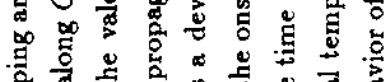

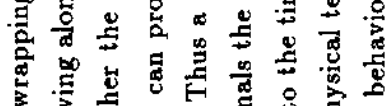

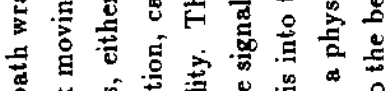

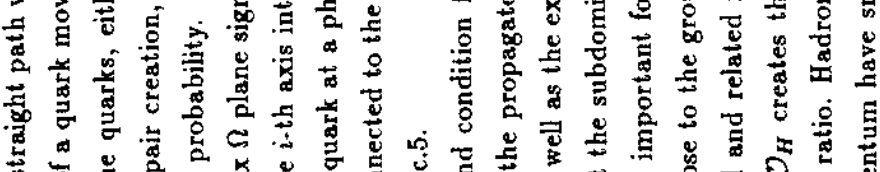

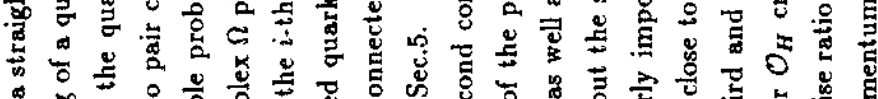

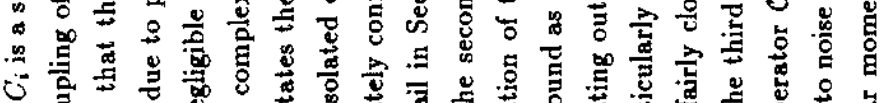

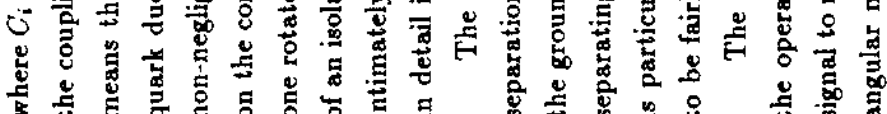




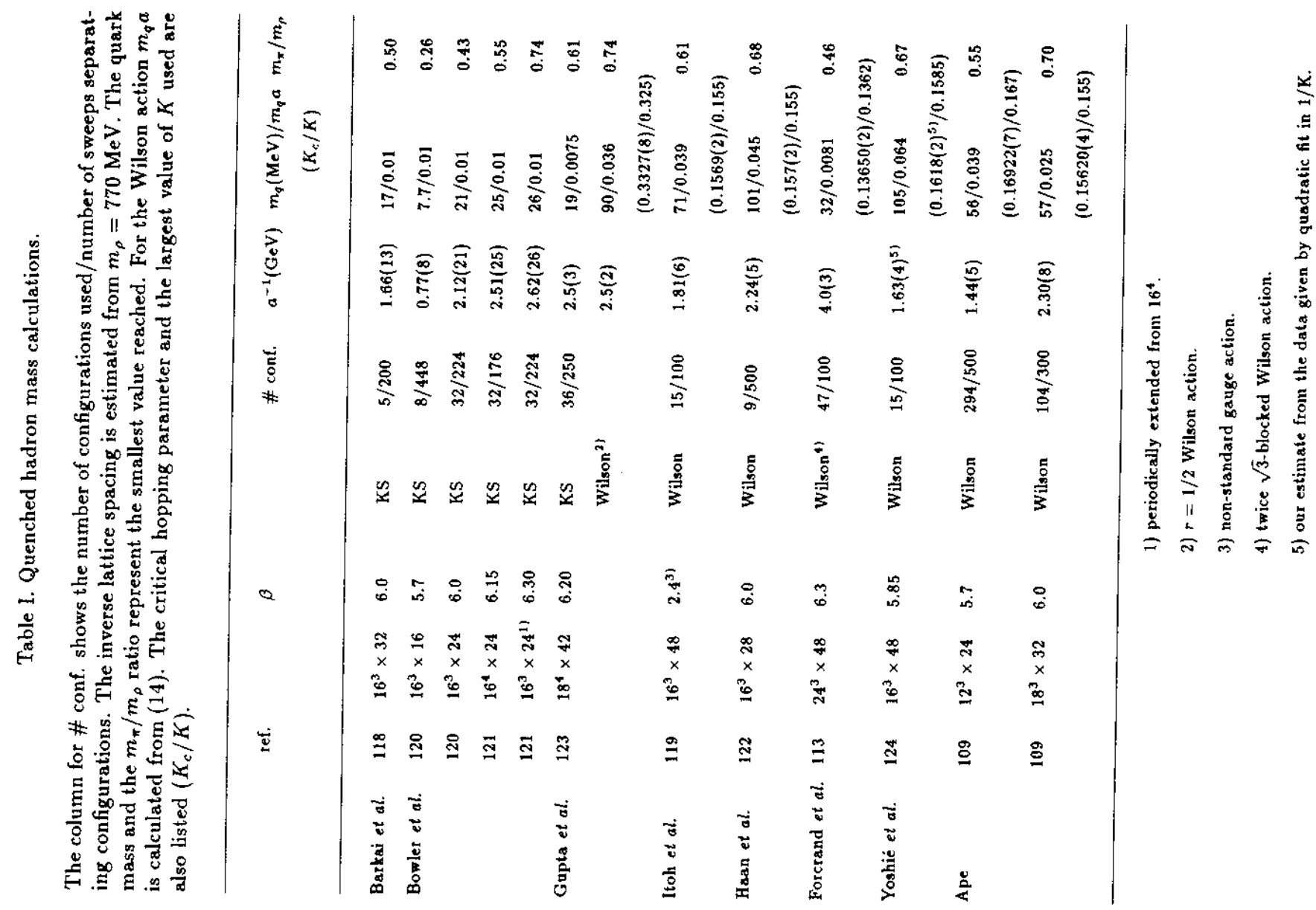

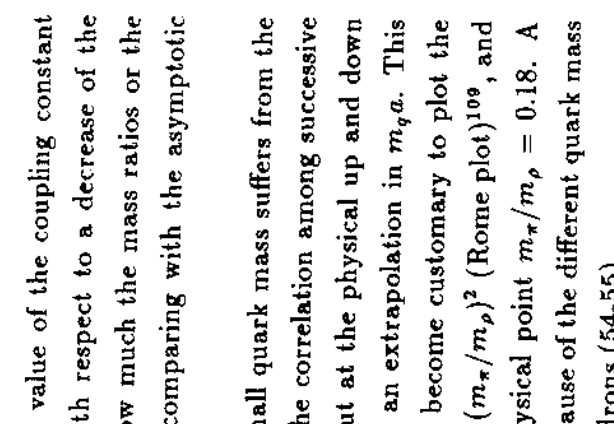

H In In m 1 II

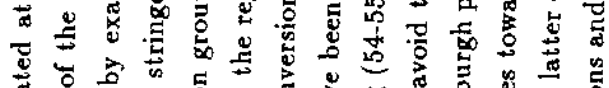
ming MIIIII InIn

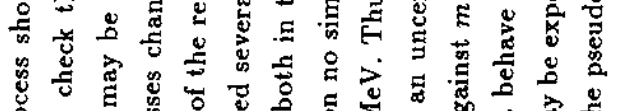

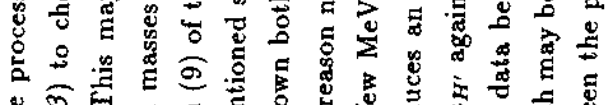
Int minthy minth

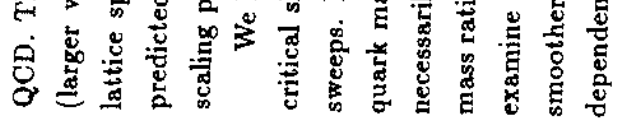

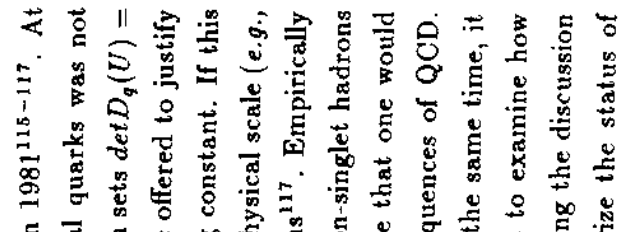
min IIIIIII

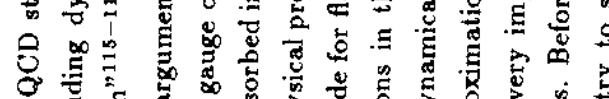
HIIIIIIII II $M M I I$

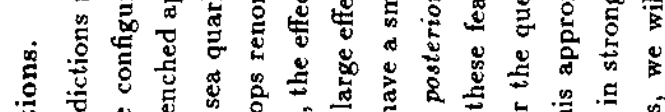

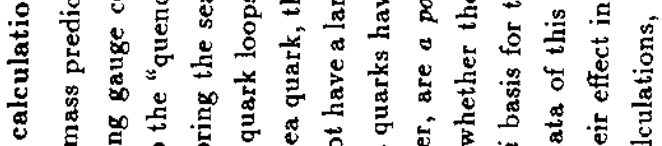
过

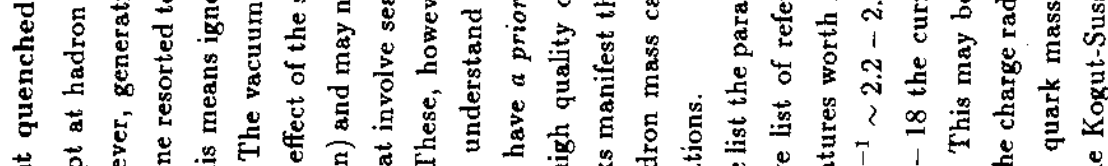

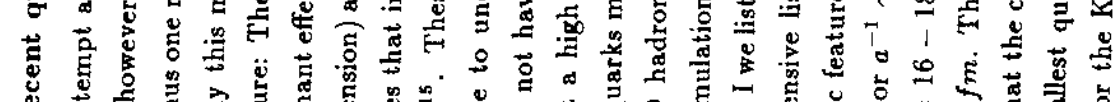

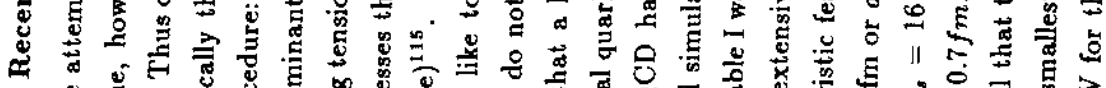
广

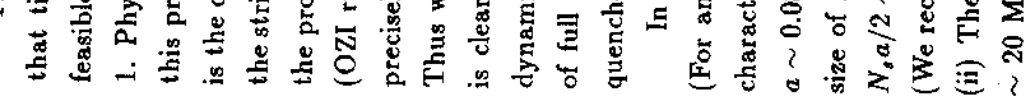




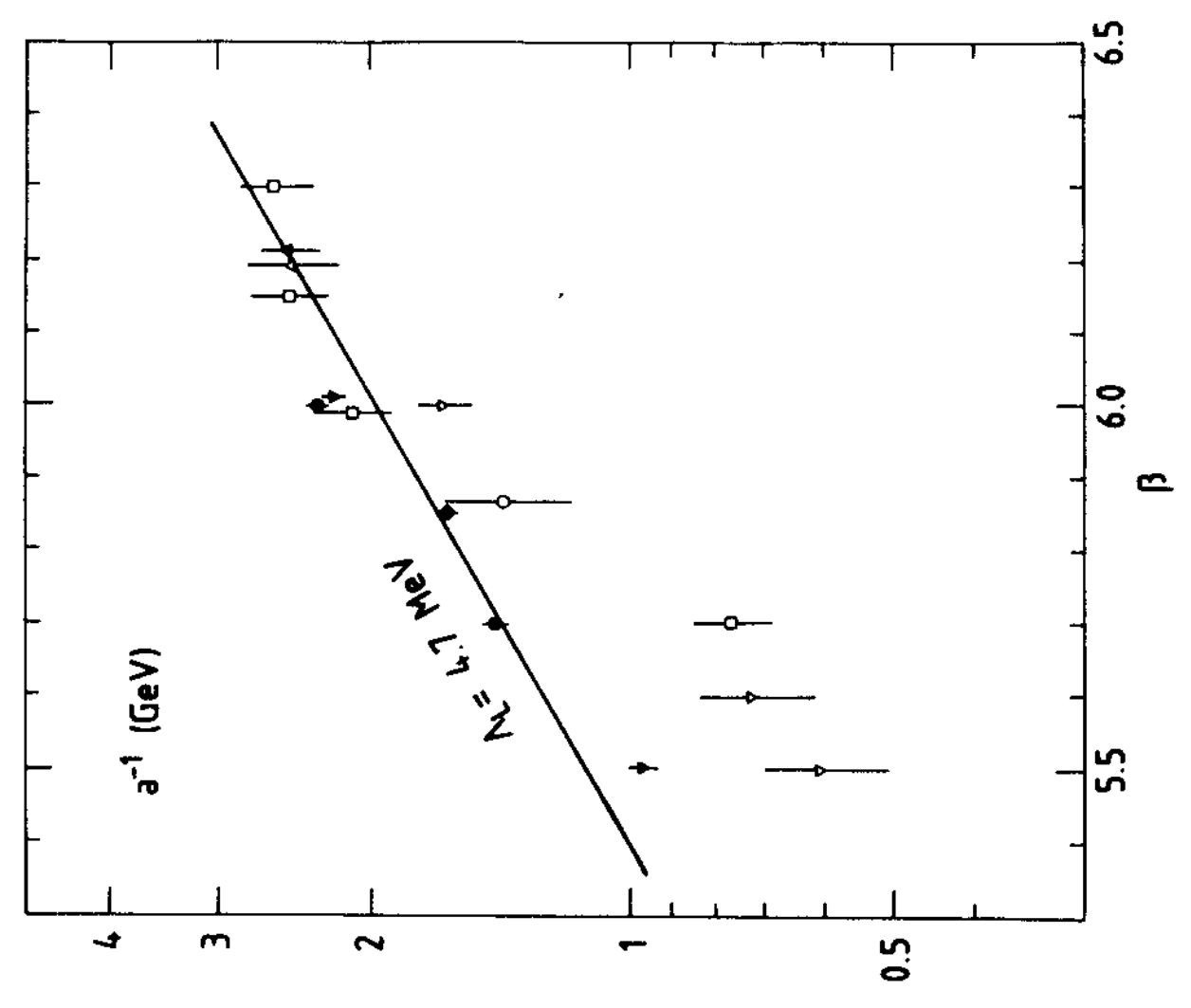

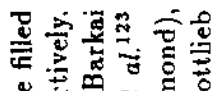

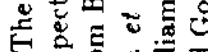

>

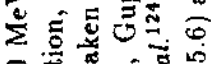

옹

है

ए

要

चै

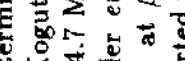

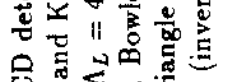

要金

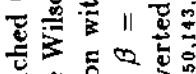

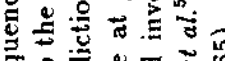

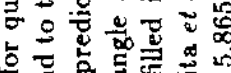

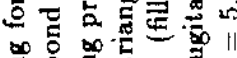

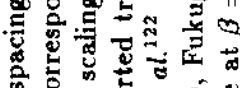

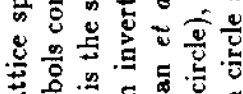

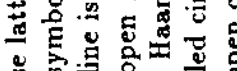

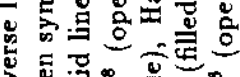

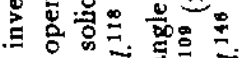

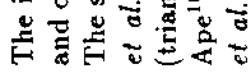

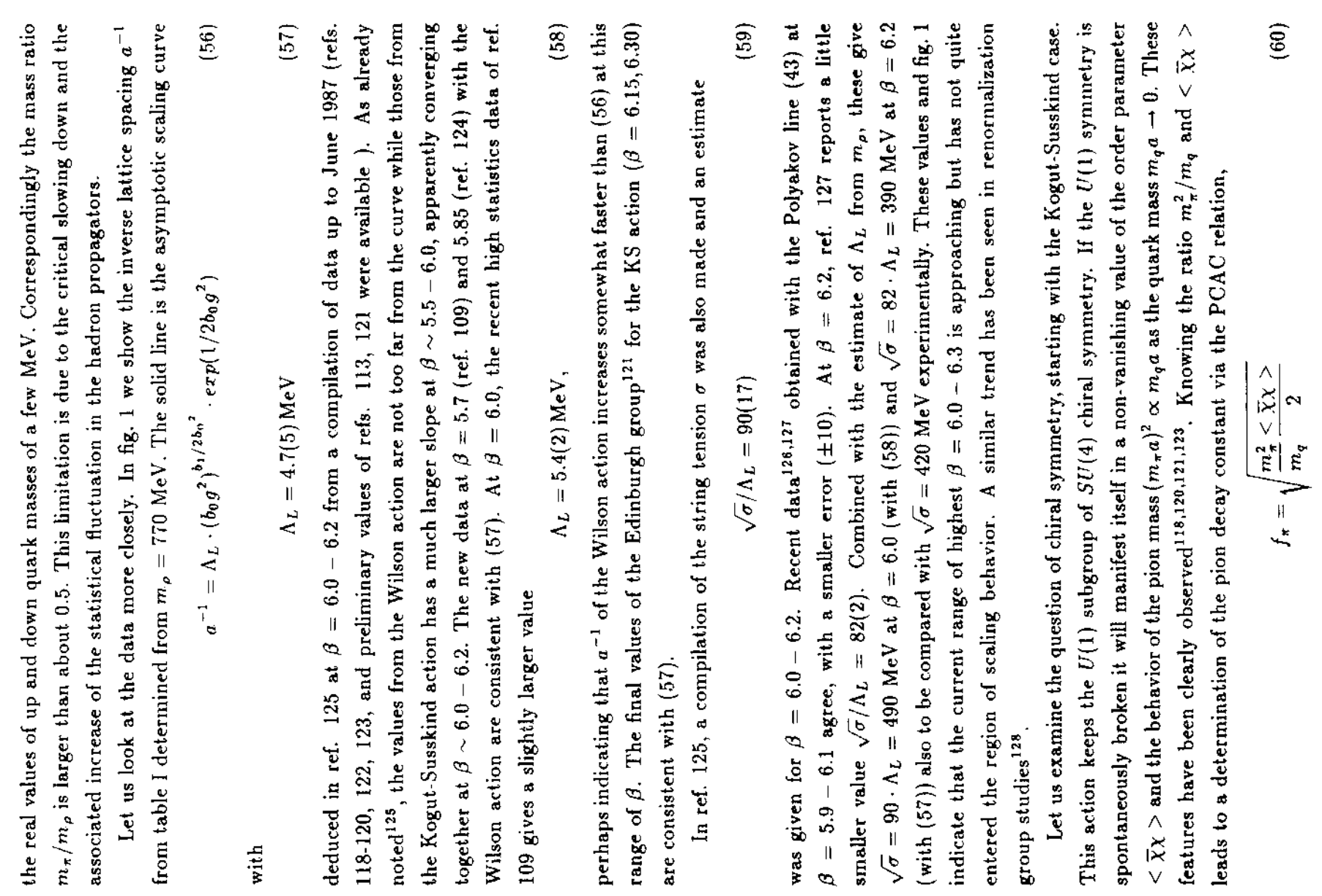




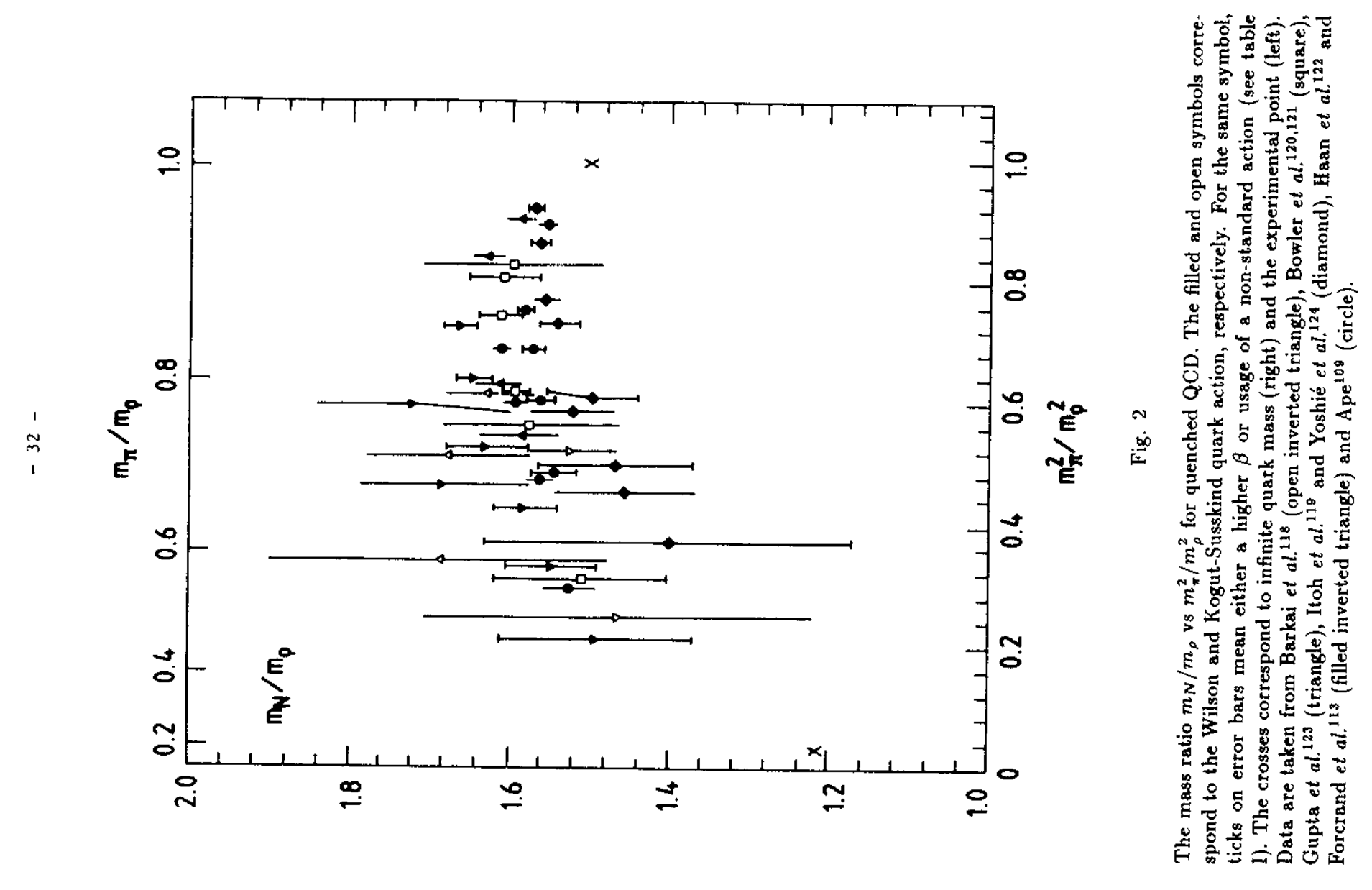

袋

sim

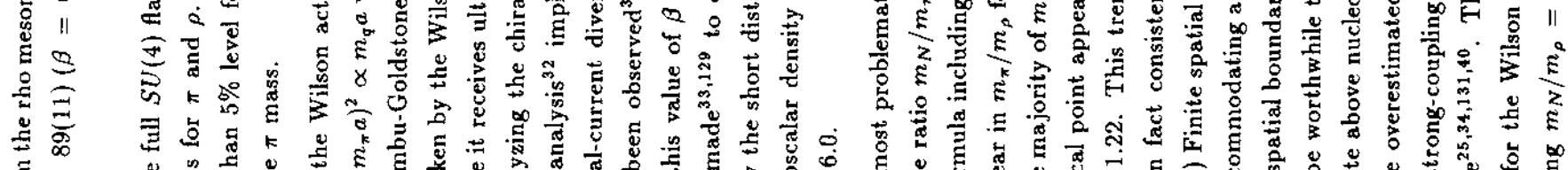

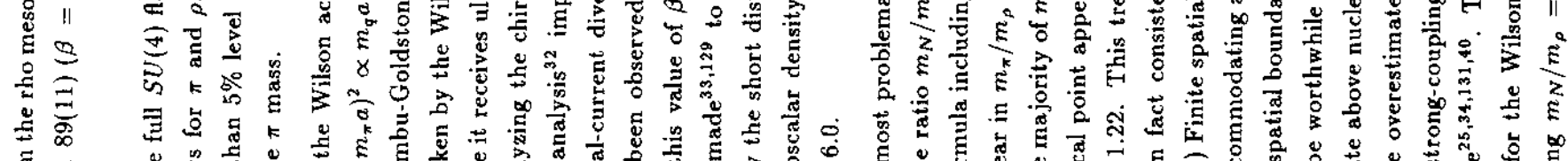

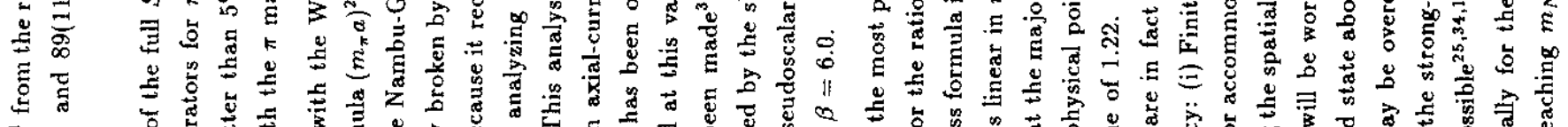

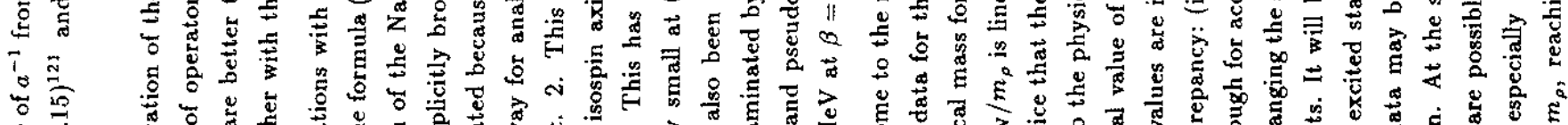

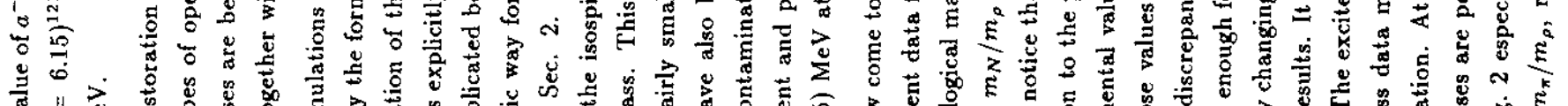
IXI)

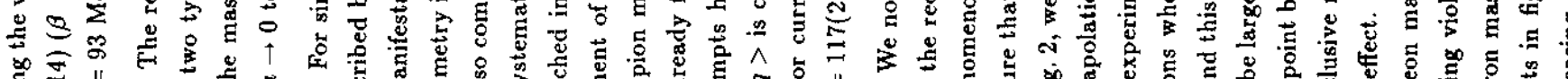

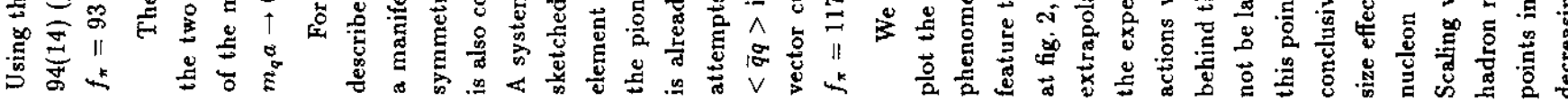




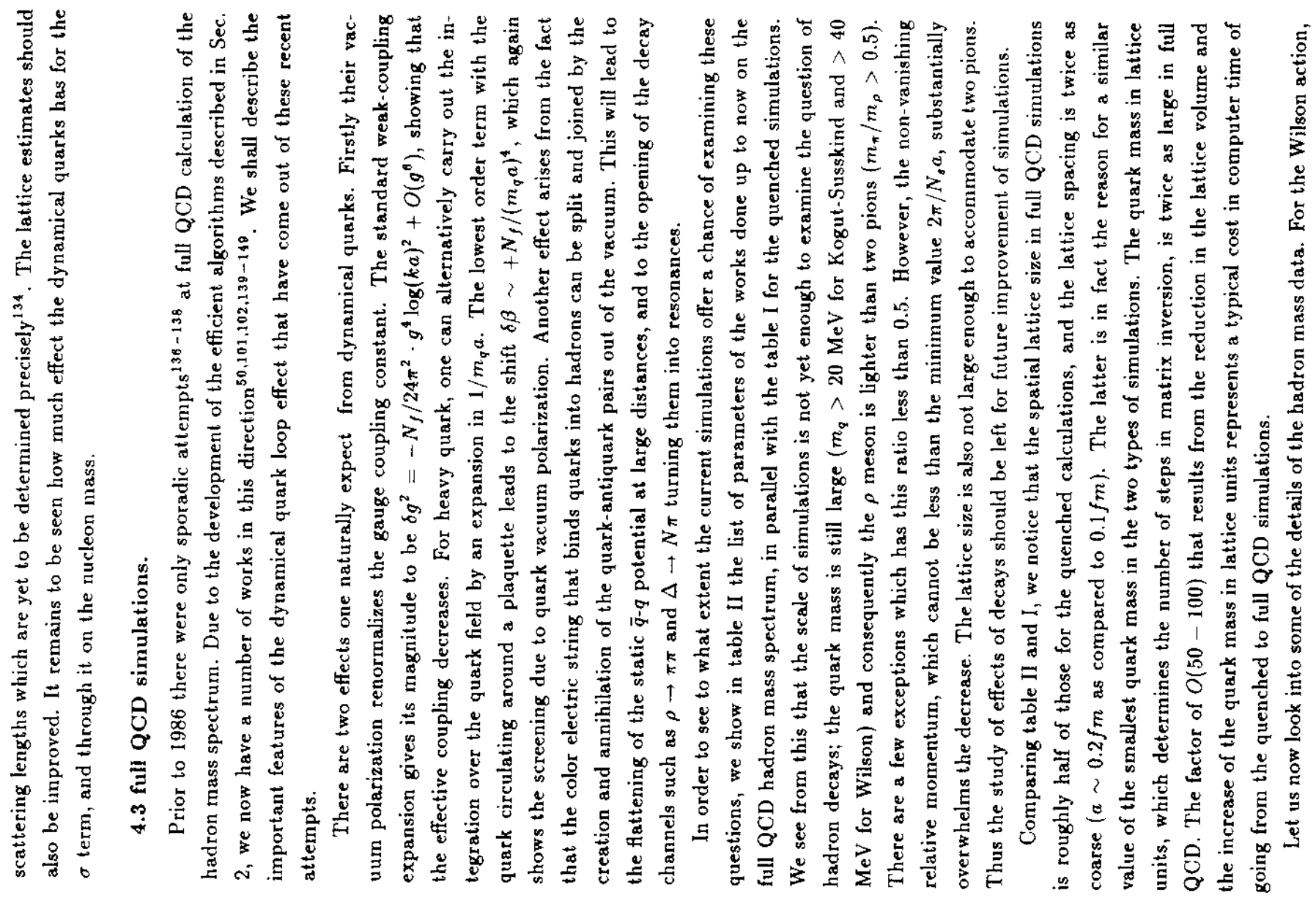

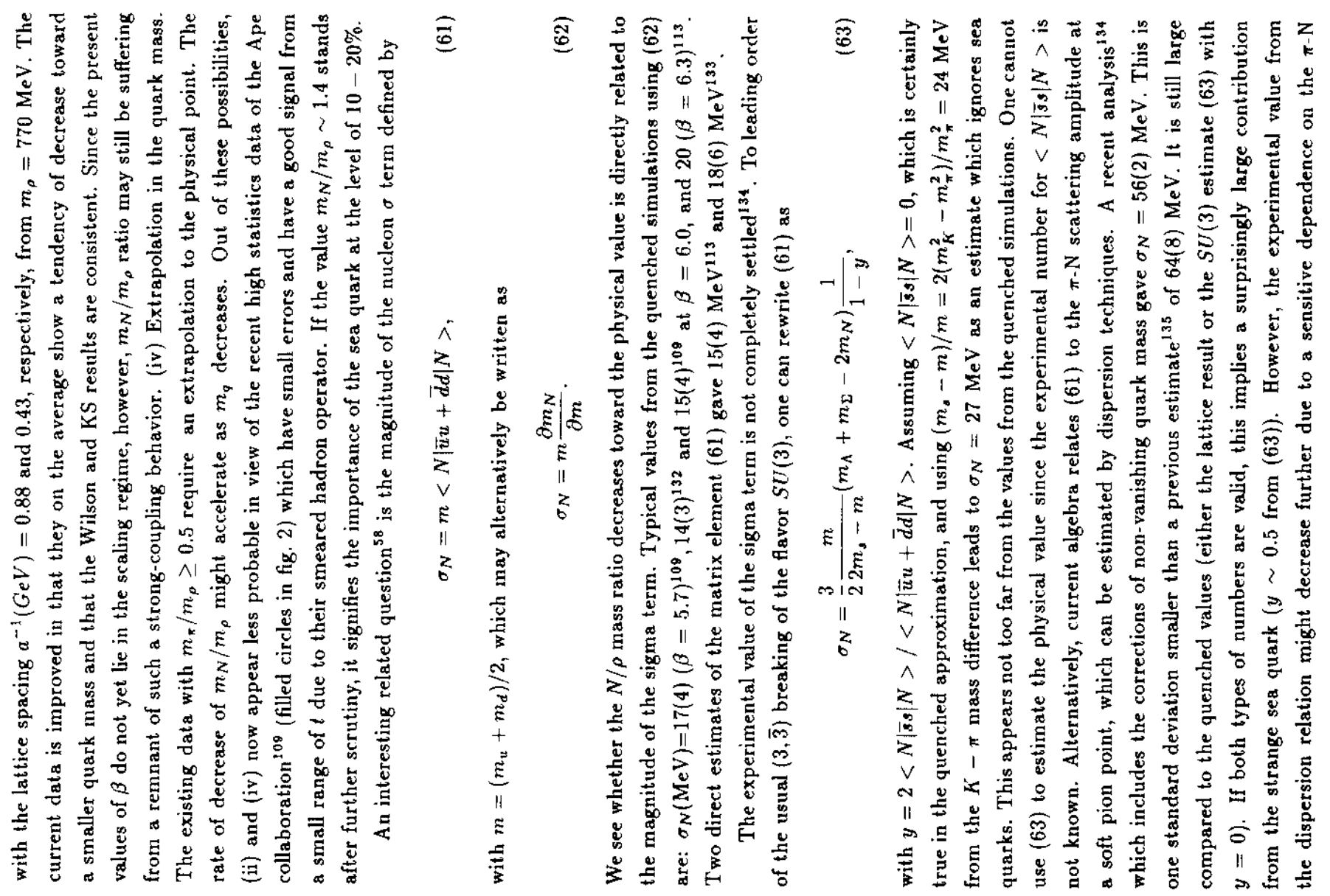




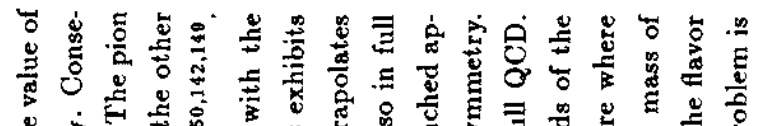

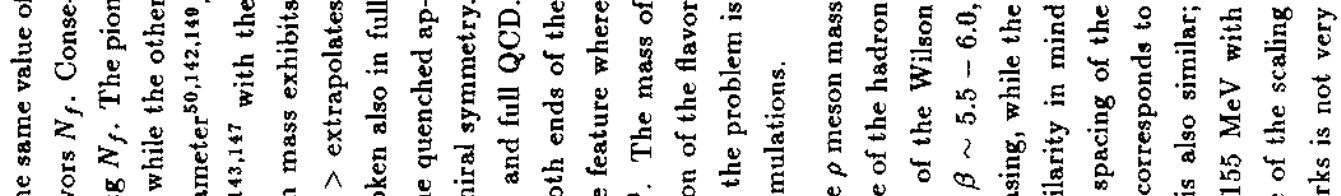

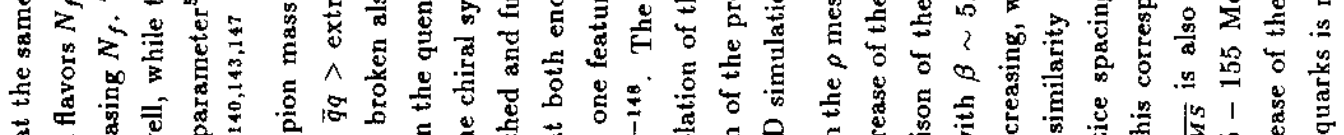

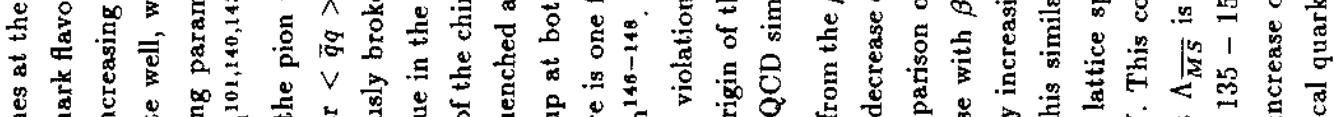

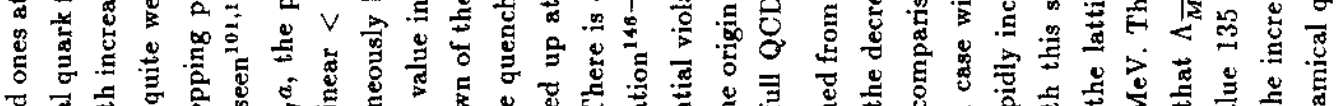

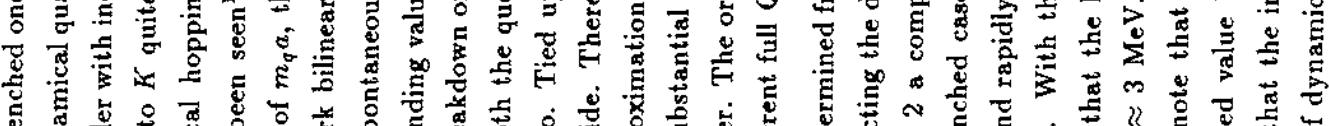

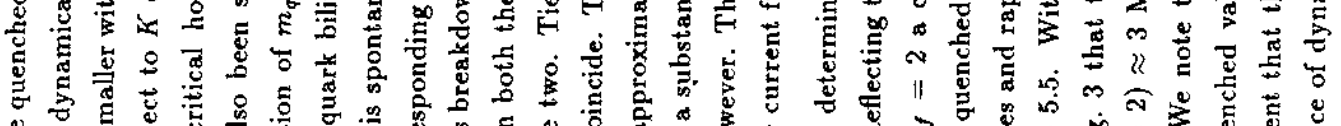

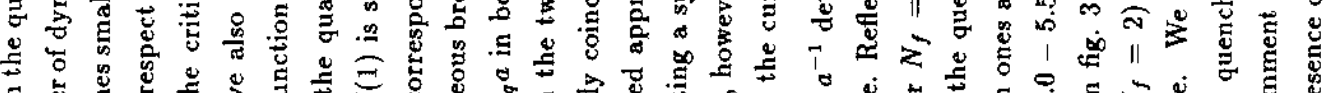

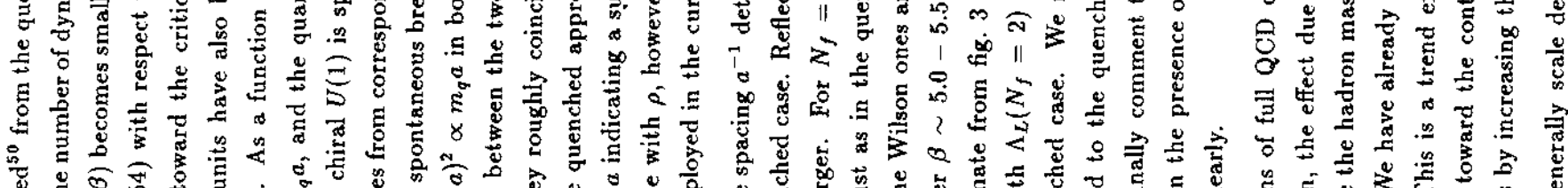

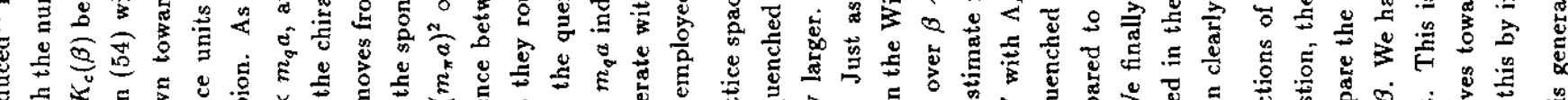

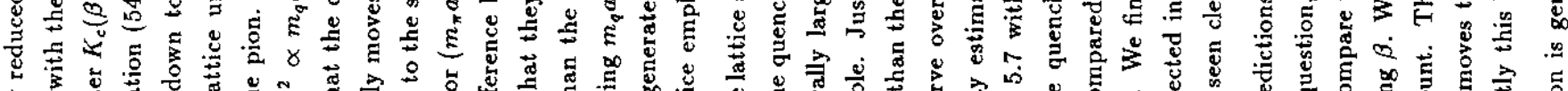

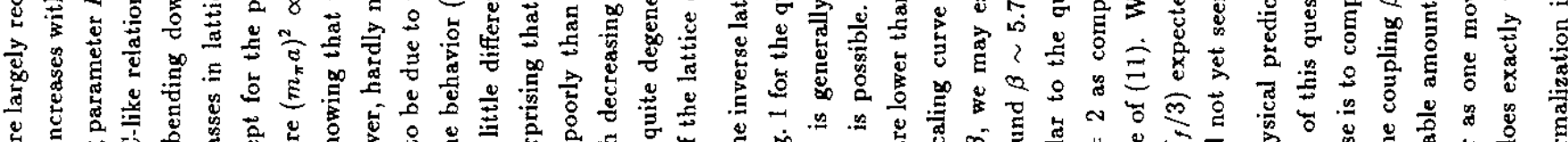

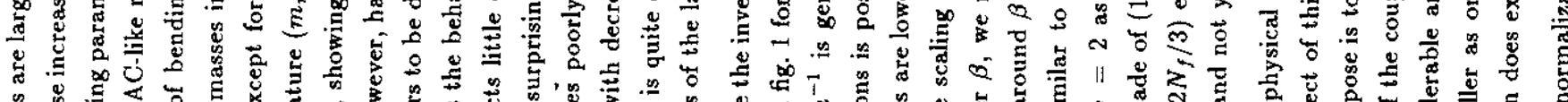

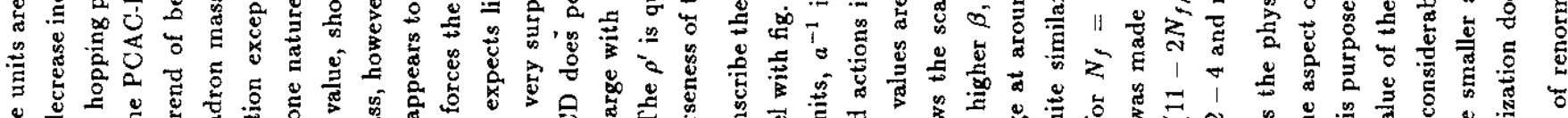

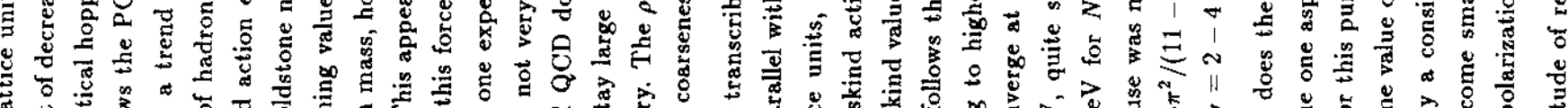

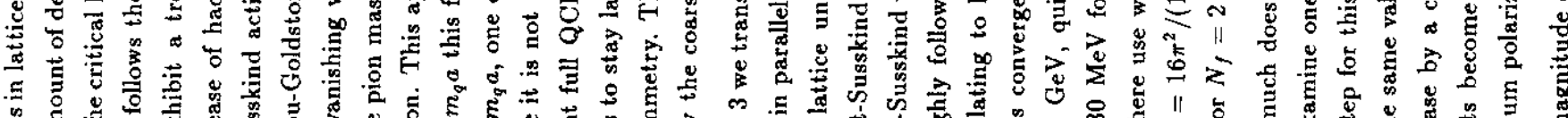

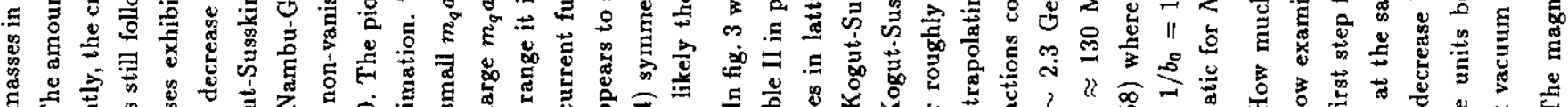

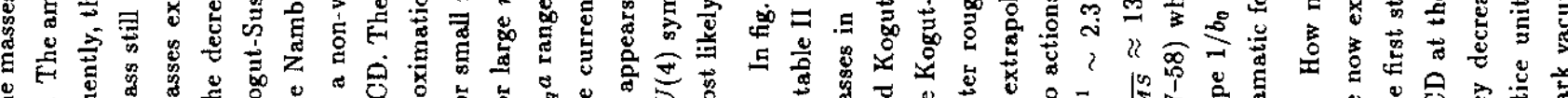

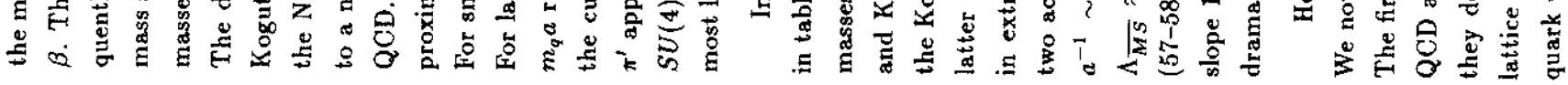

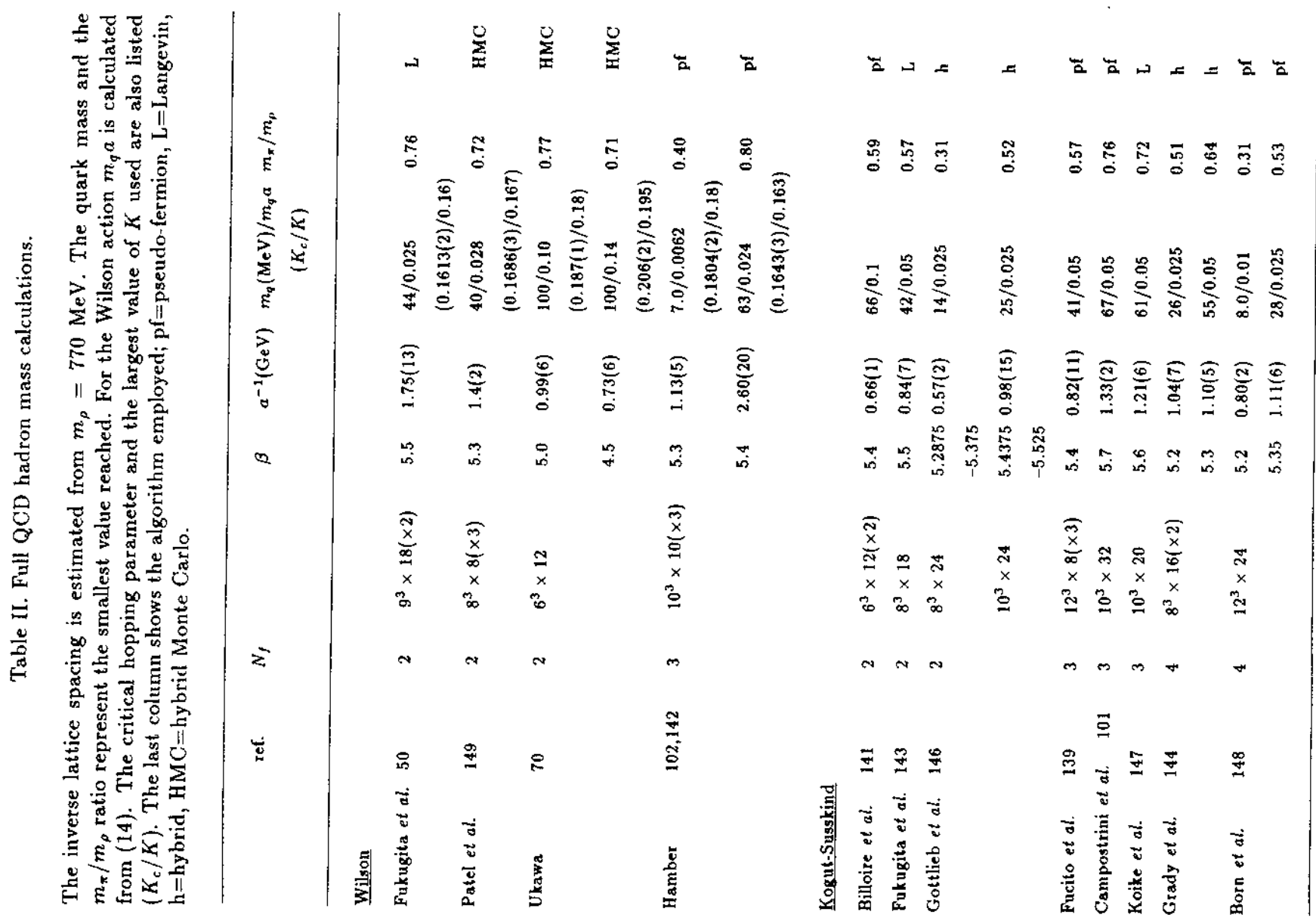




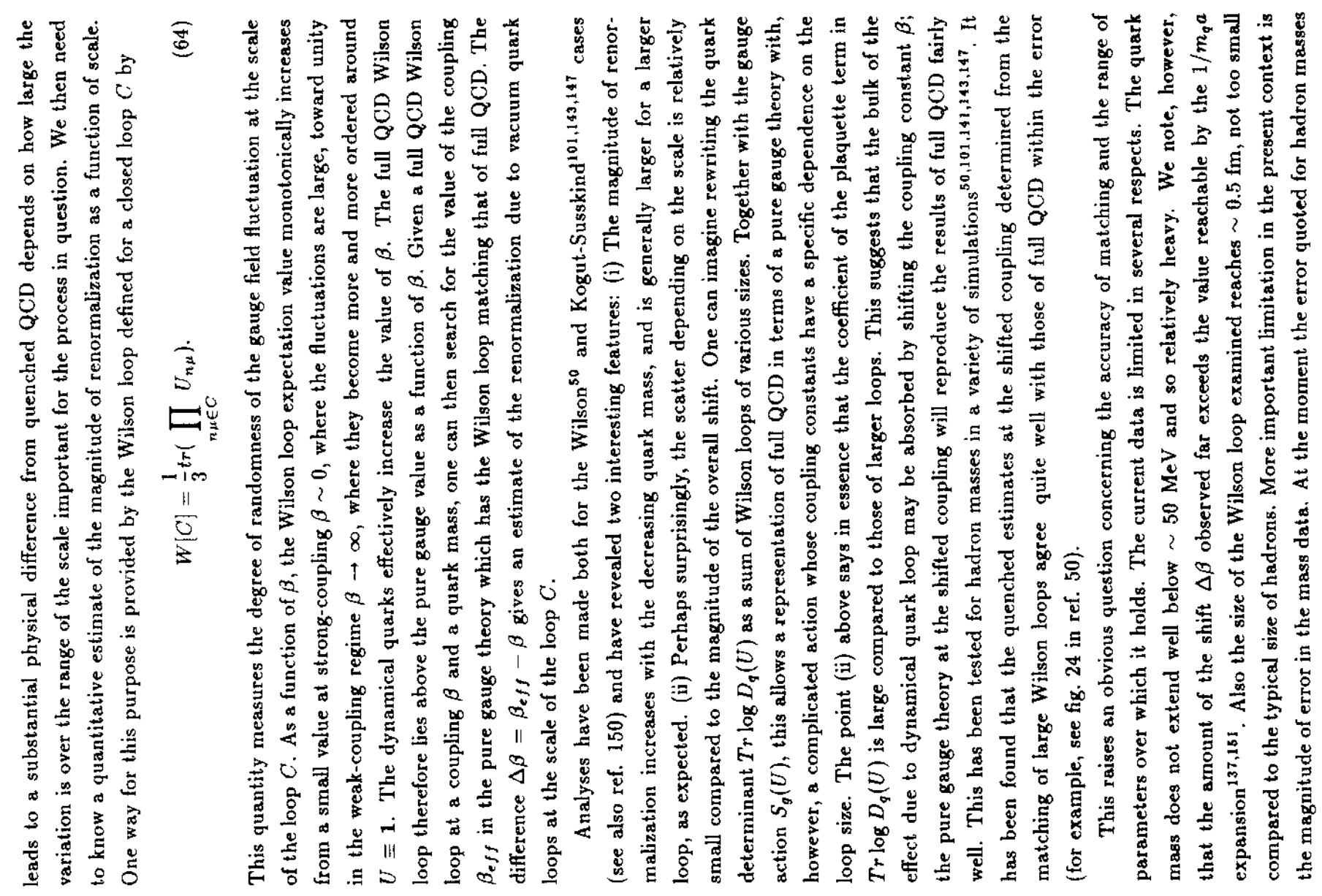

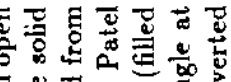

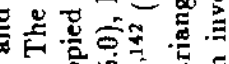

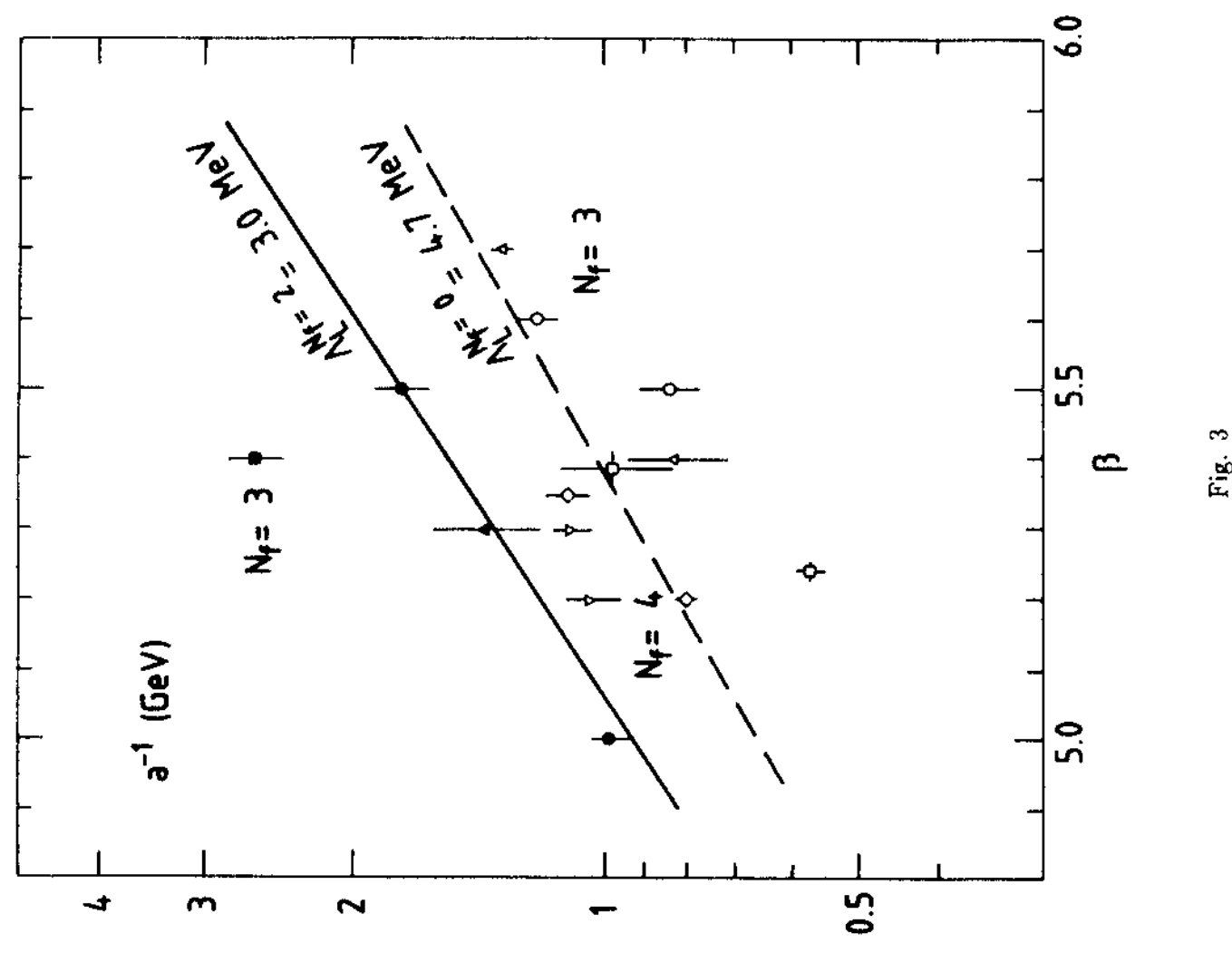

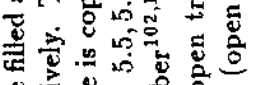

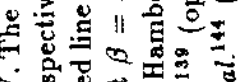

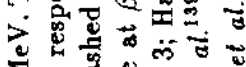

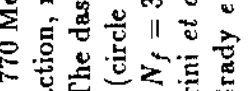

II

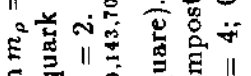

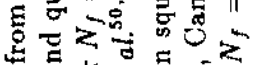

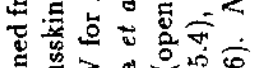

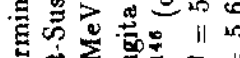

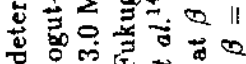

11

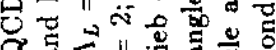

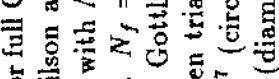

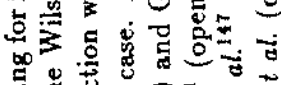

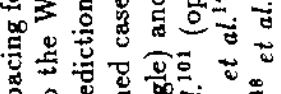

क人

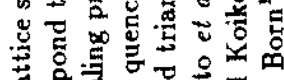

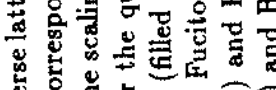

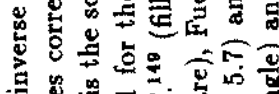

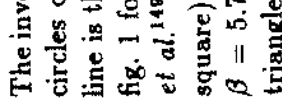




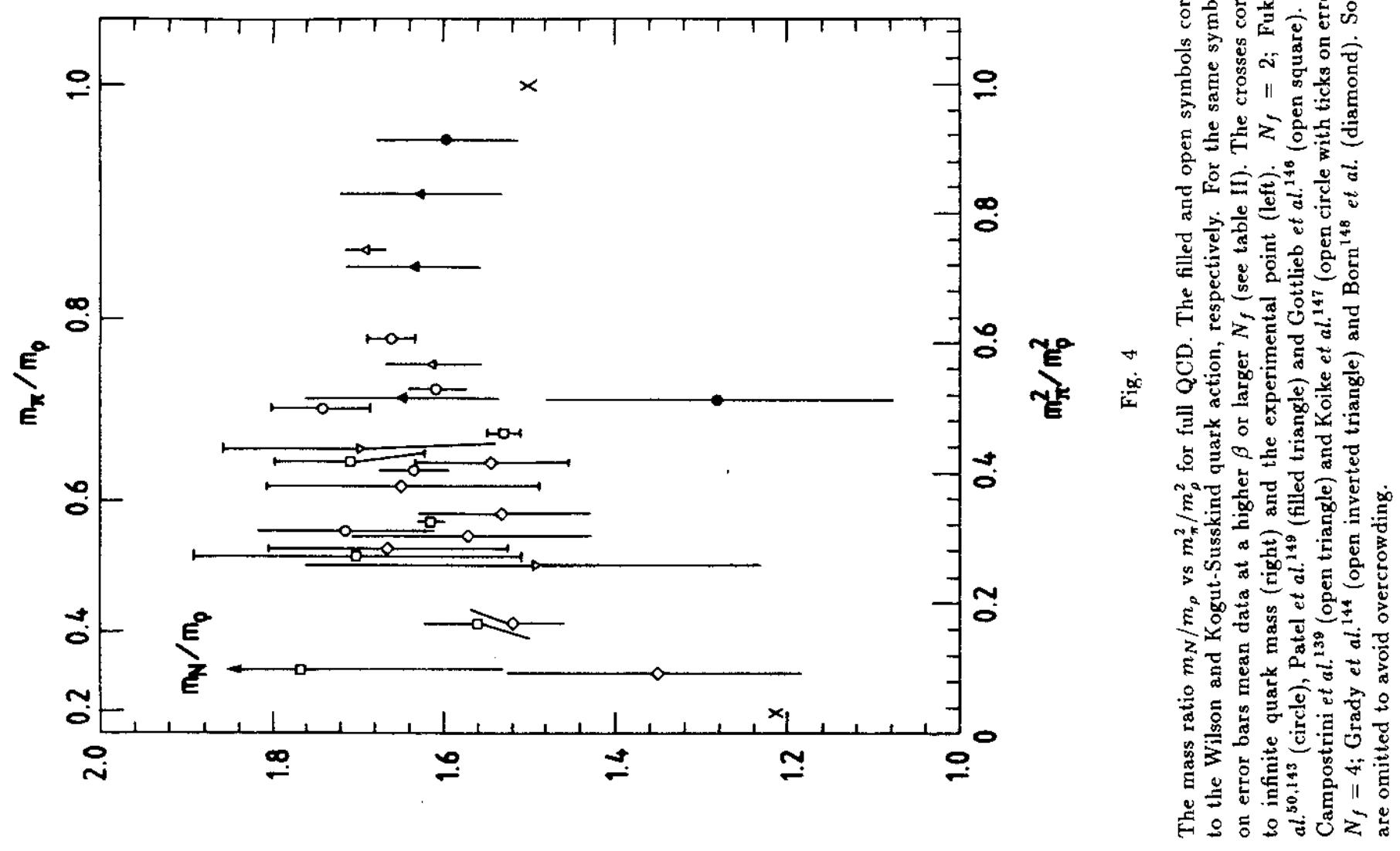

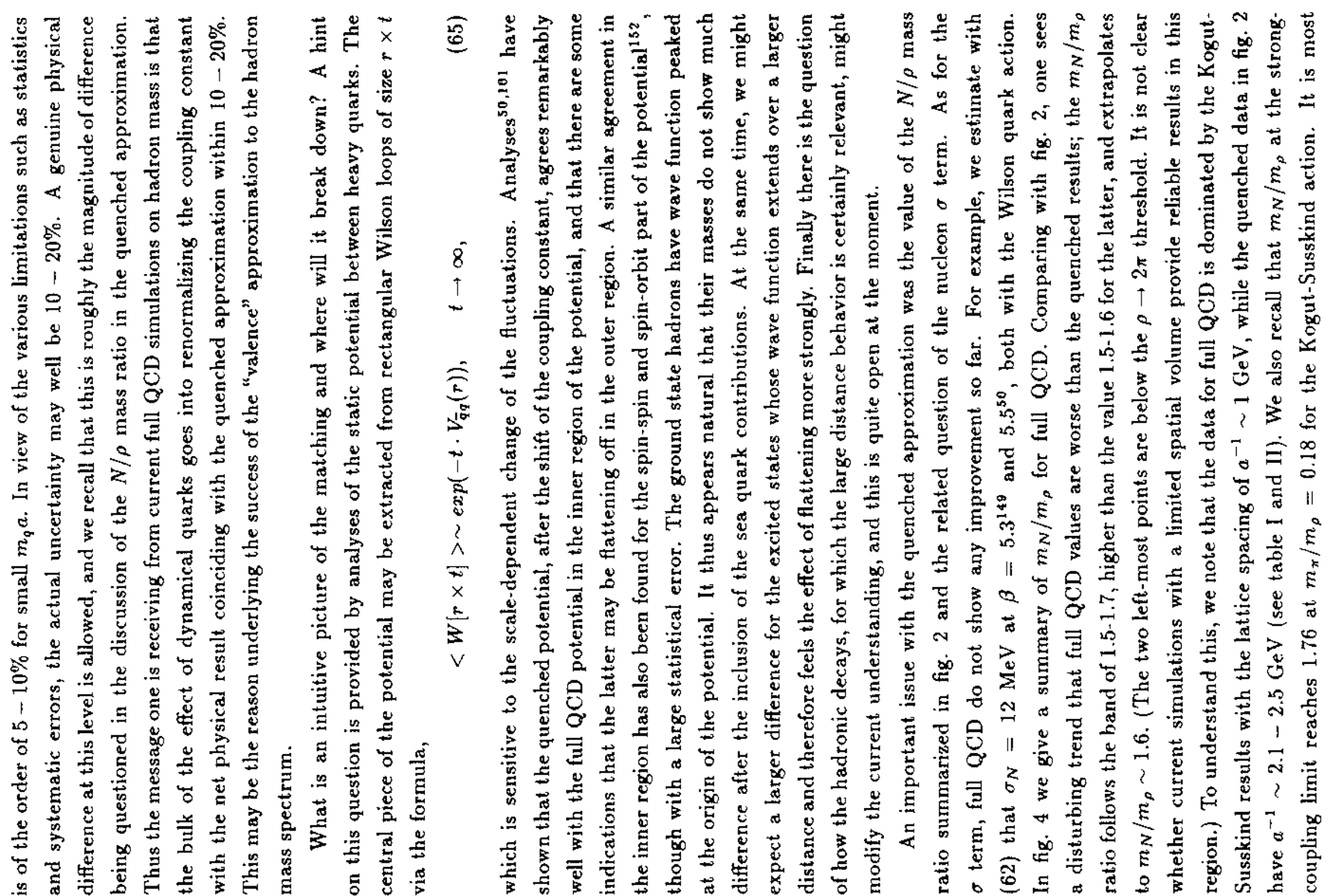



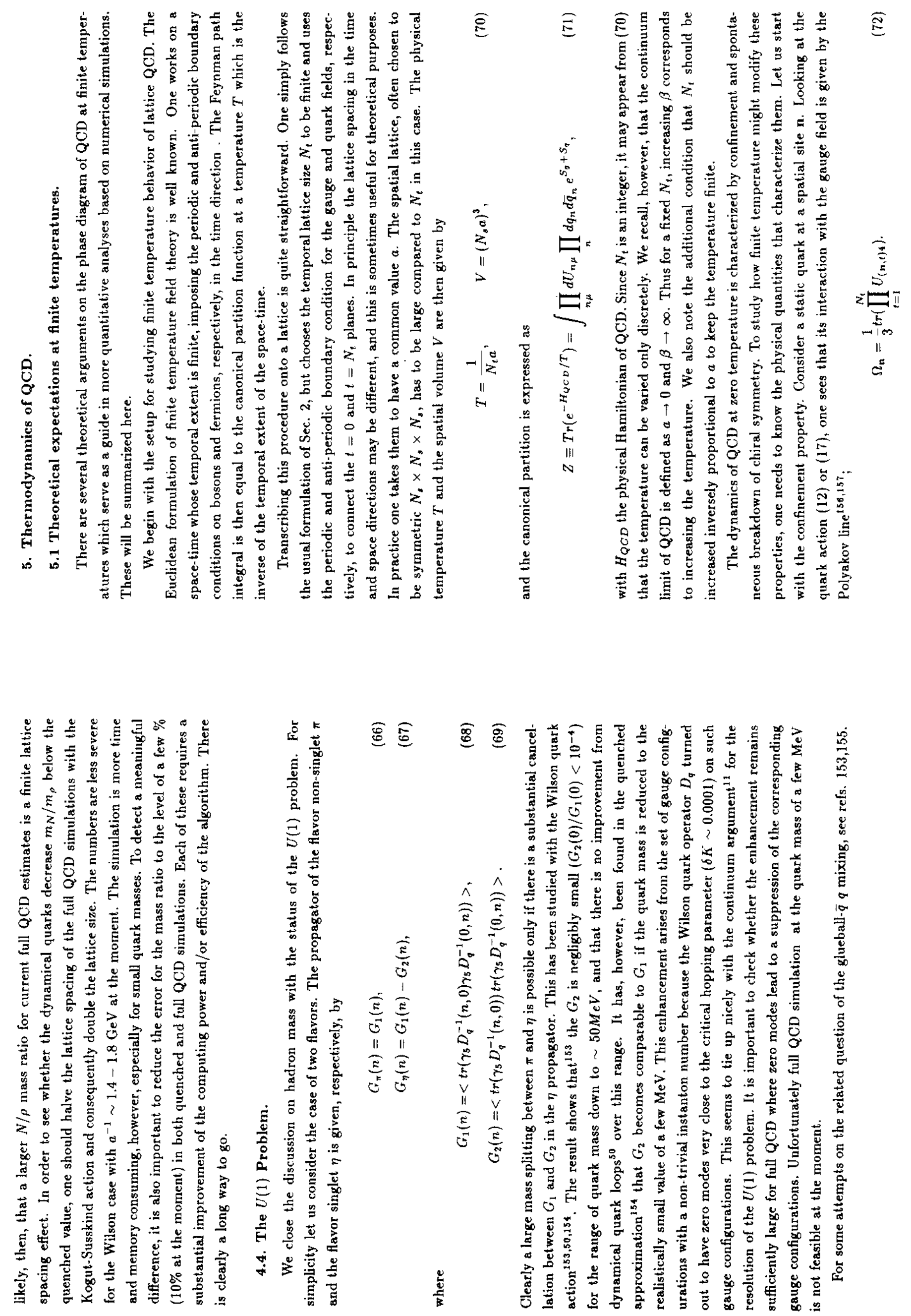


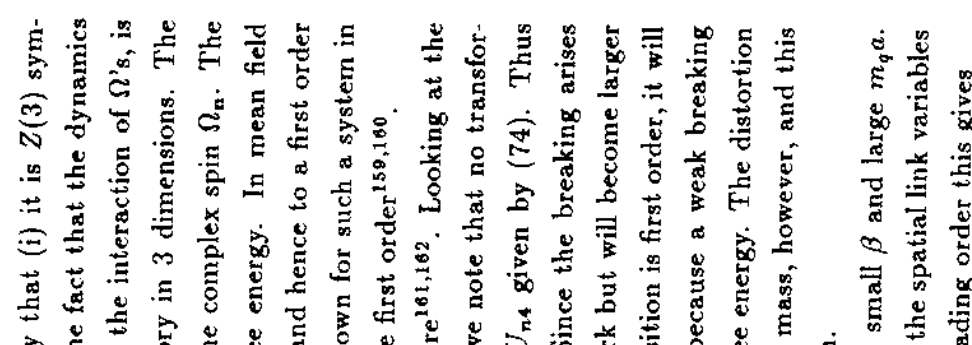

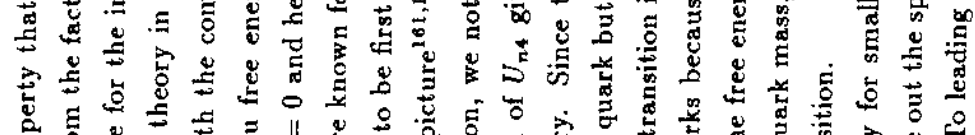

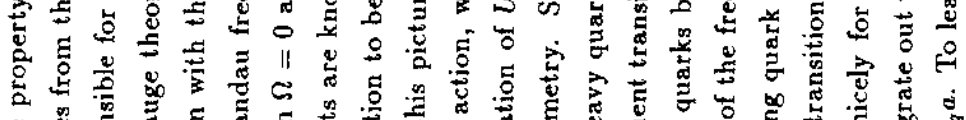

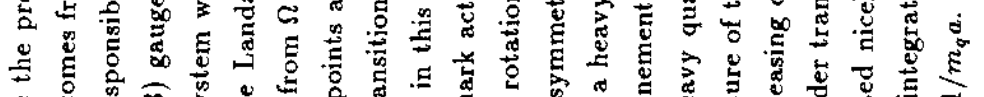

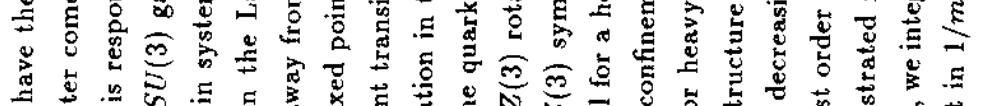

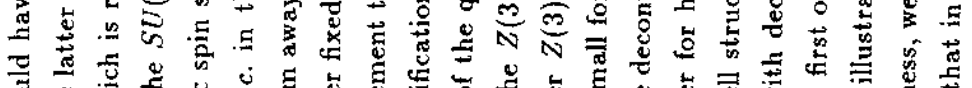

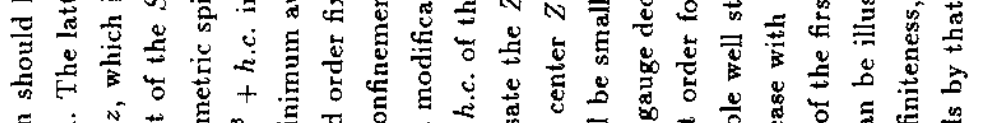

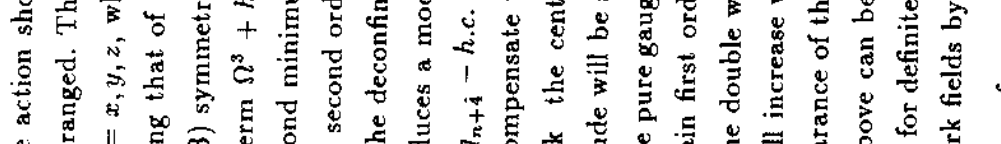

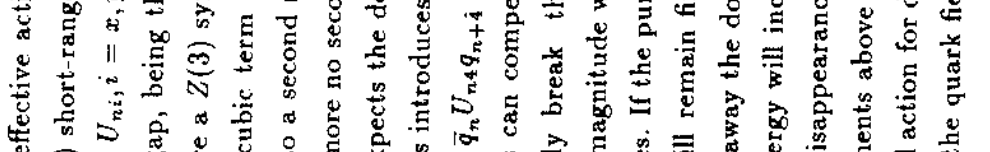

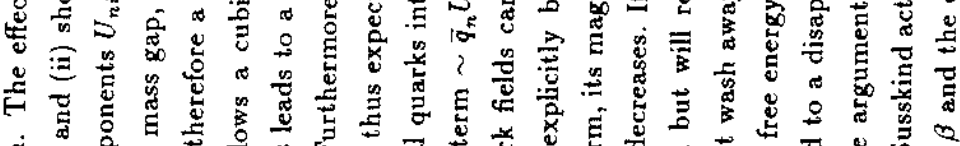

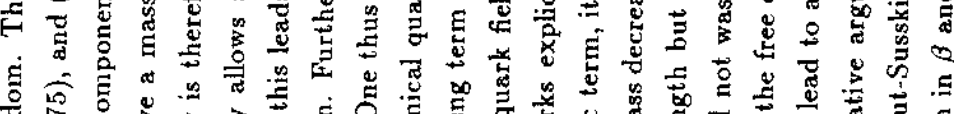

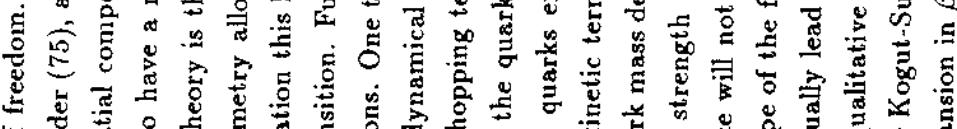

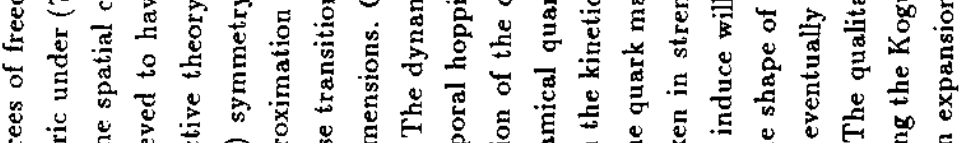

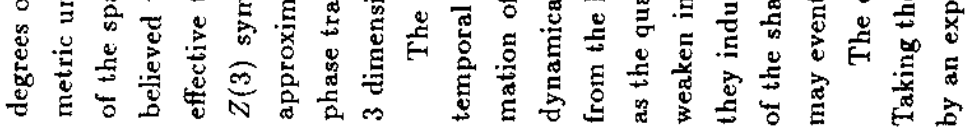
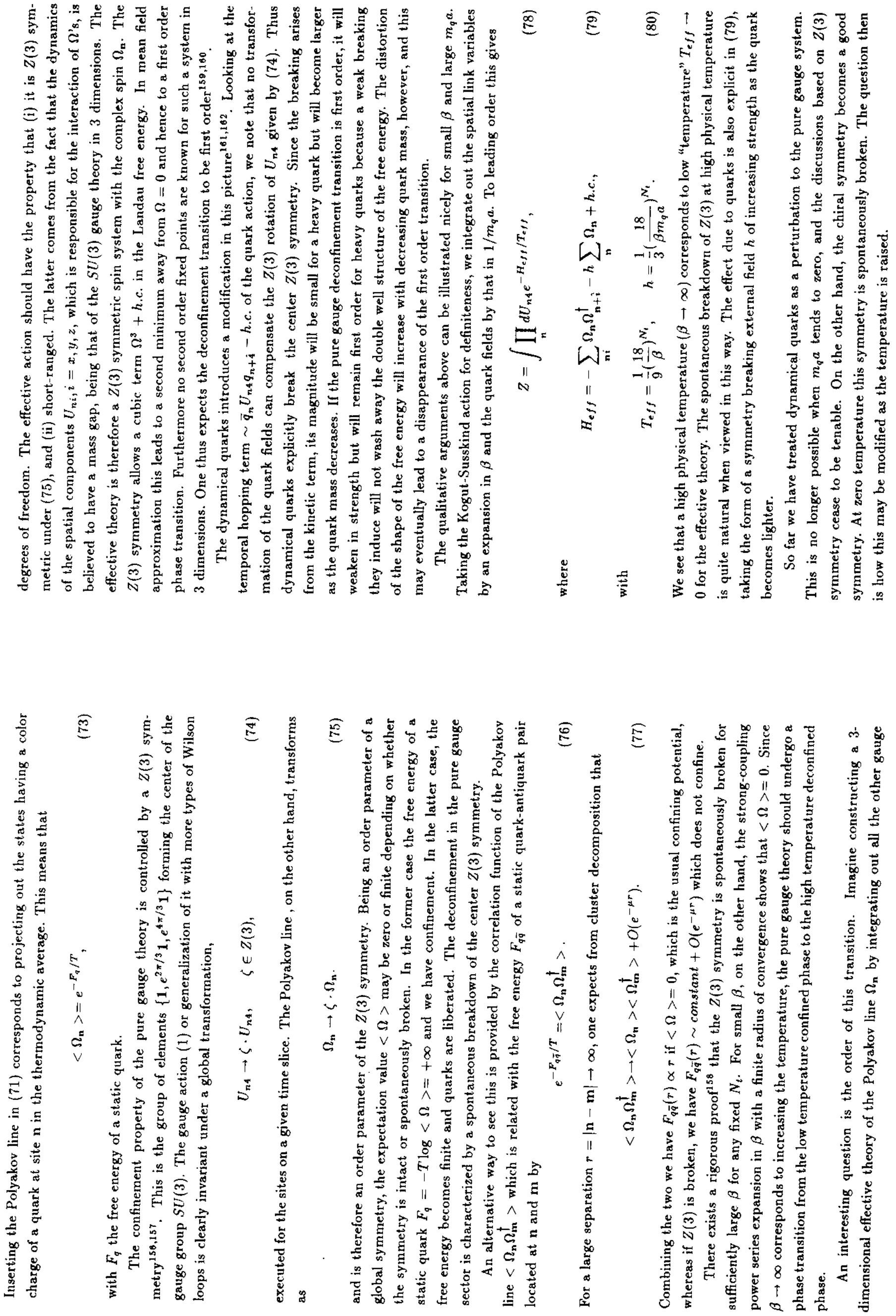


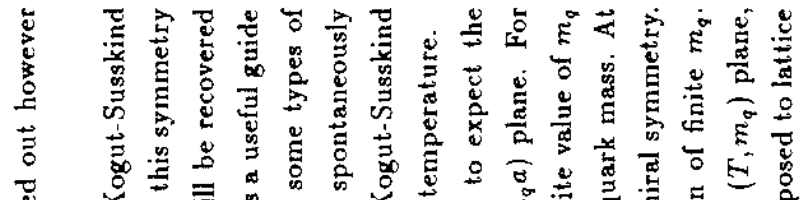
₹ E

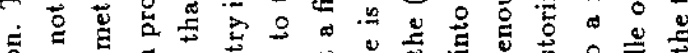

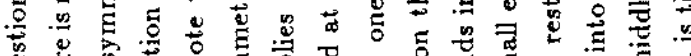

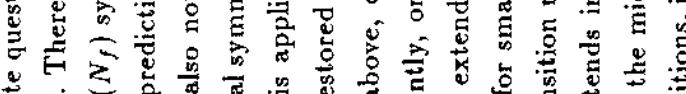

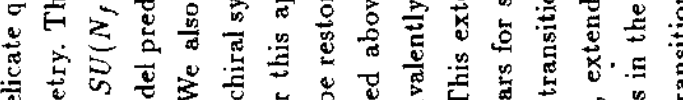

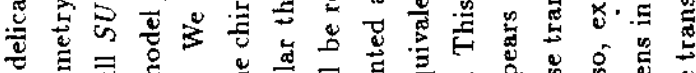

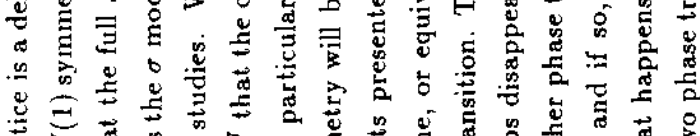

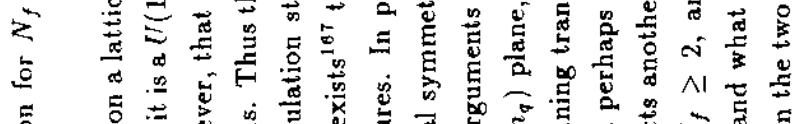

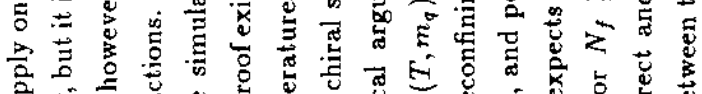

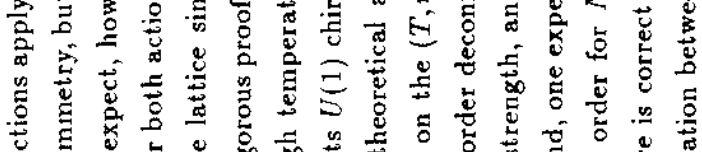

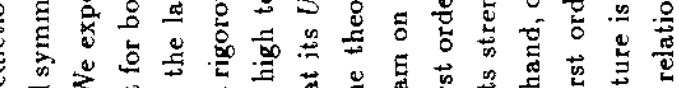

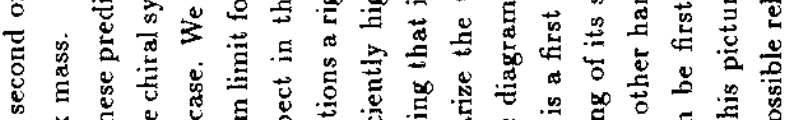
至

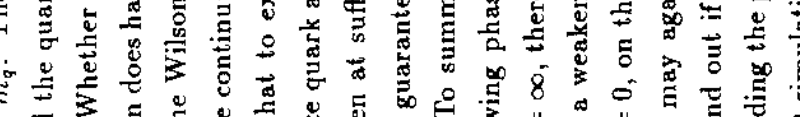
minn

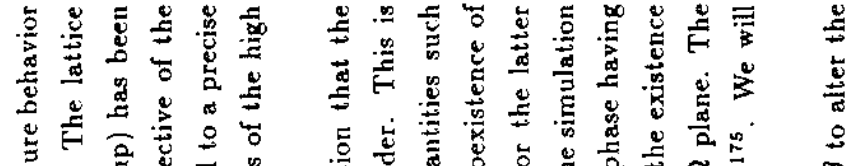

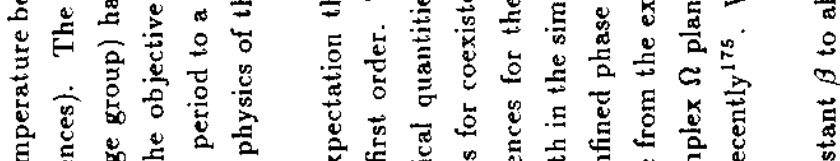

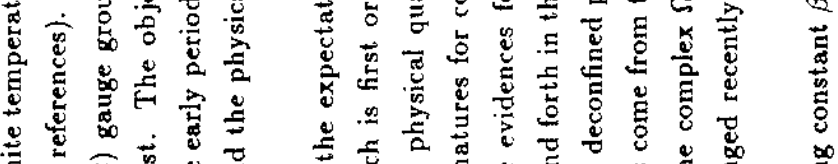

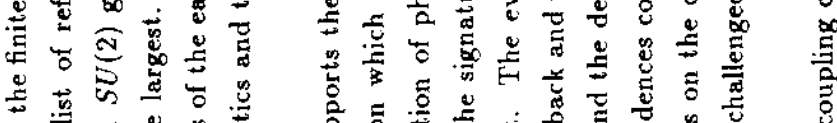

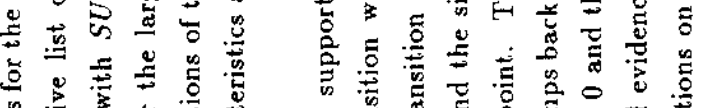

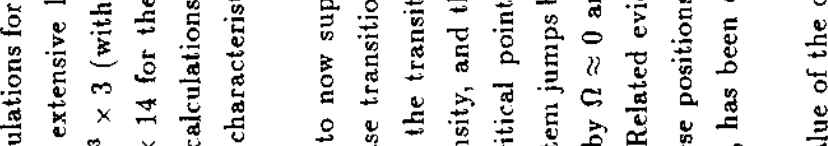

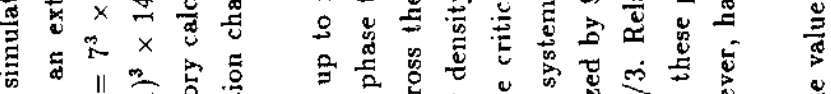

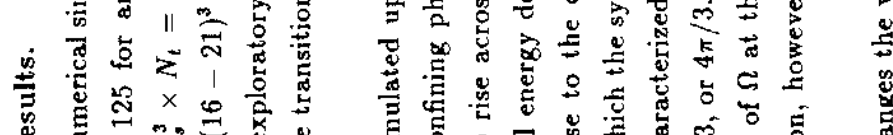

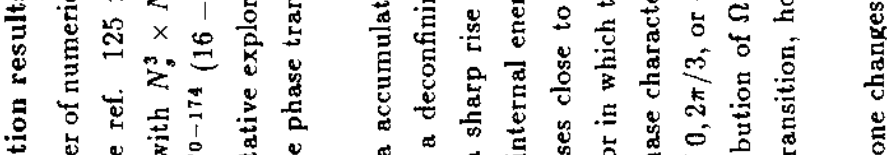

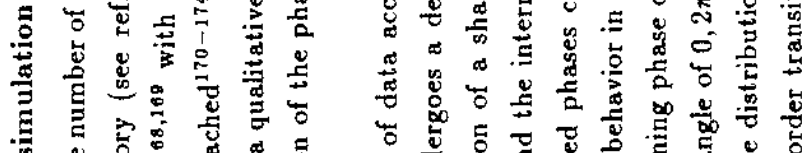

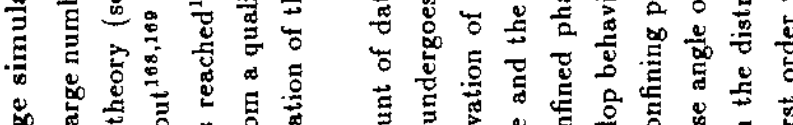

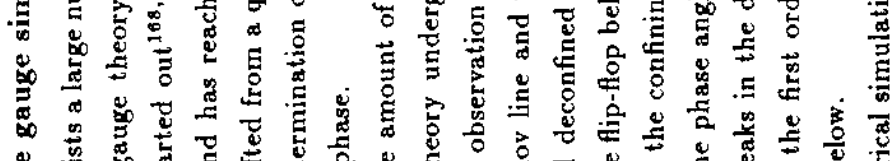

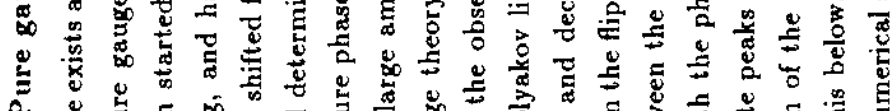

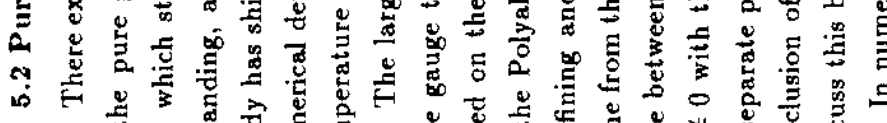

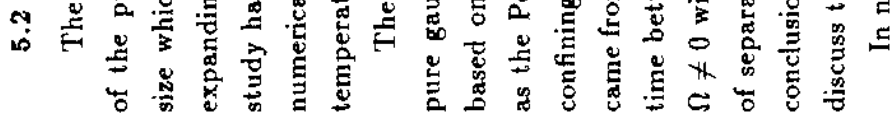

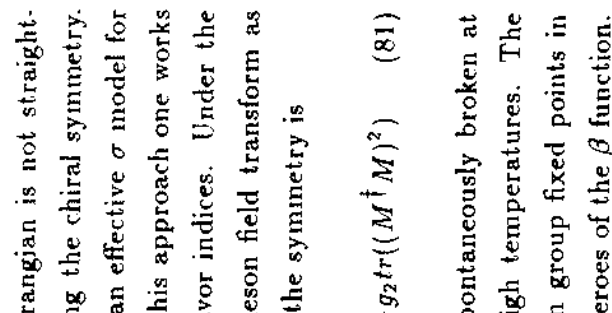

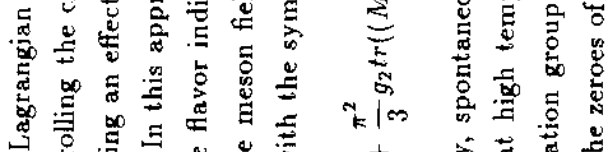

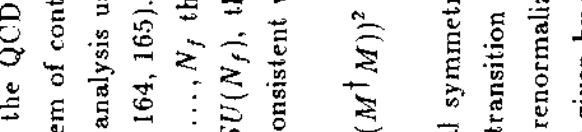

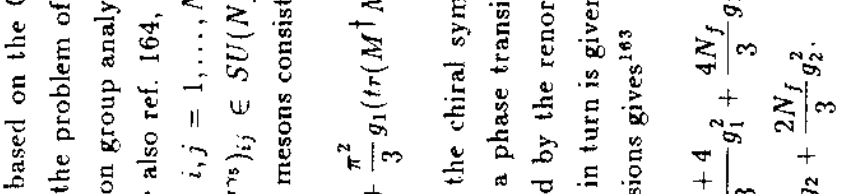

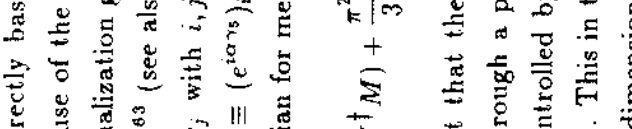

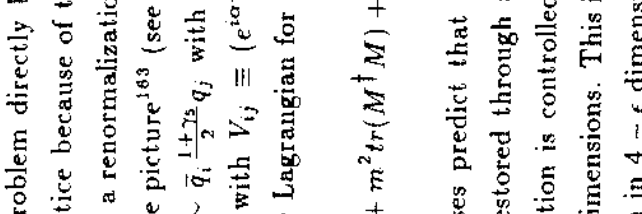

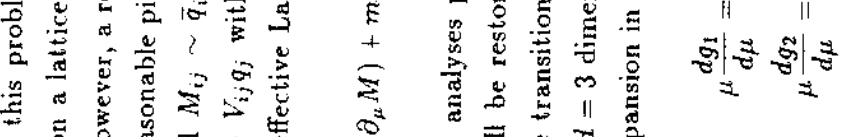

की

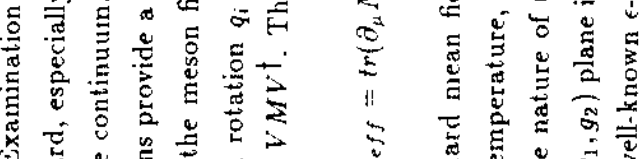

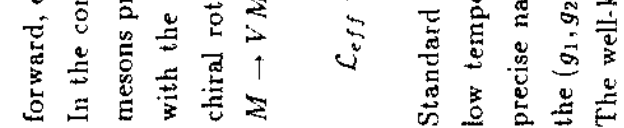

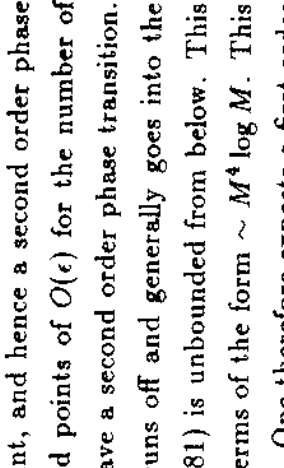

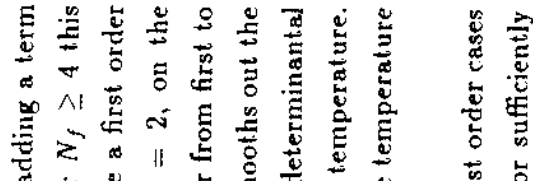

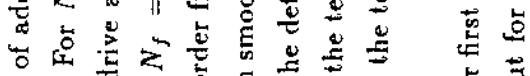

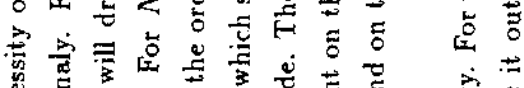

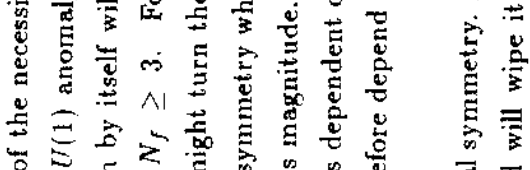

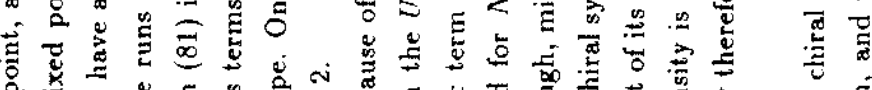

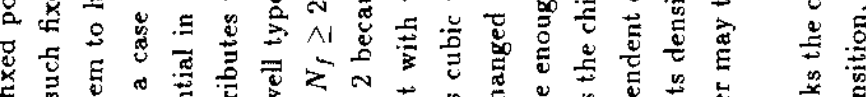

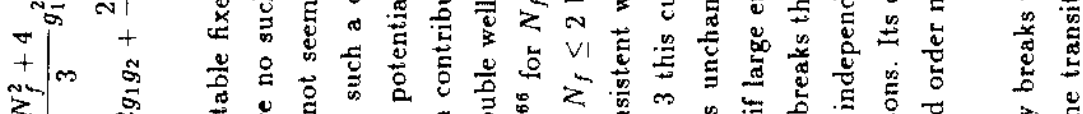

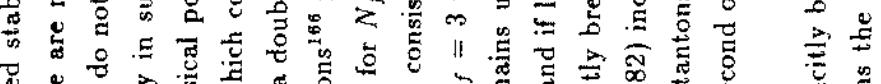

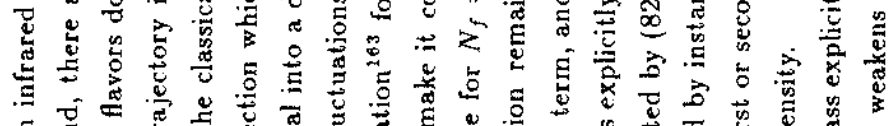

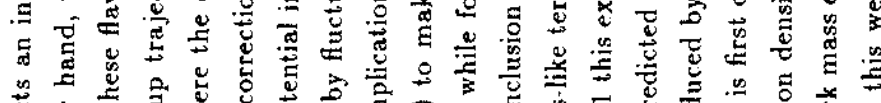

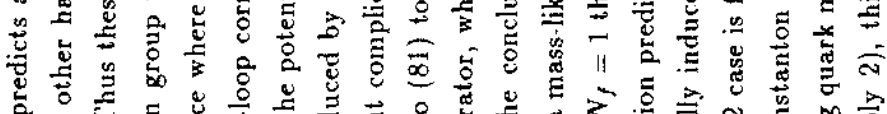

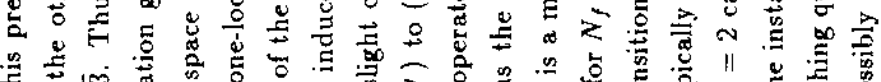

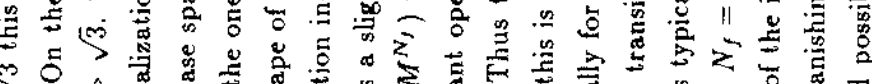

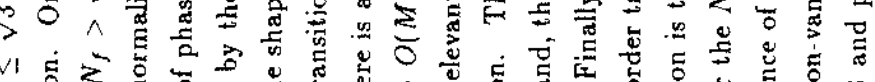

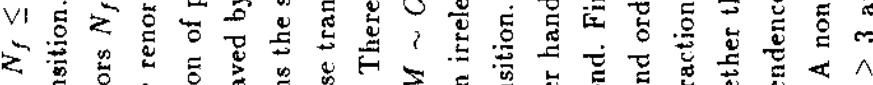

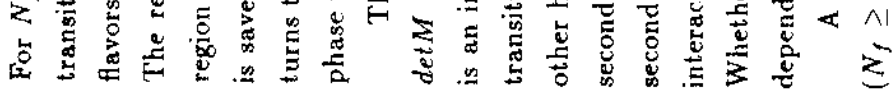




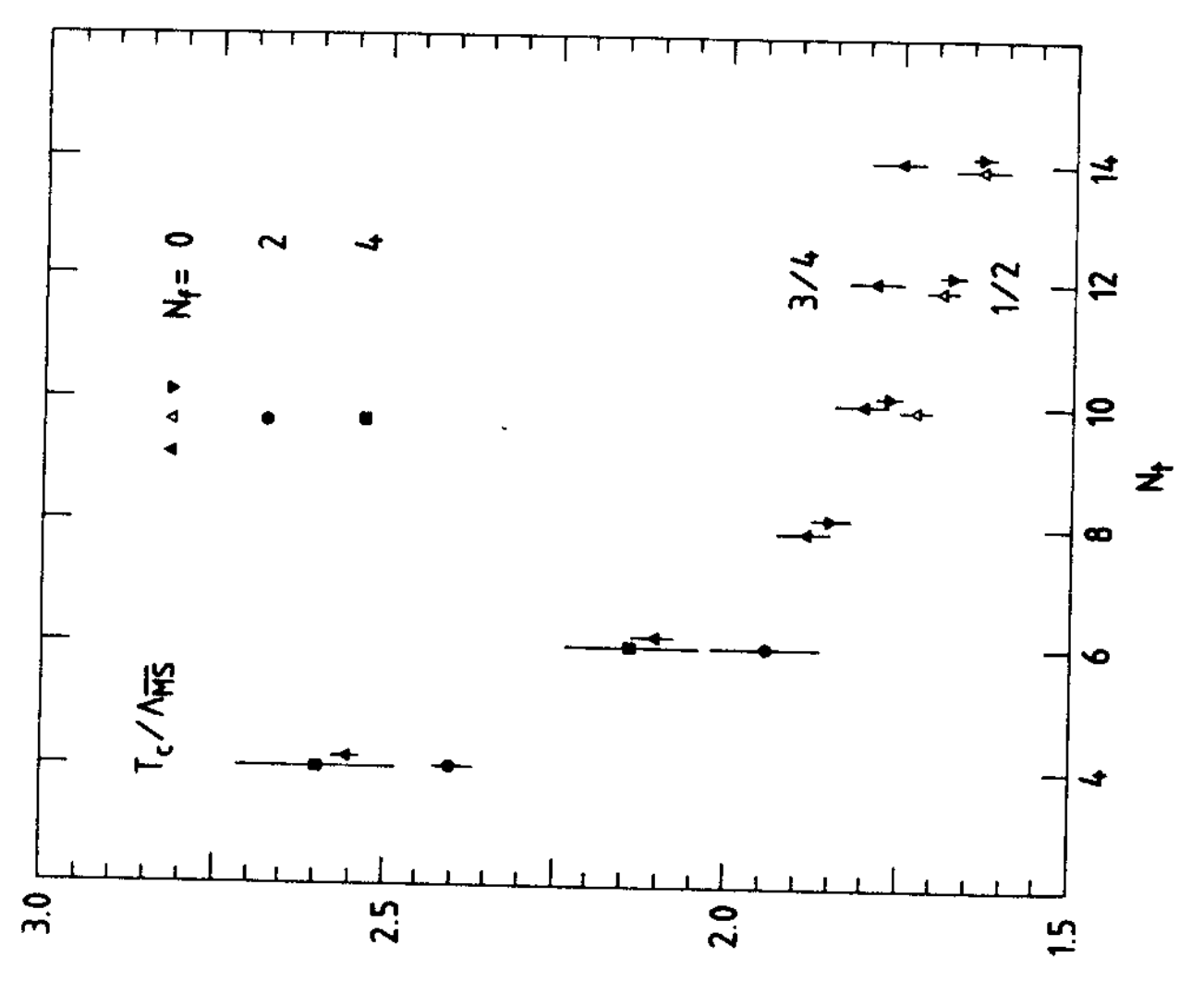

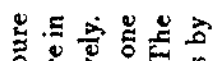

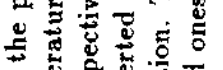

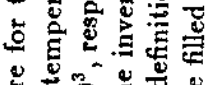

政

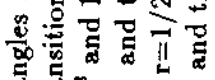

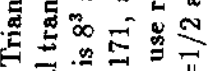

>

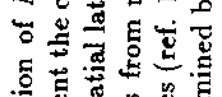

过若

20.

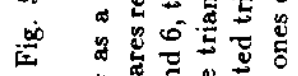

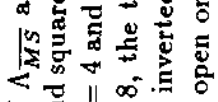

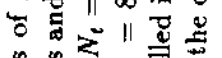

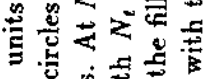

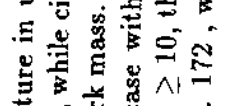

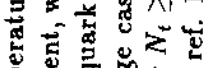

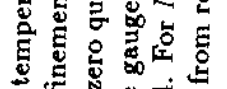

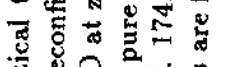

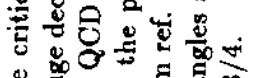

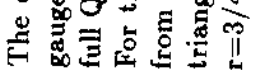

$\stackrel{0}{\infty}$

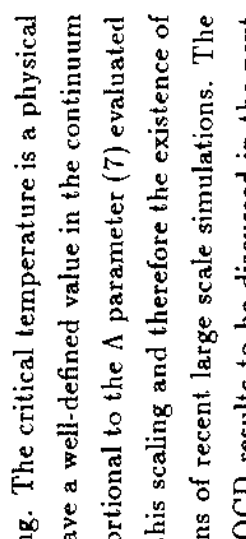

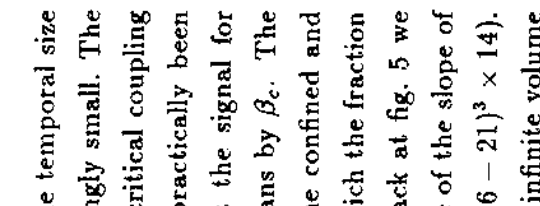

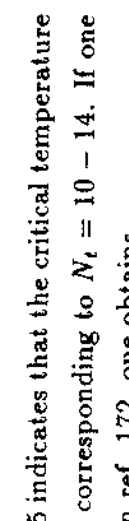

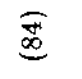

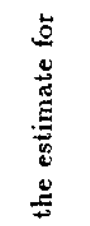

$\stackrel{\bar{x}}{\underline{0}}$

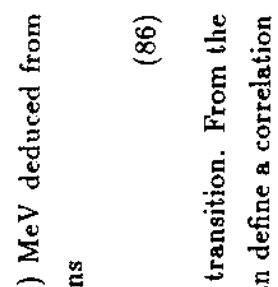

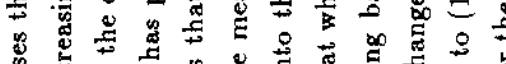

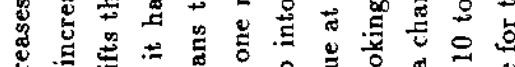

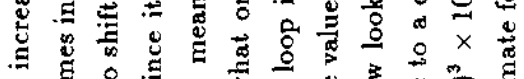

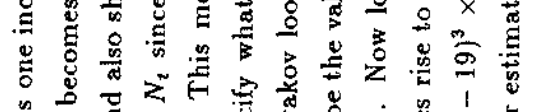

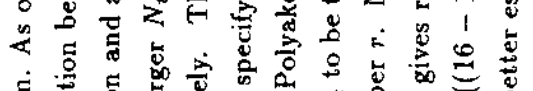

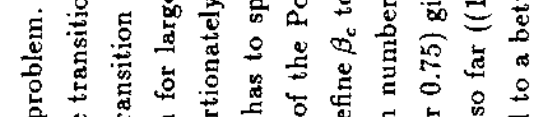

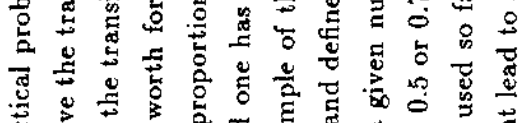

in

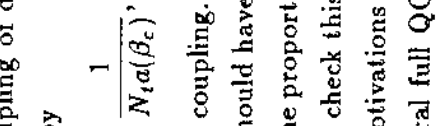

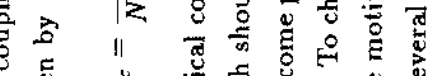

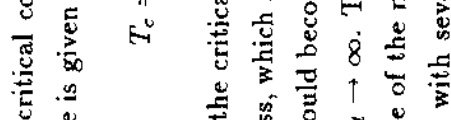

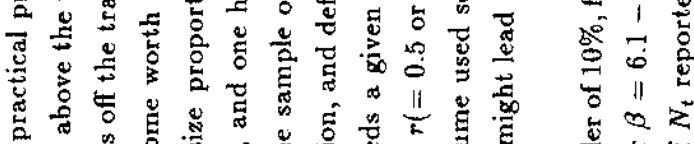

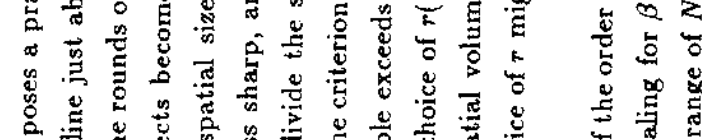

$\cong$

蓶

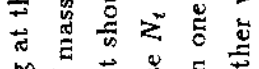

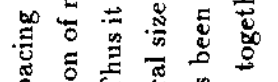

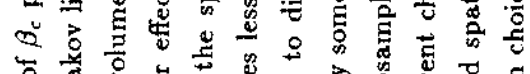

要起

然

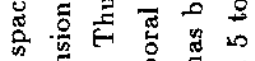

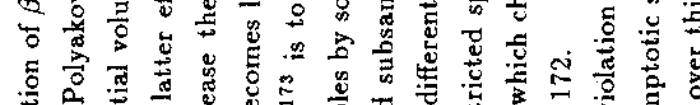

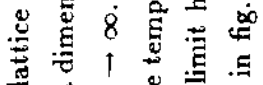

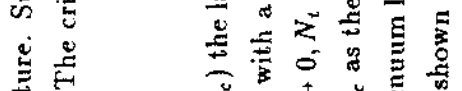

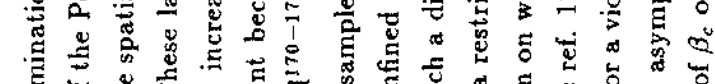

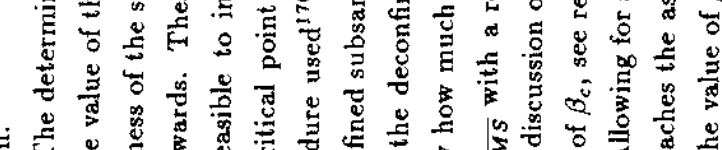

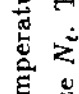

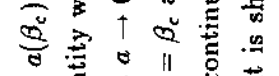

竎

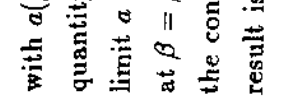

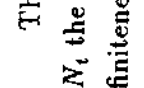

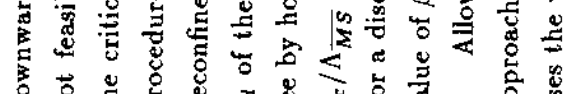

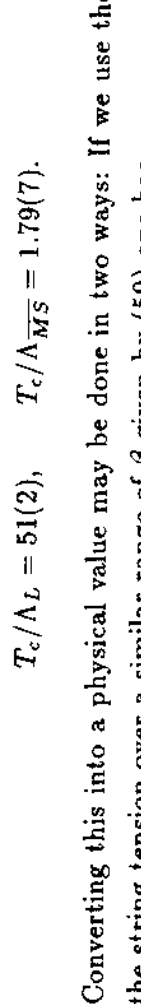

$\| \stackrel{0}{2}$

政

․

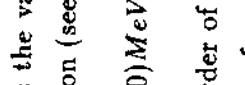

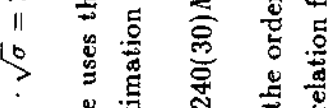

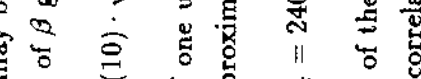

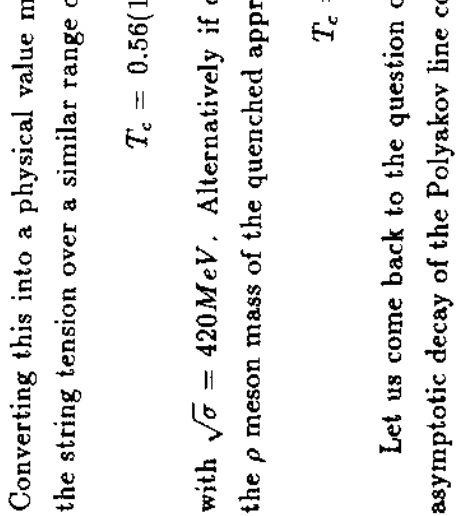




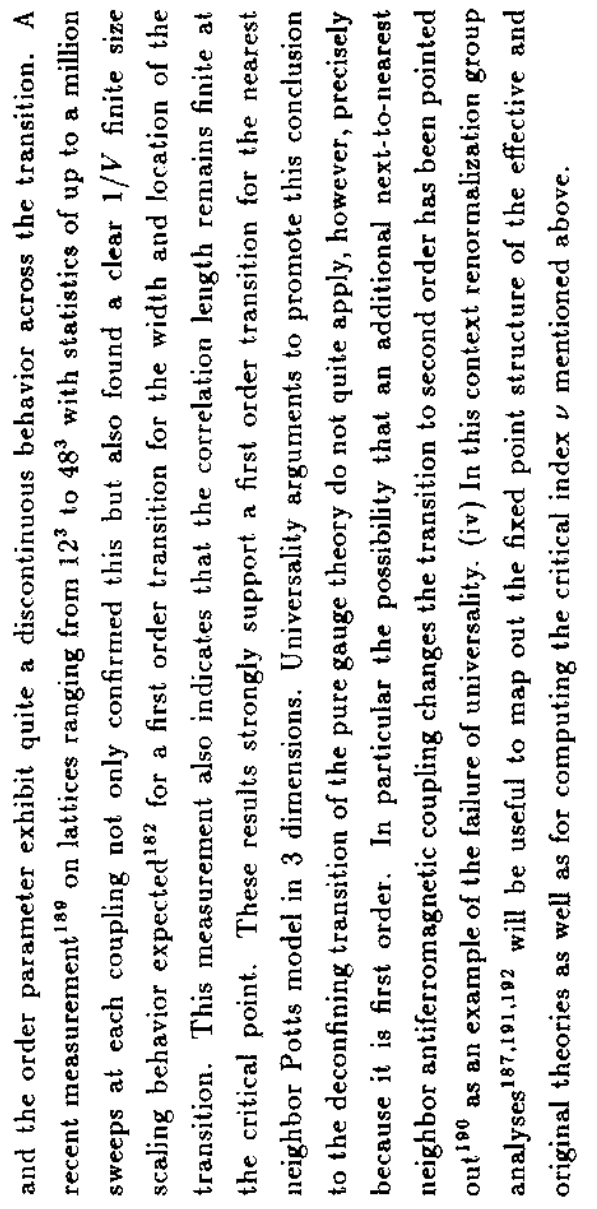

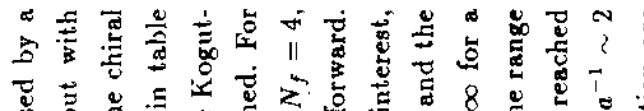

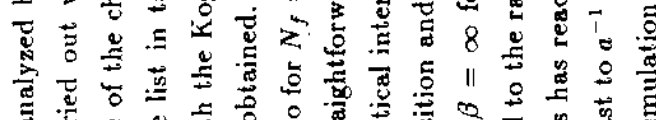

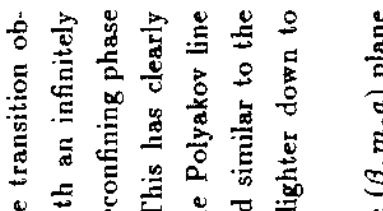

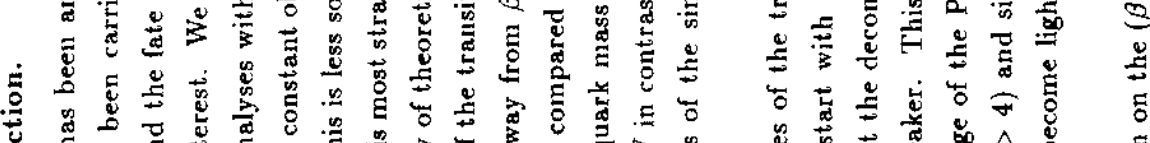

क

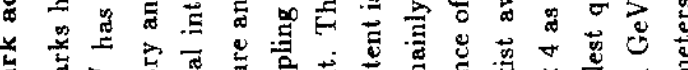

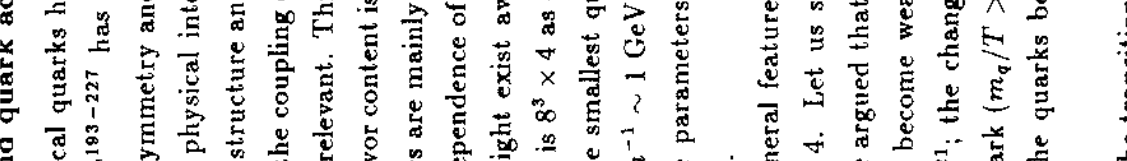

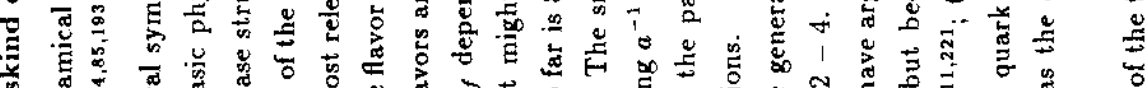

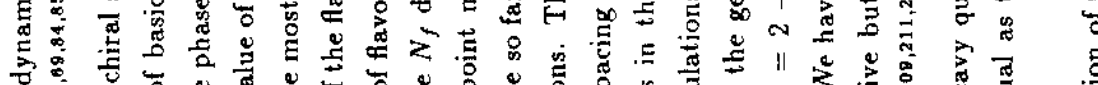

के

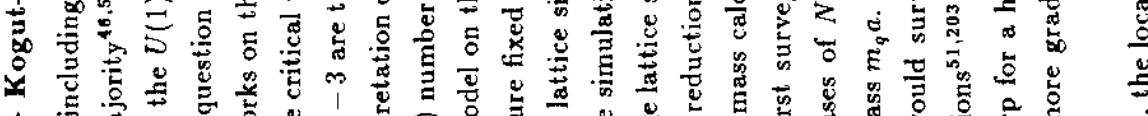

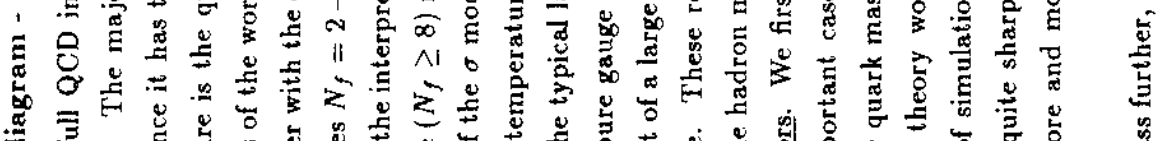

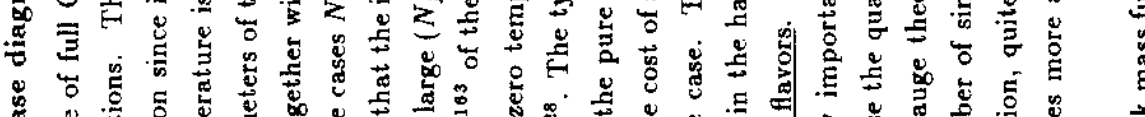

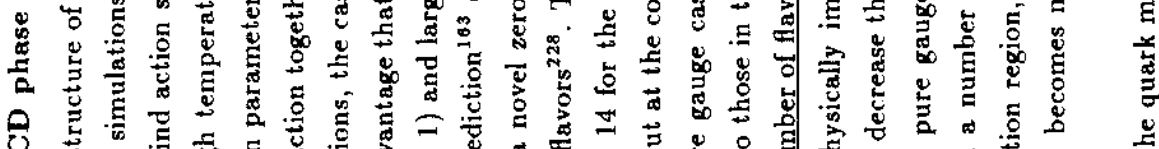

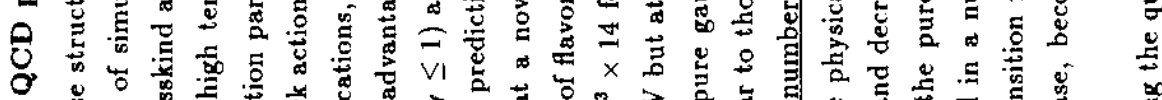

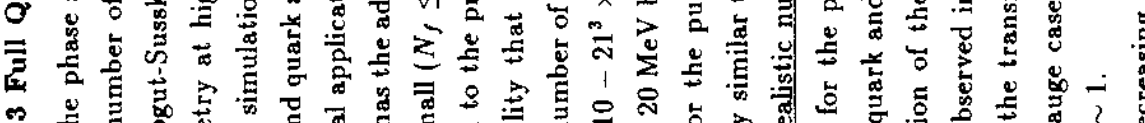

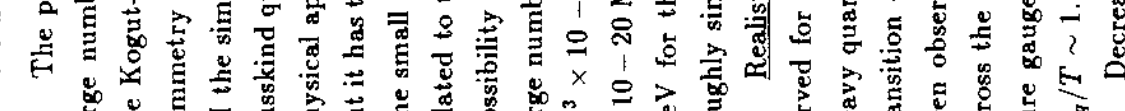

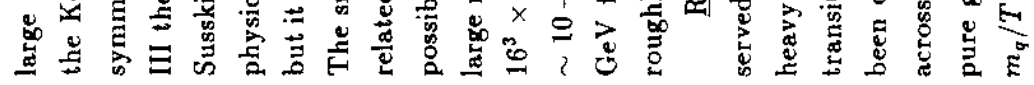

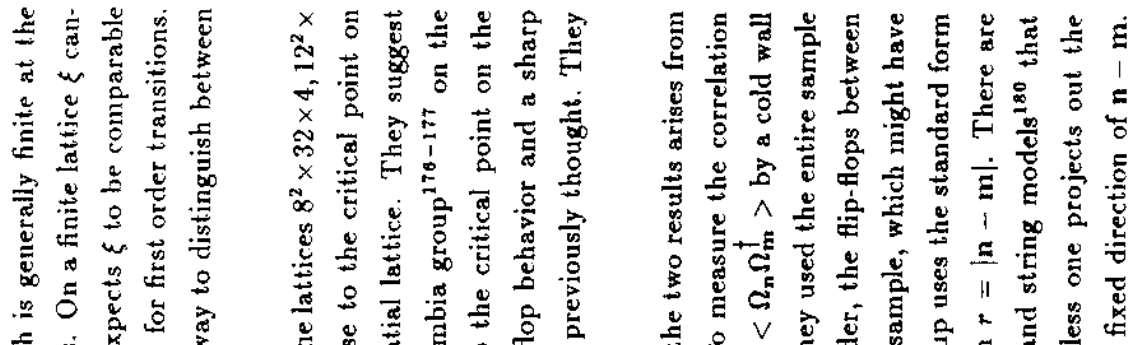

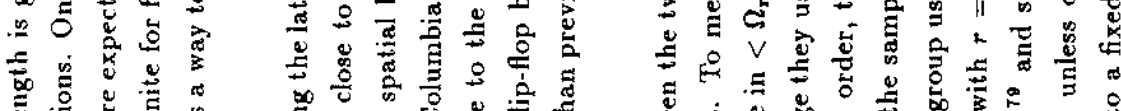

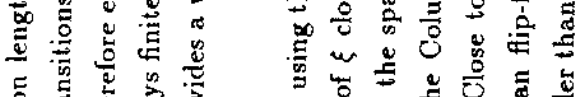

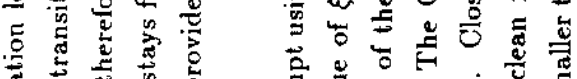

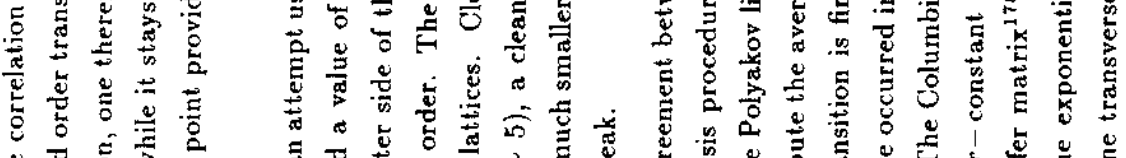

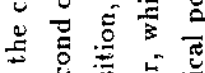

5

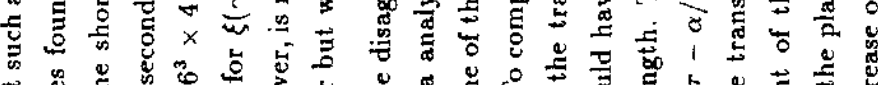

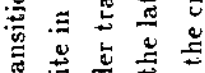

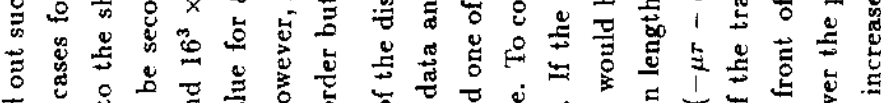

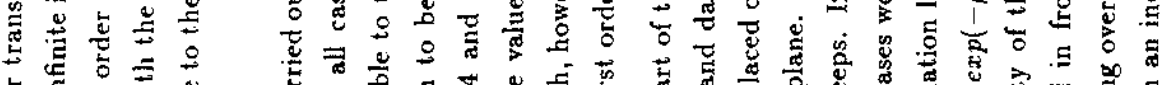

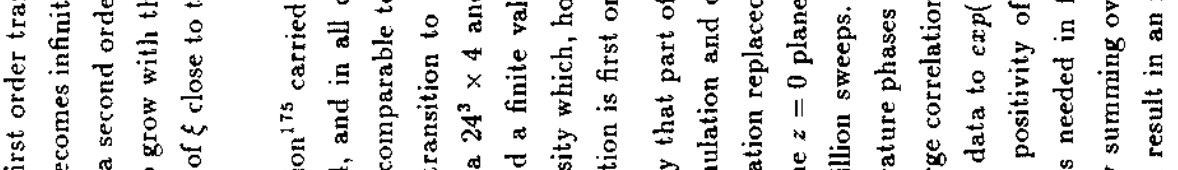

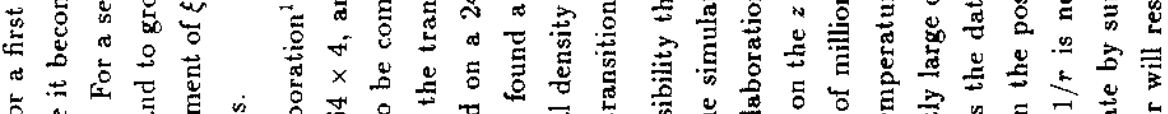

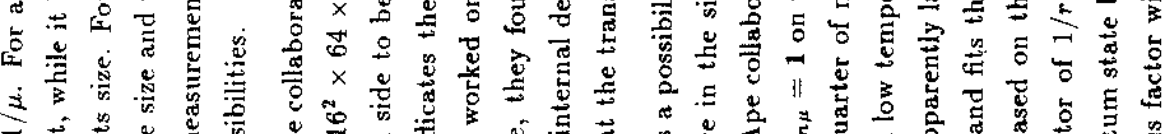

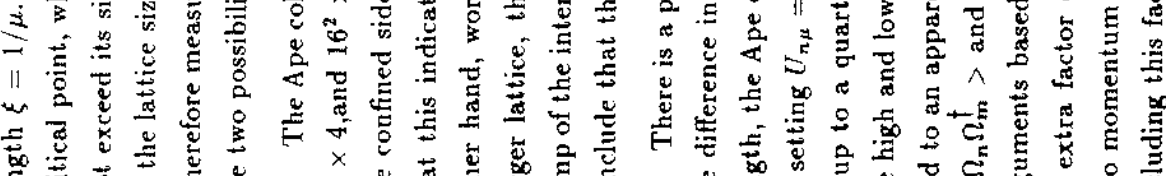

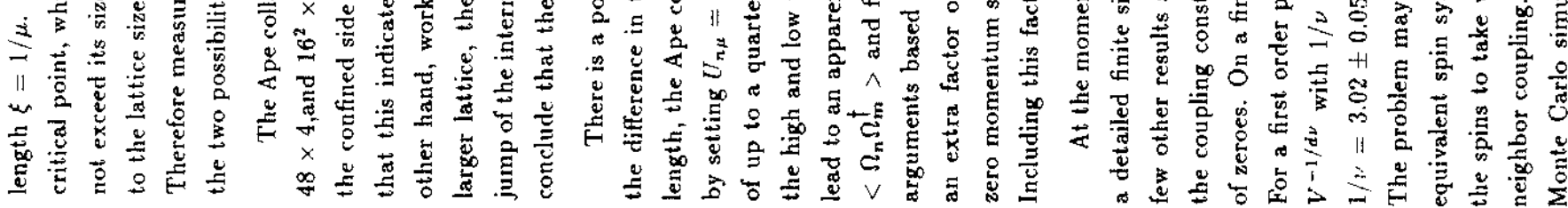

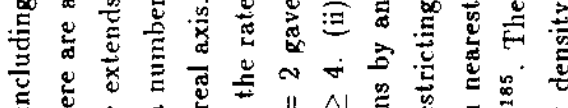

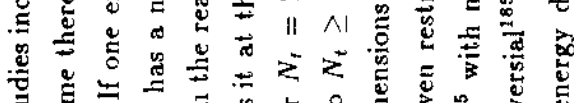

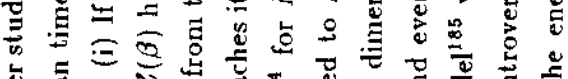

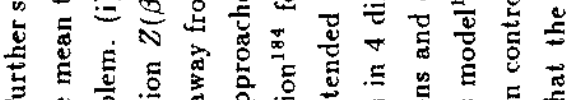

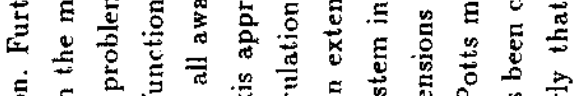

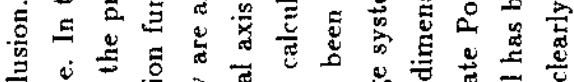

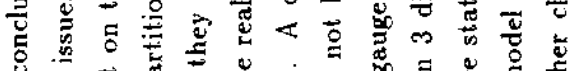

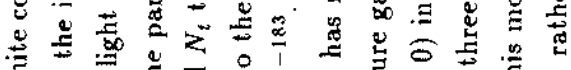

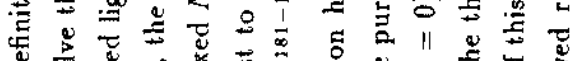

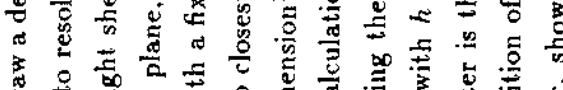

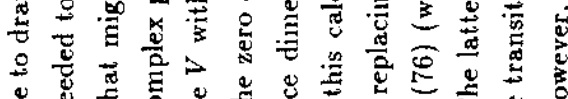

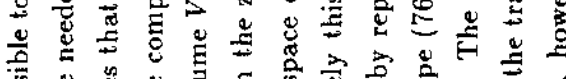

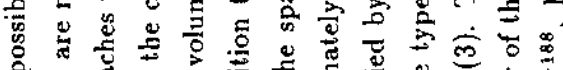

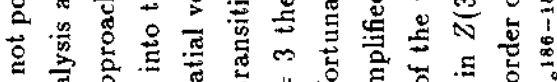

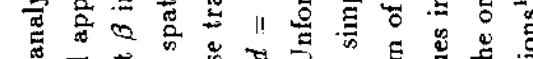

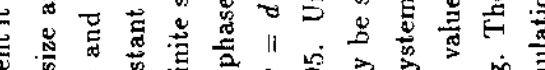

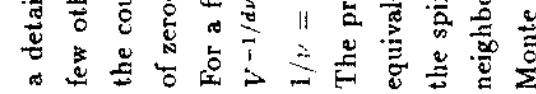




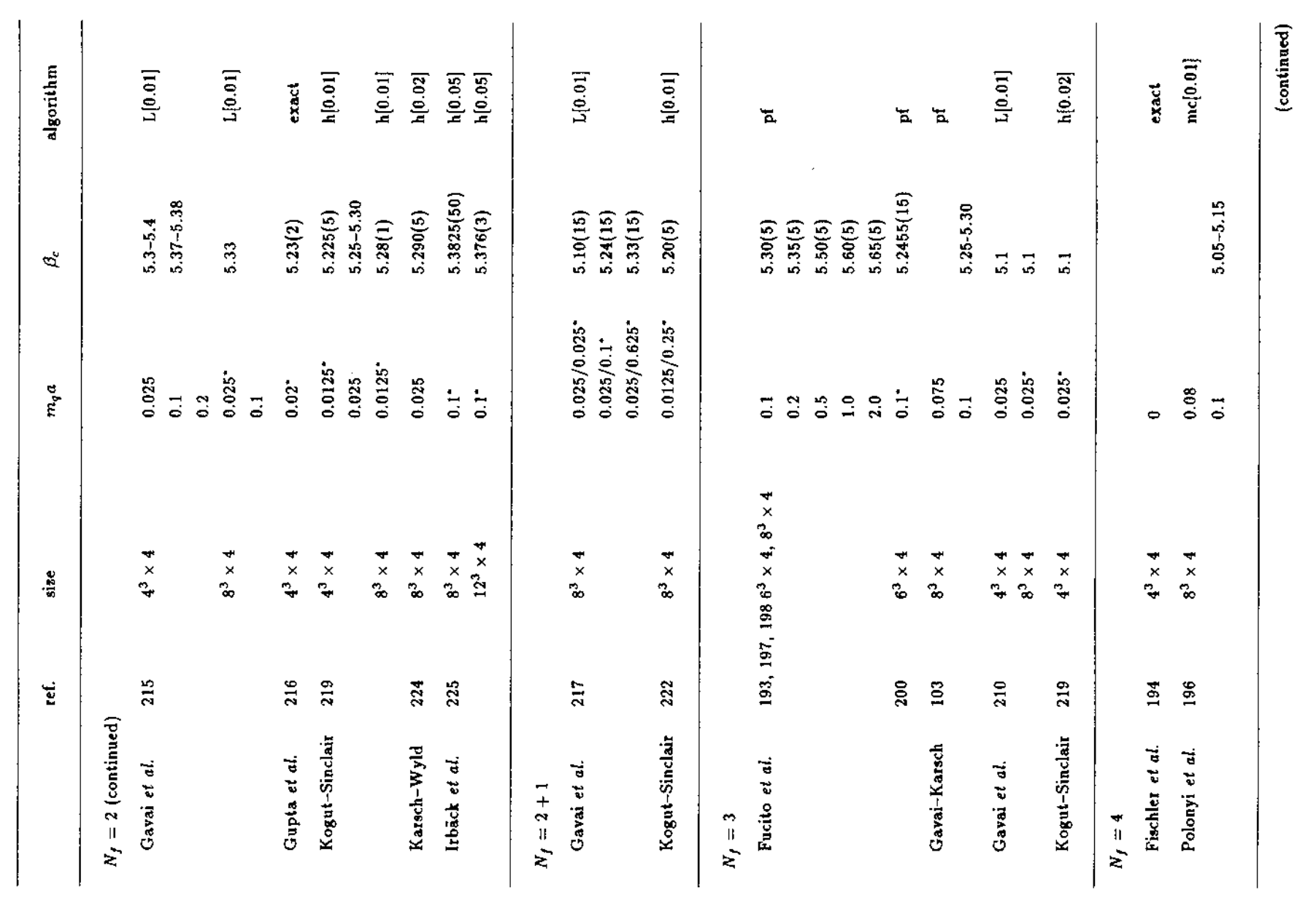

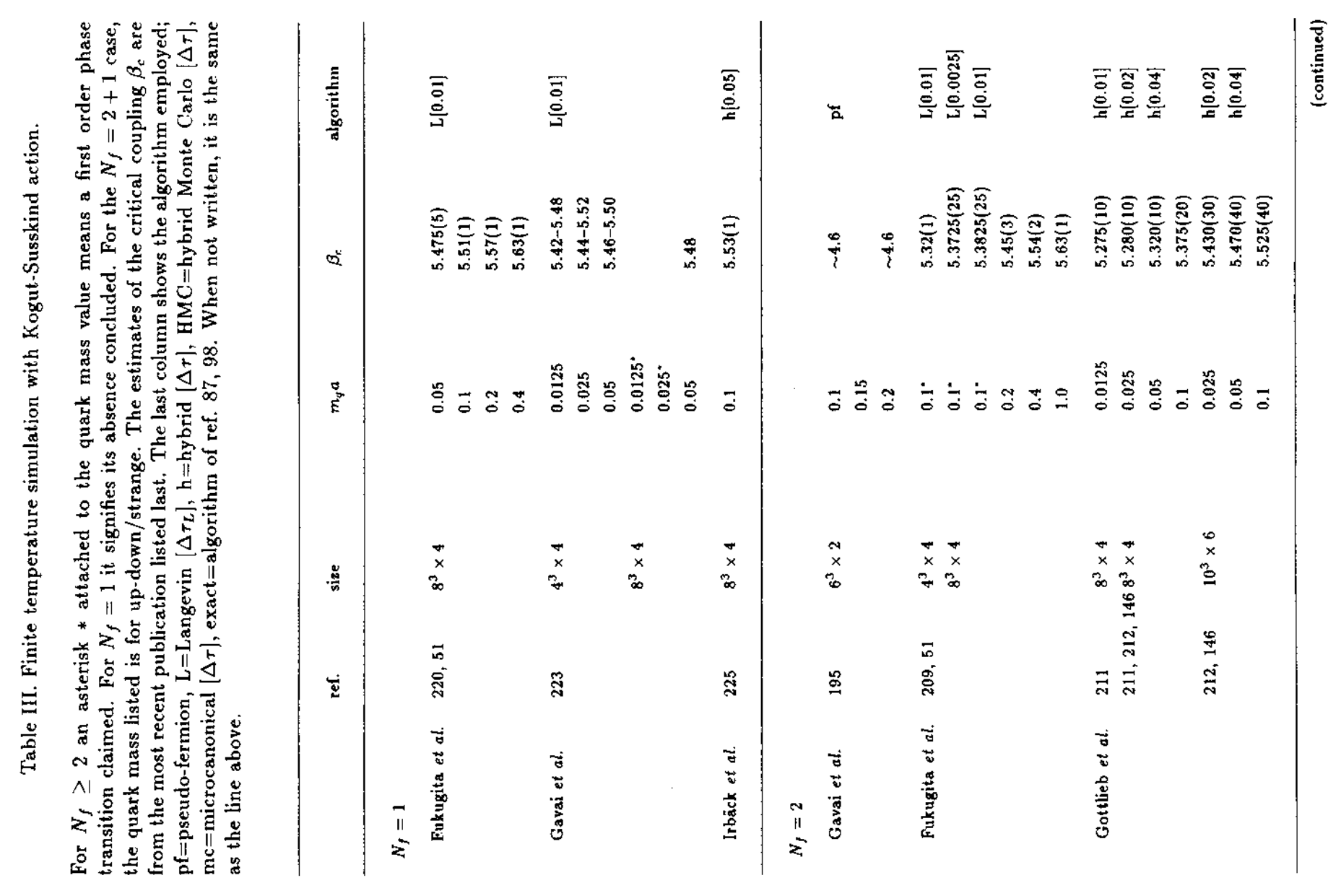




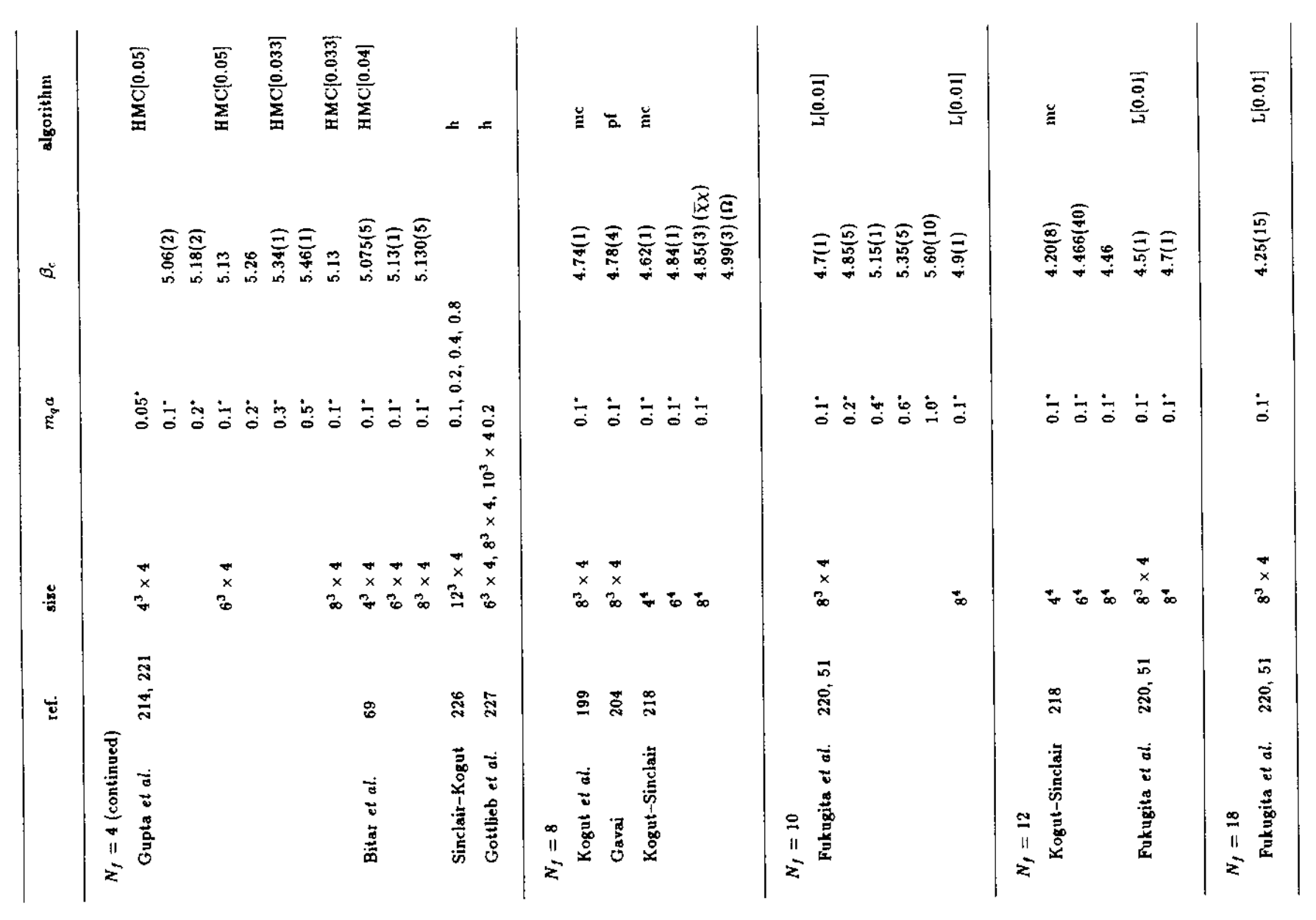




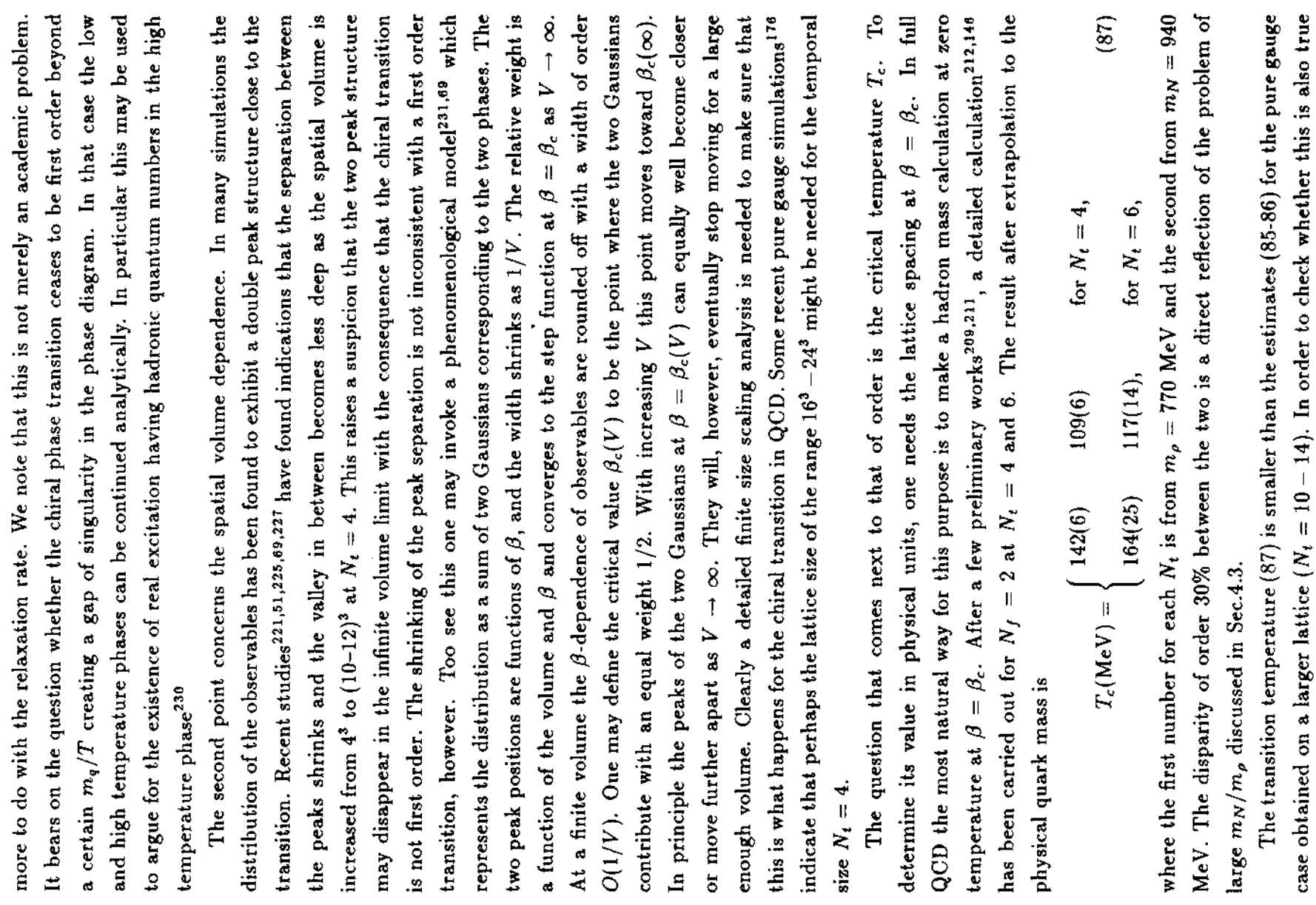

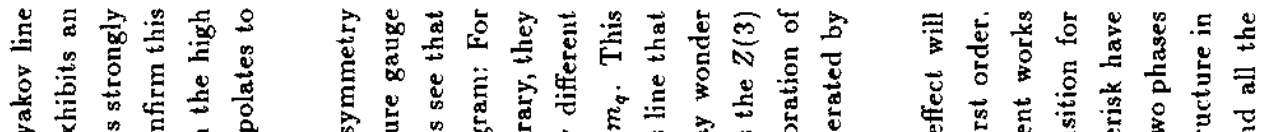
的 and In

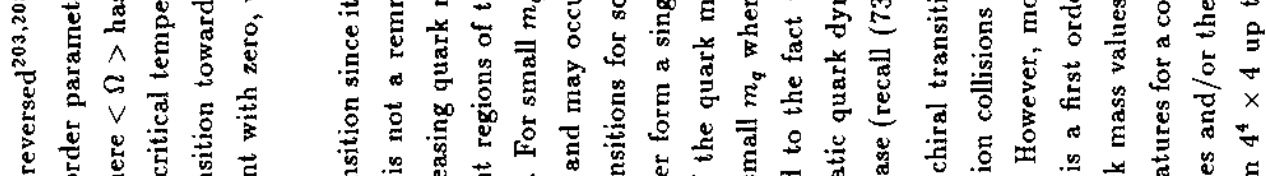
Wn minn MIn " f

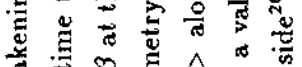
In my

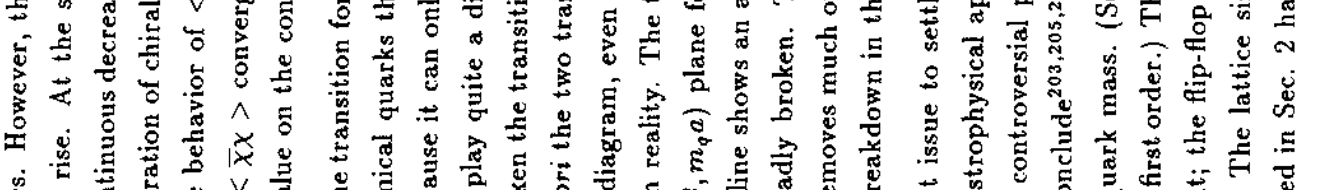
1 In

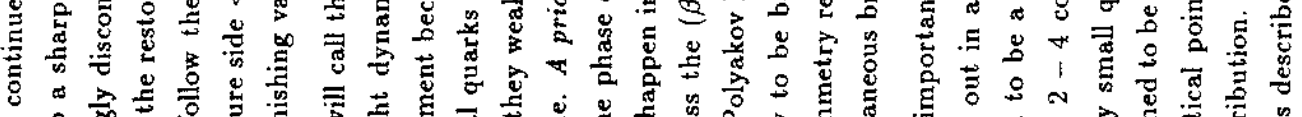

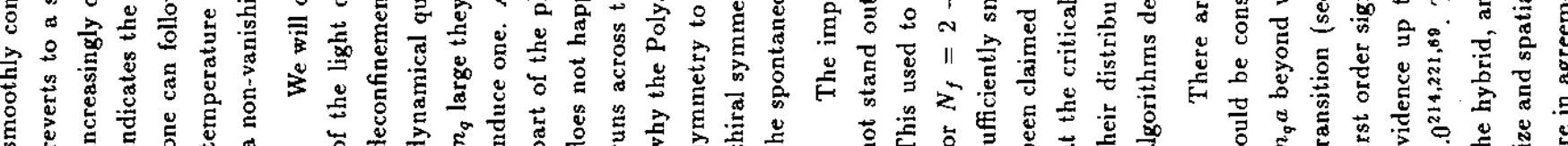

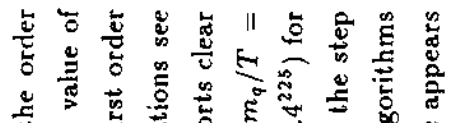

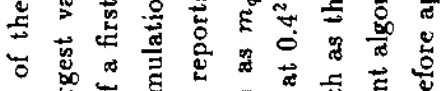

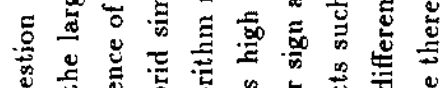

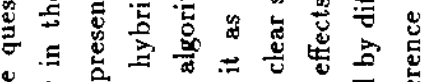

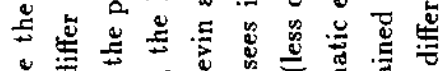

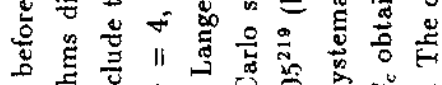

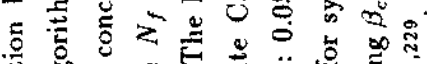

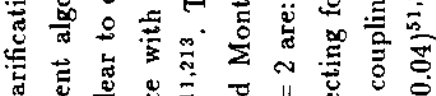

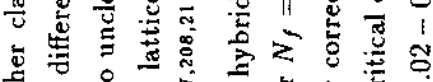

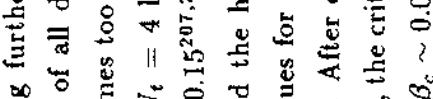

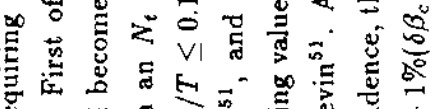

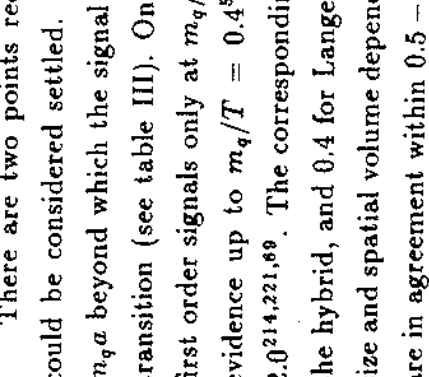




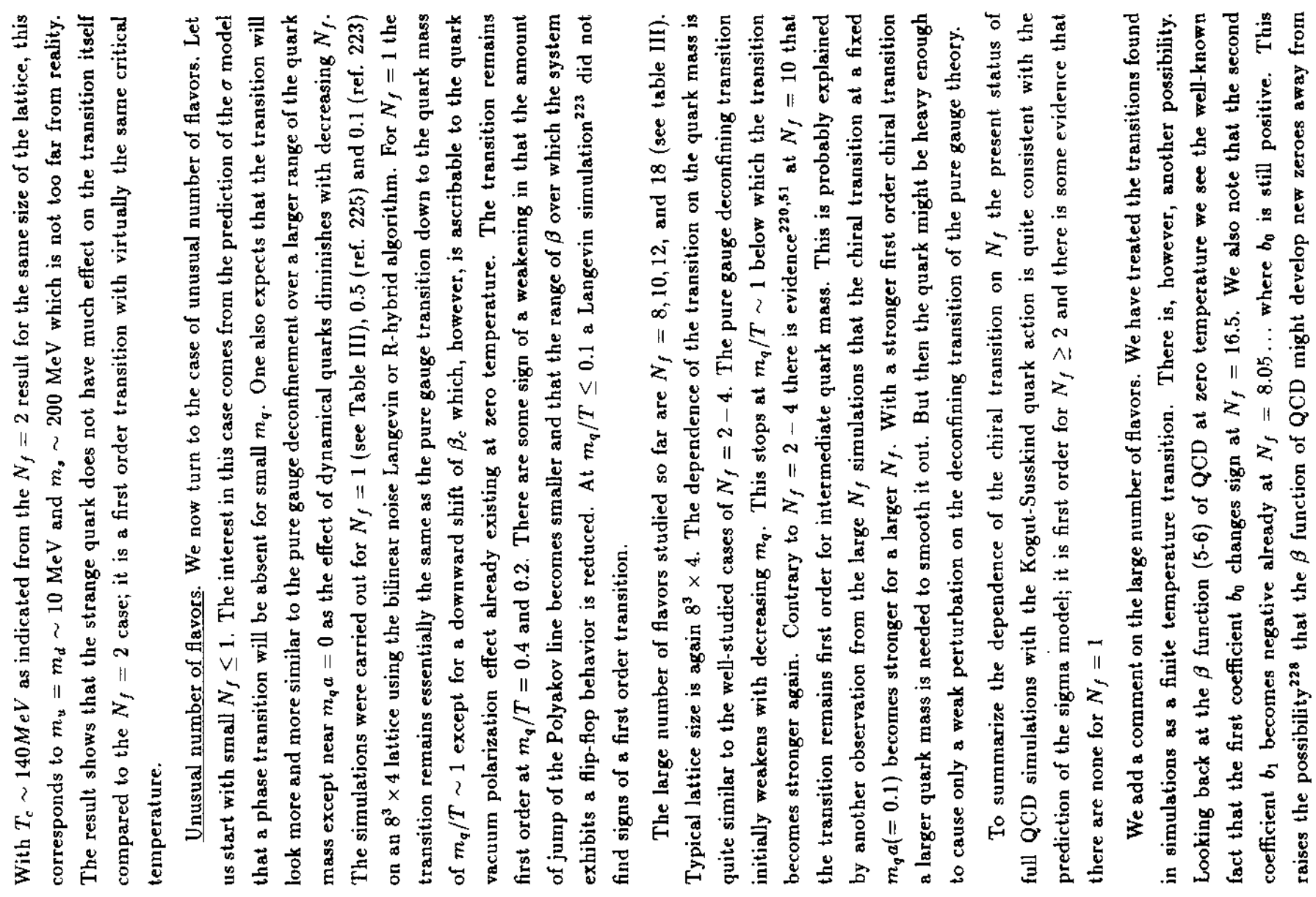

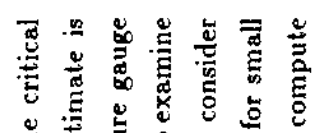

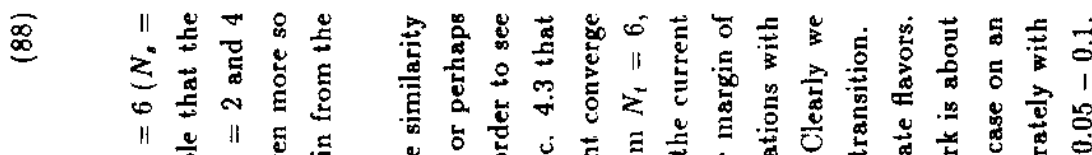

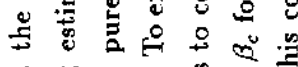

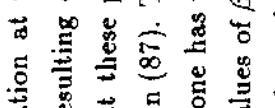

1)

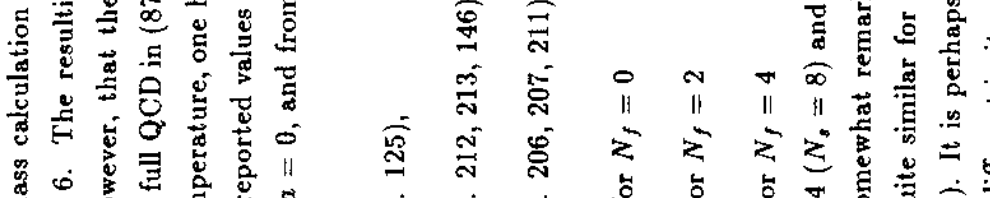

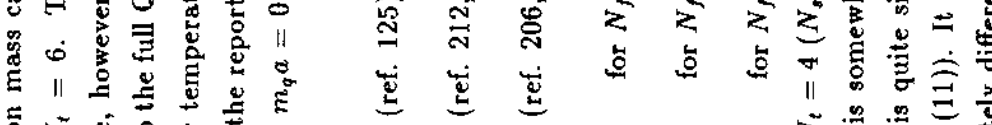

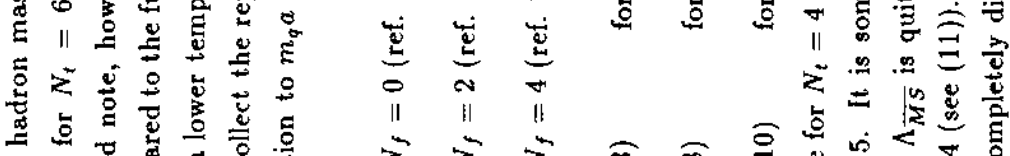

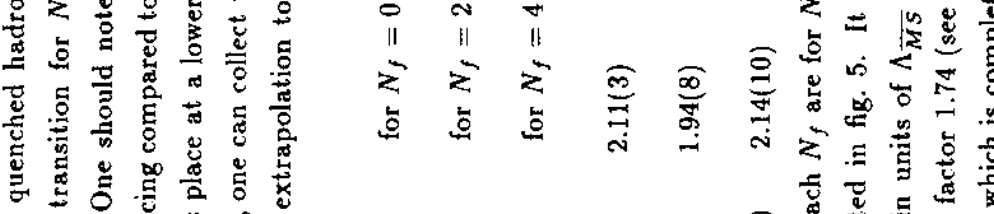

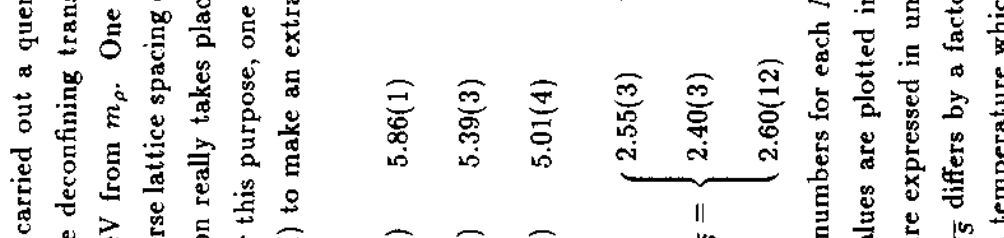

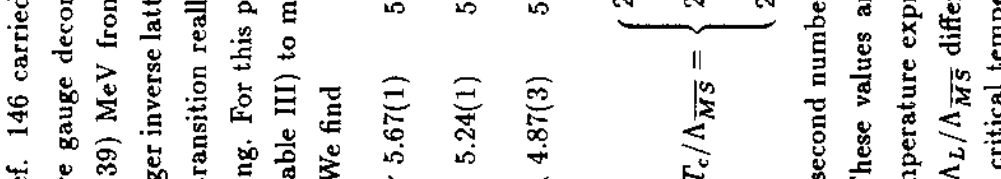

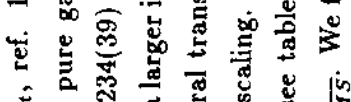

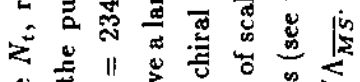

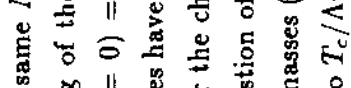

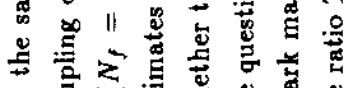
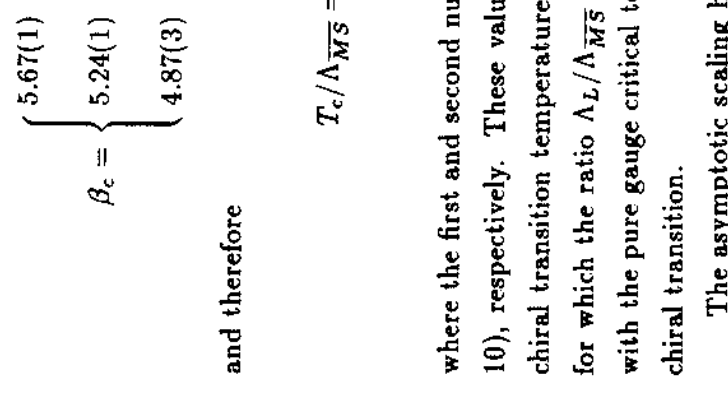

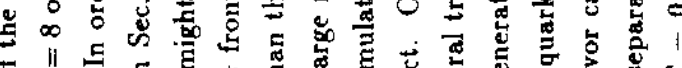

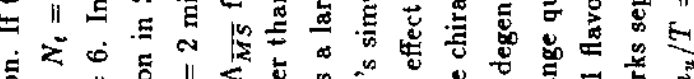

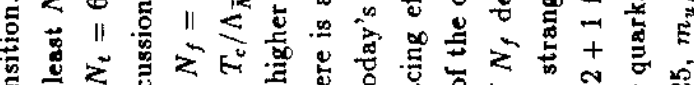

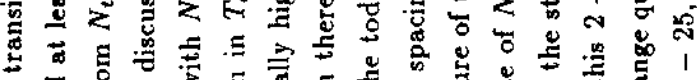

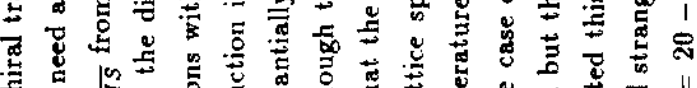

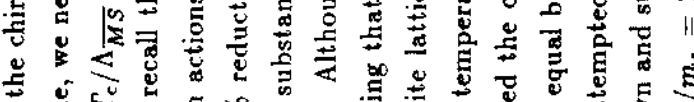

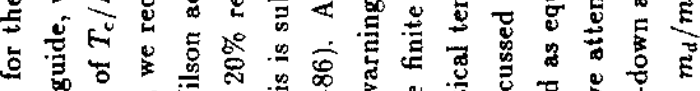
I ปे

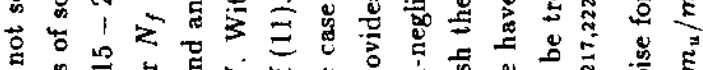

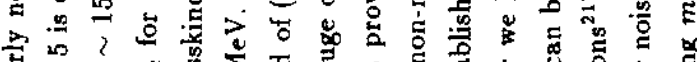

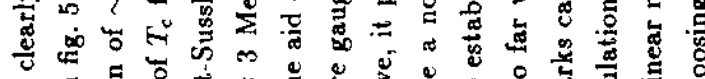

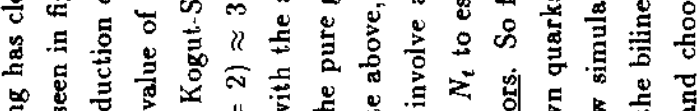

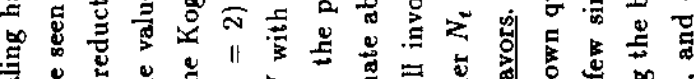

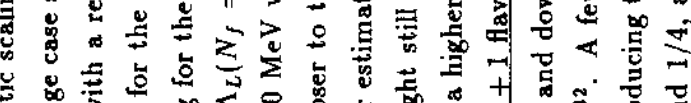

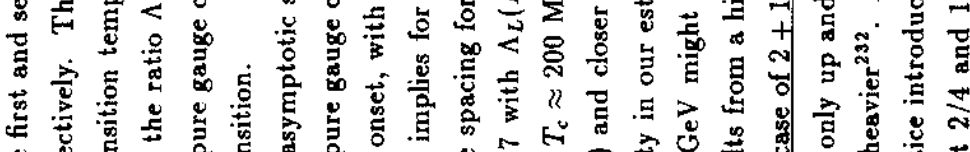

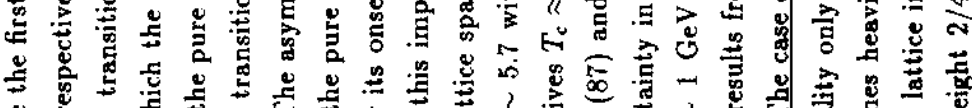

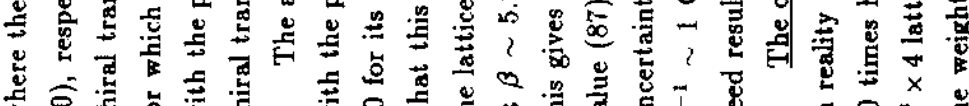

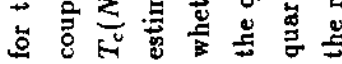




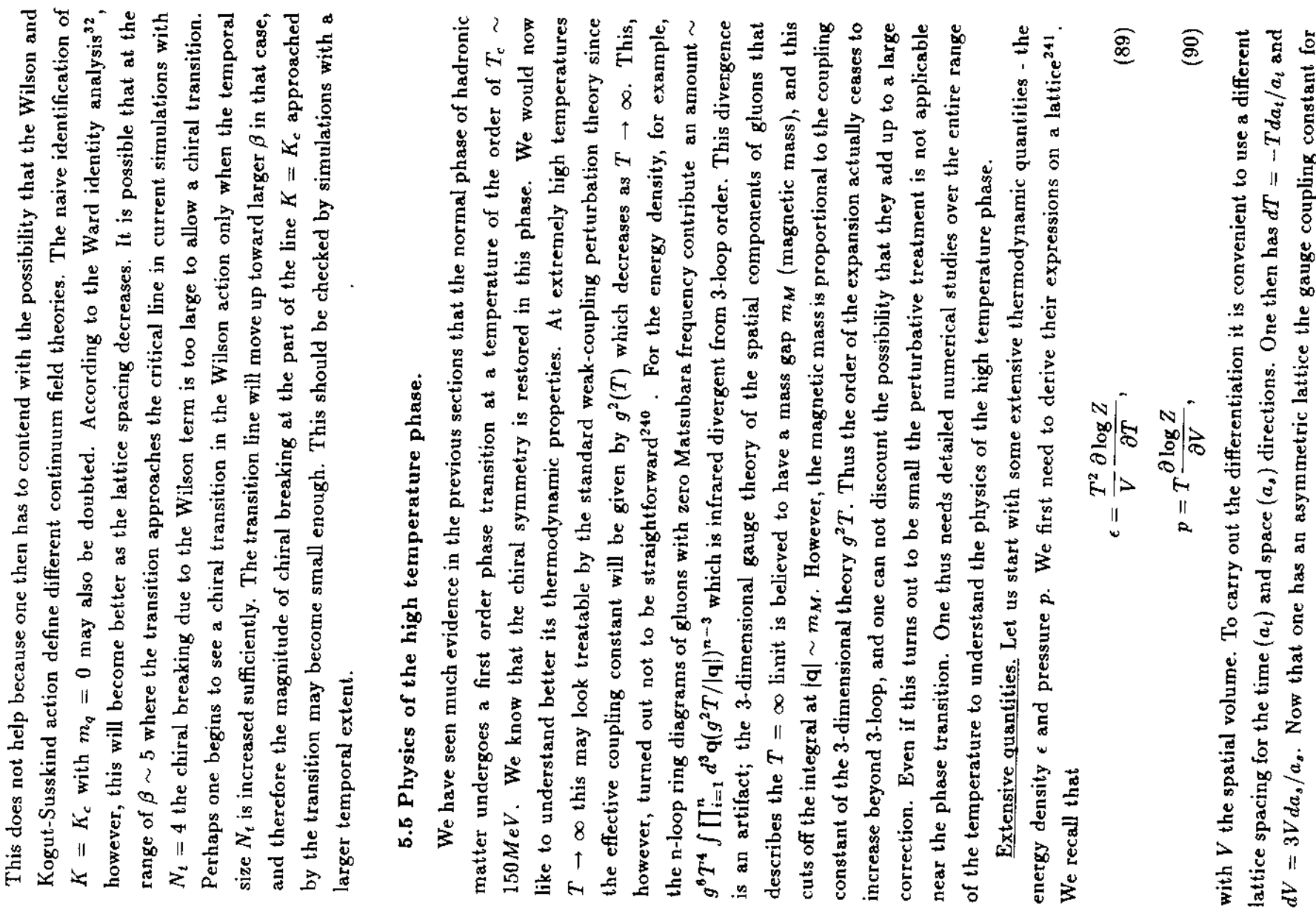

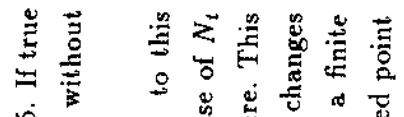

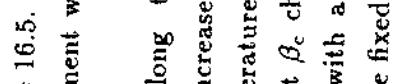

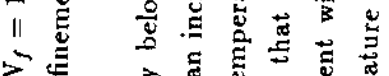

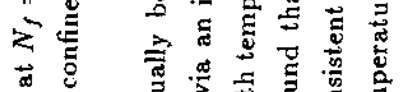

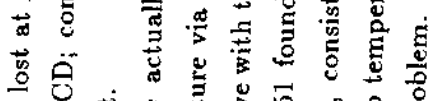

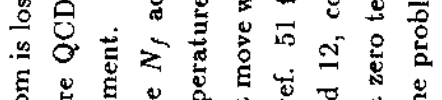

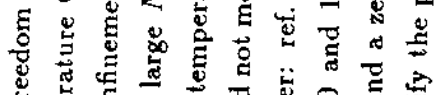

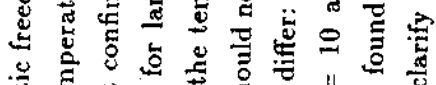

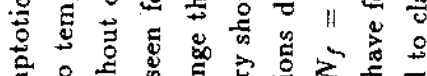

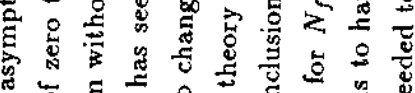

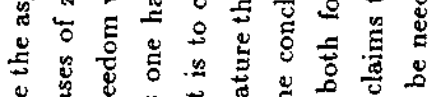

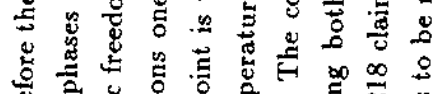

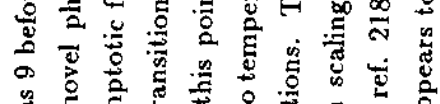

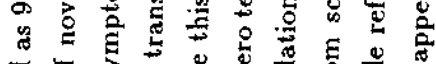

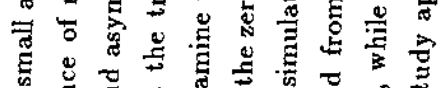
क

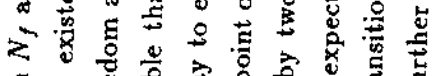

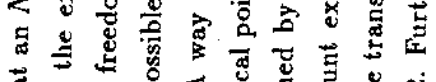
बิ

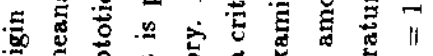

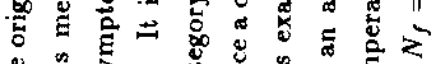

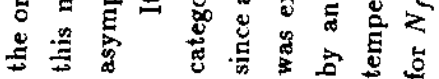

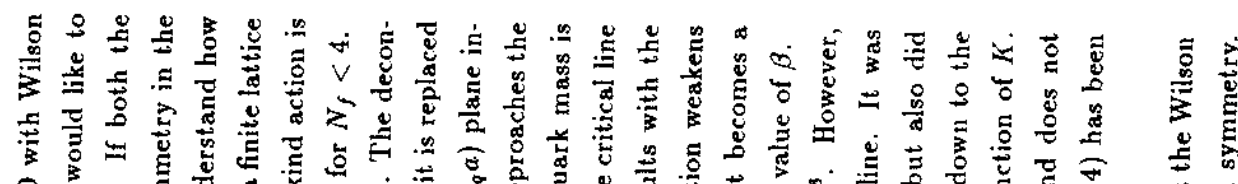

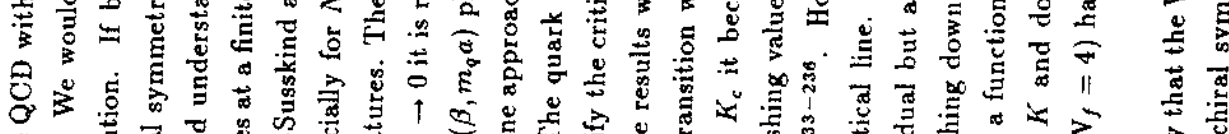

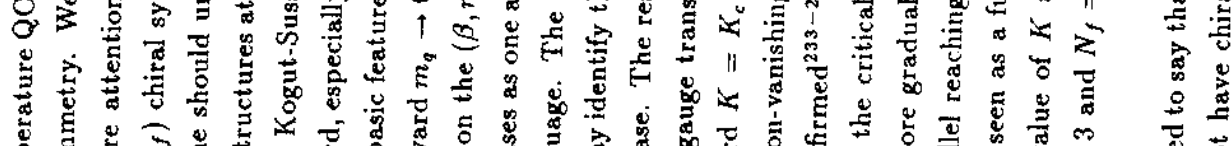

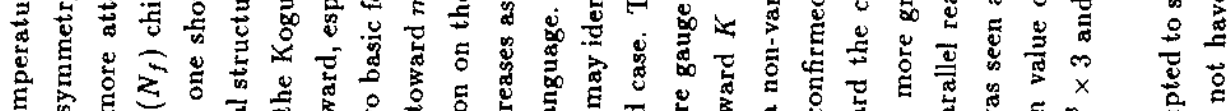

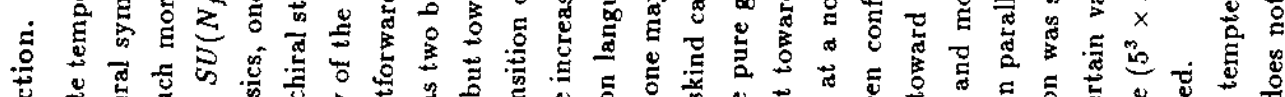

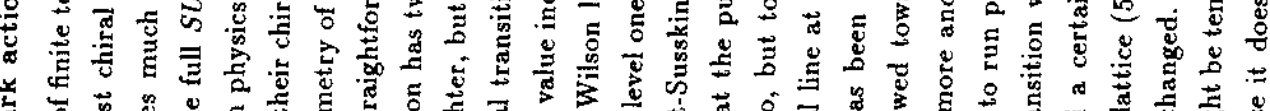

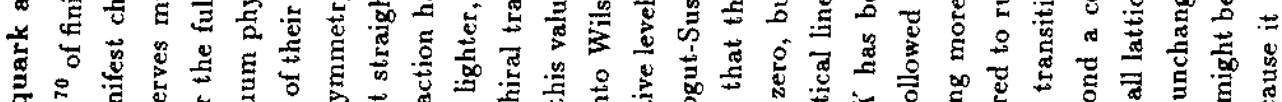

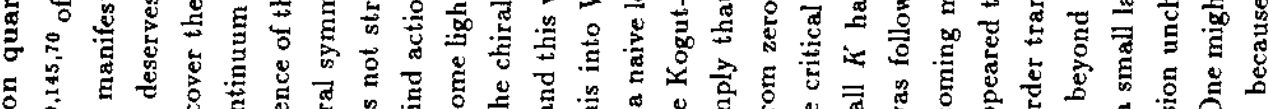

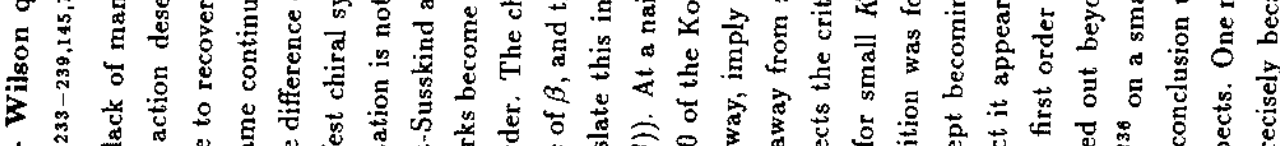

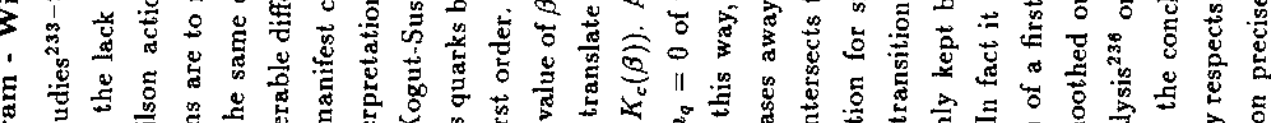

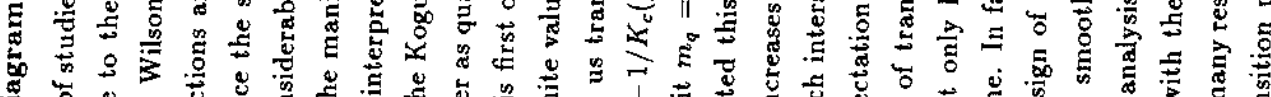

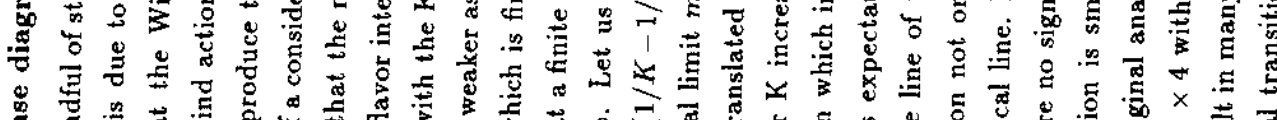

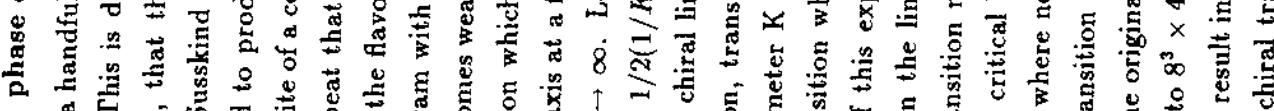
Oी o

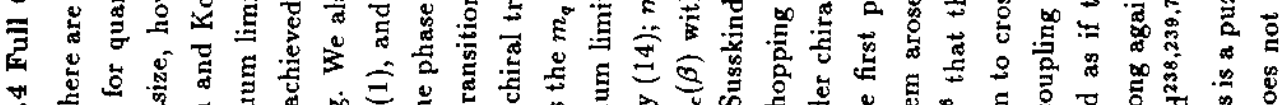

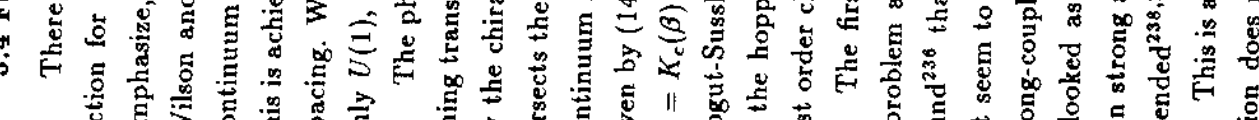

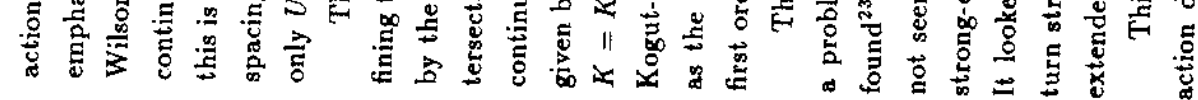




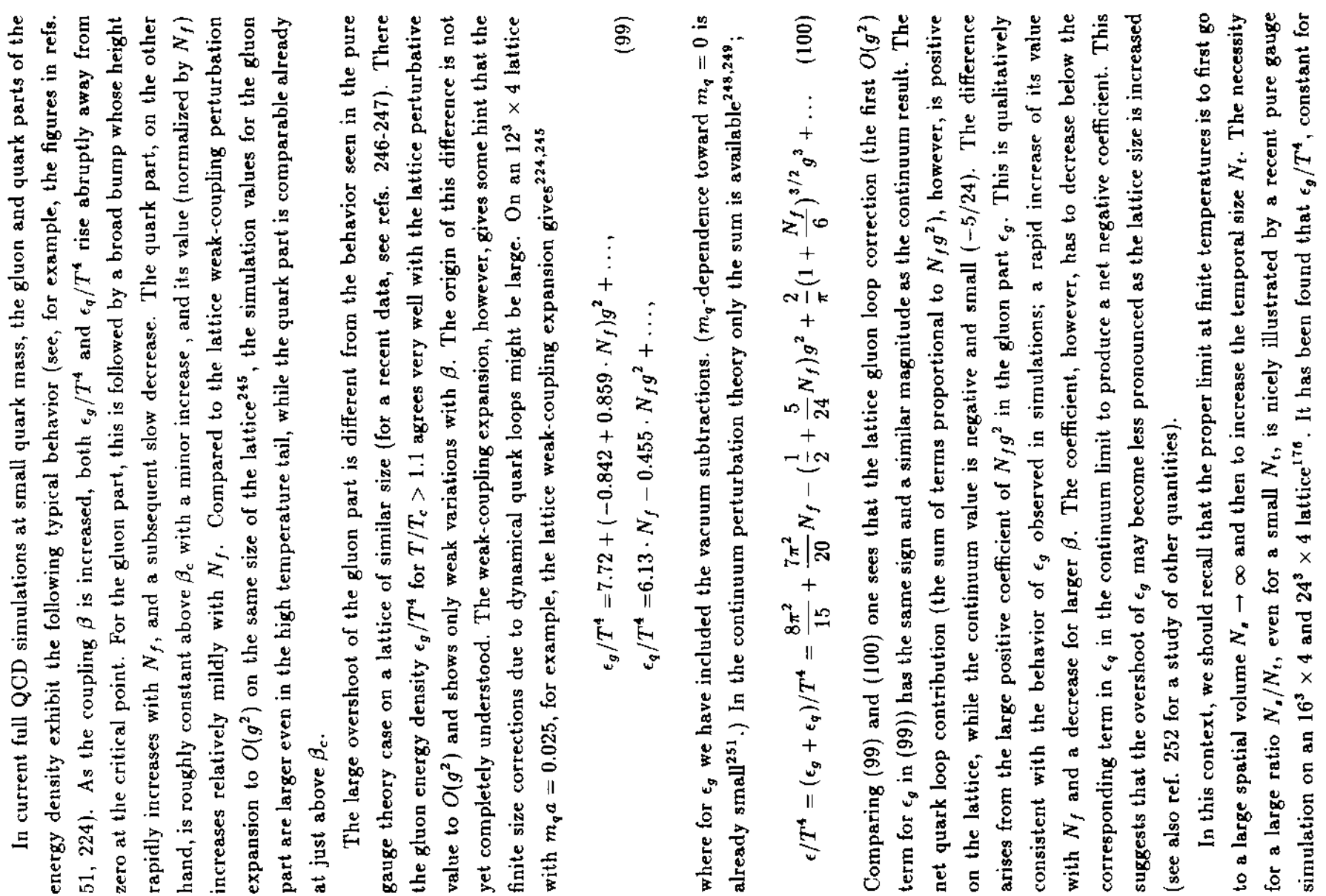

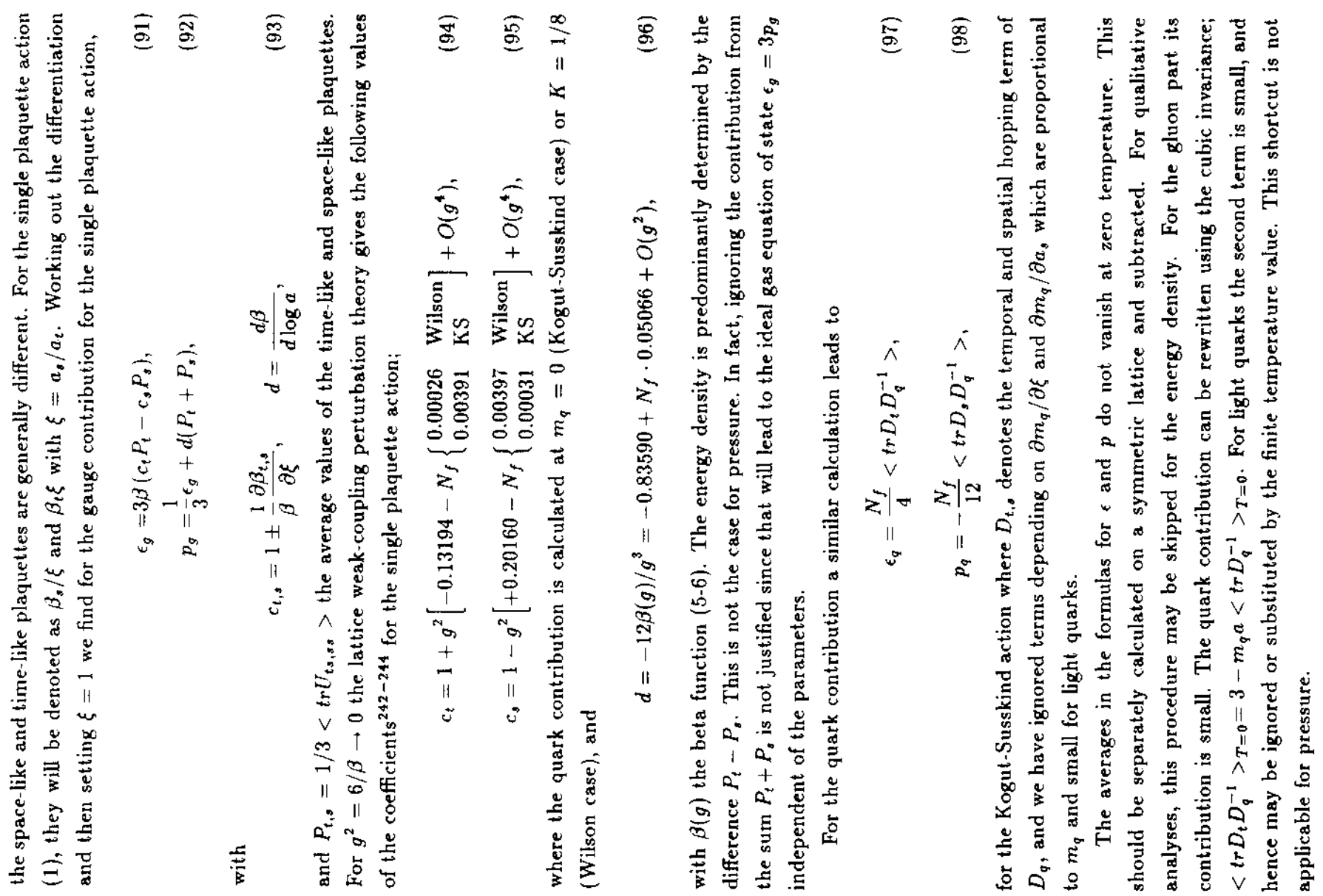




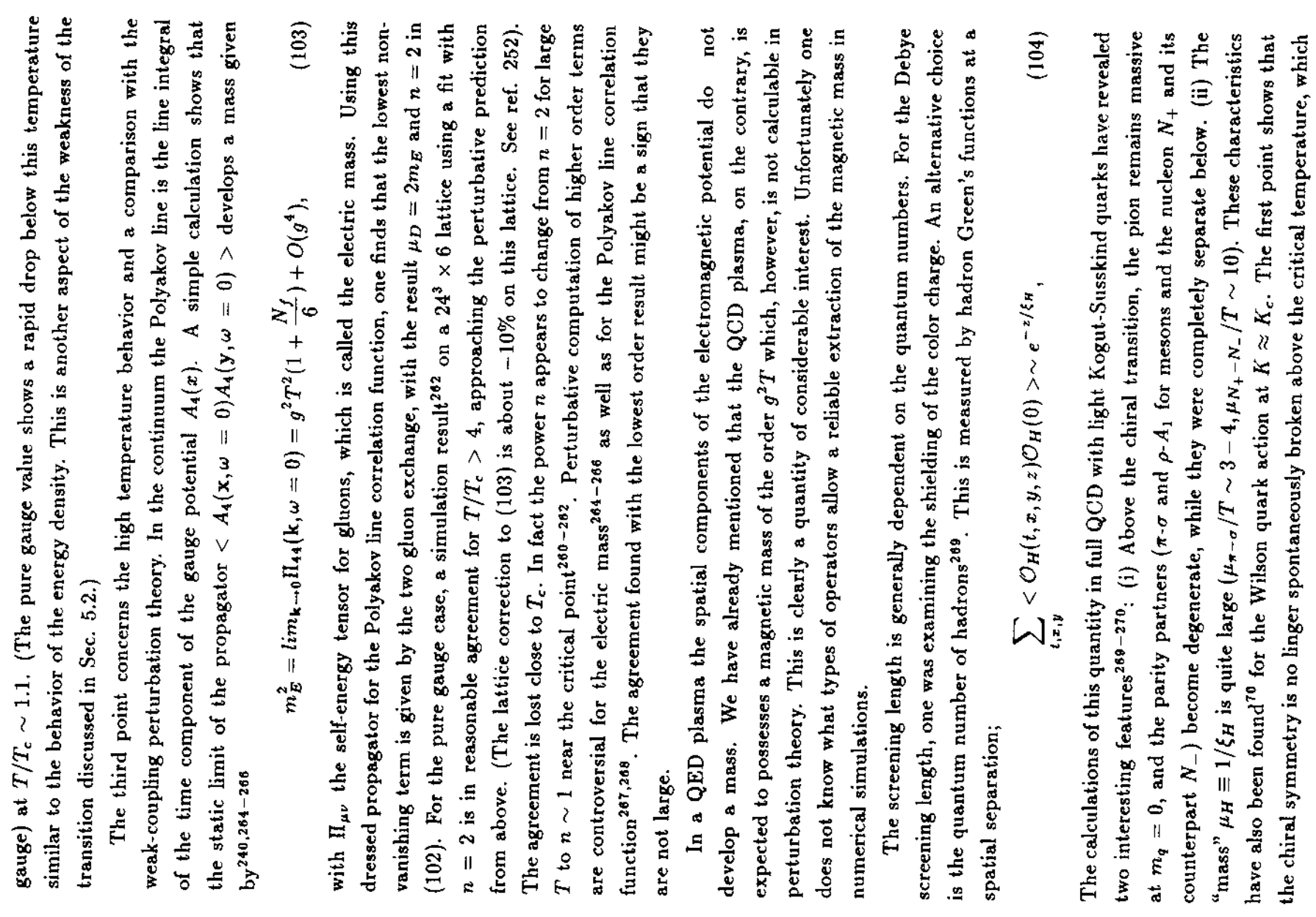

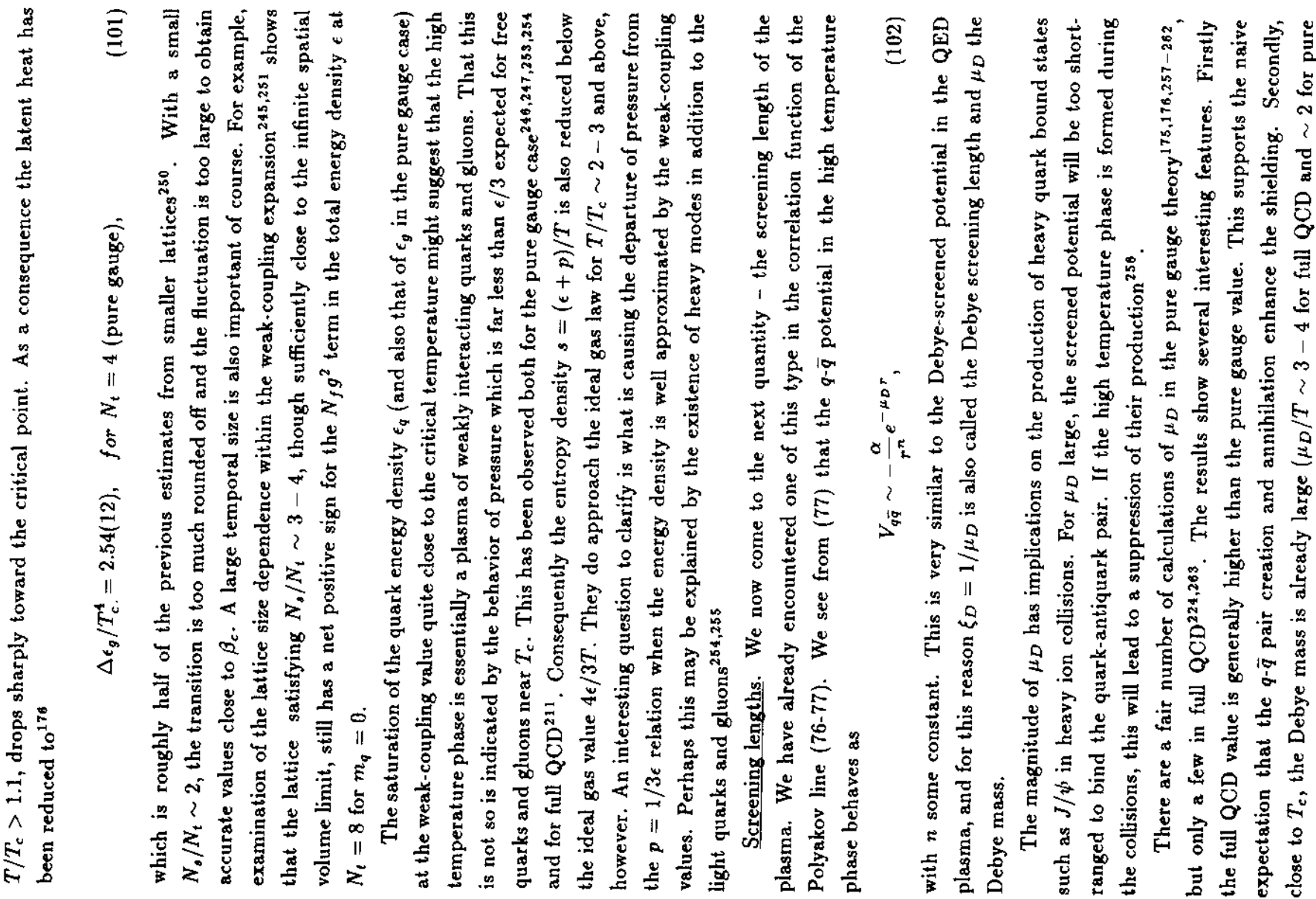




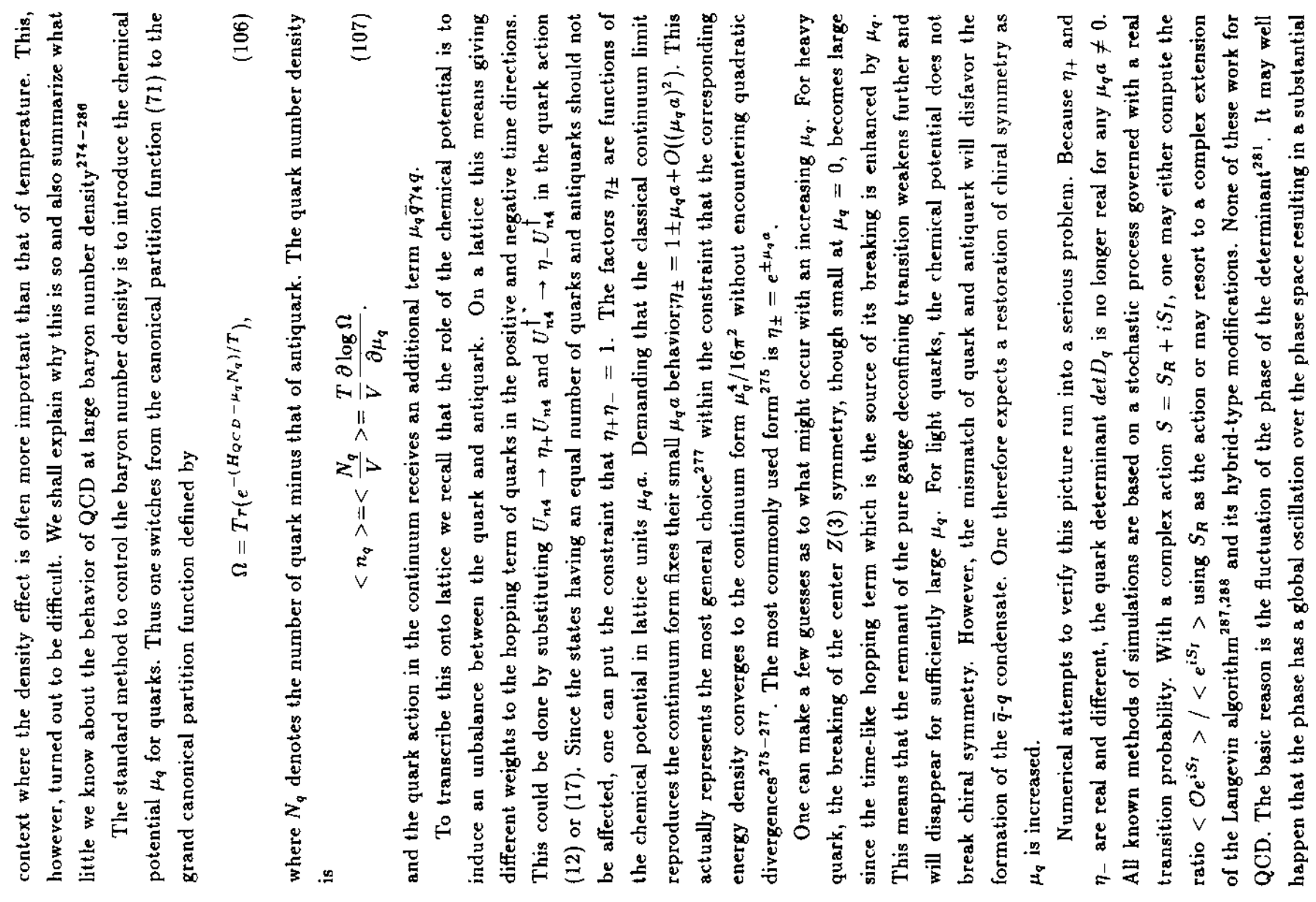

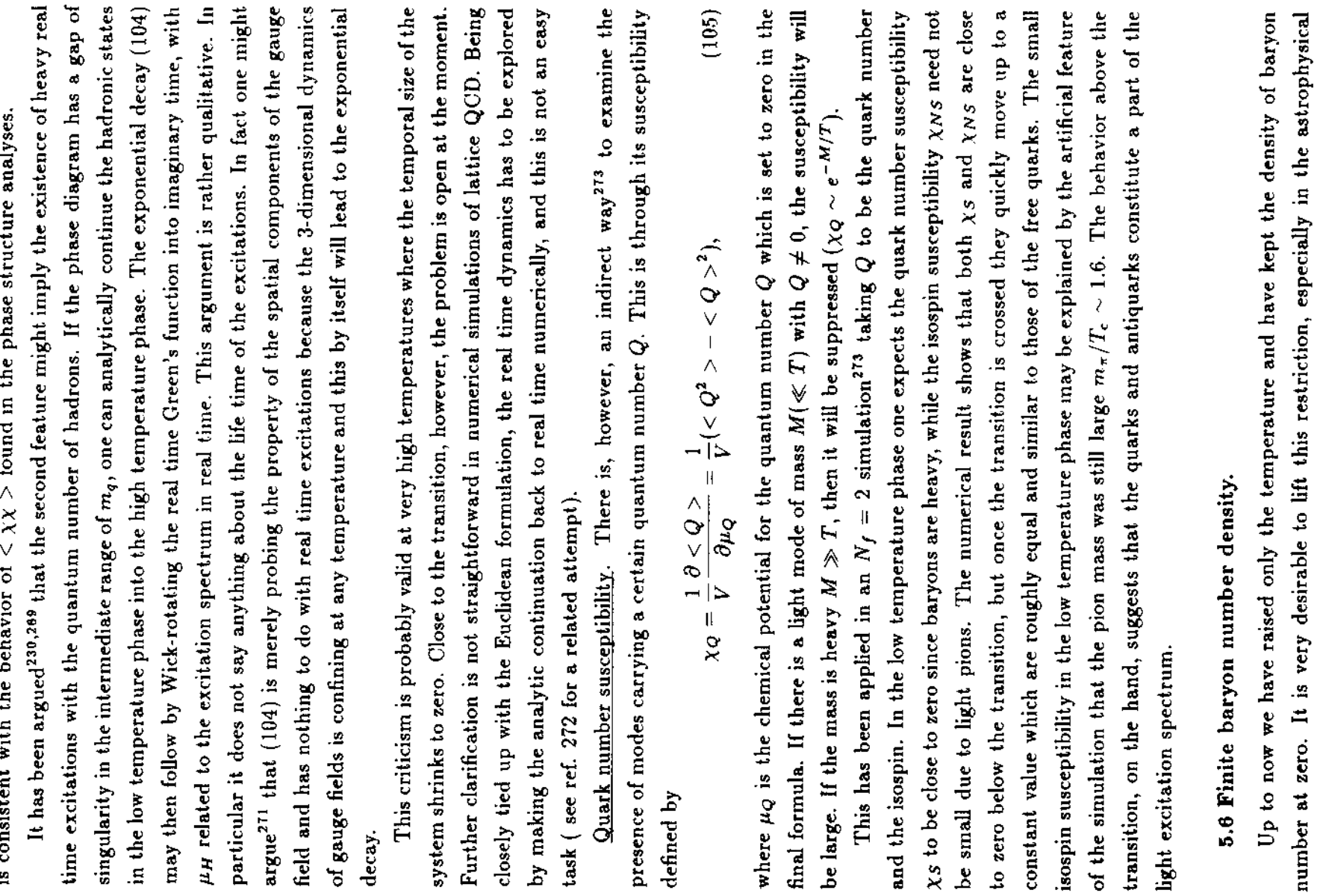




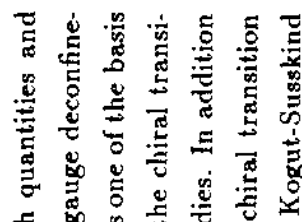

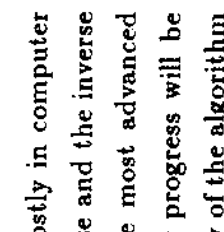

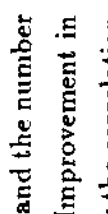

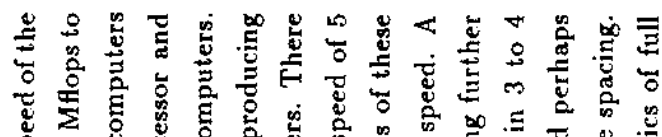

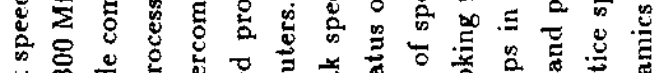

言诸

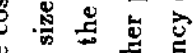

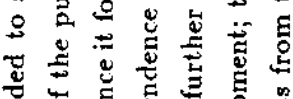

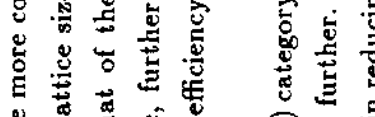

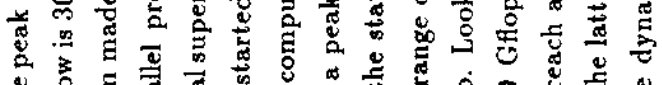

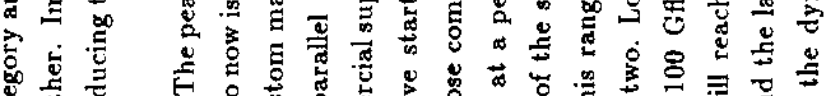

焉至

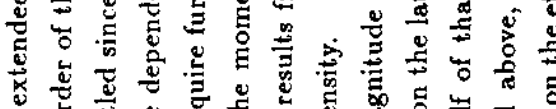

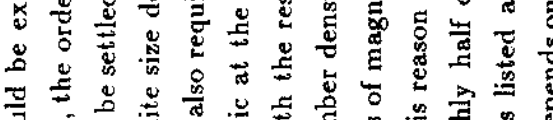

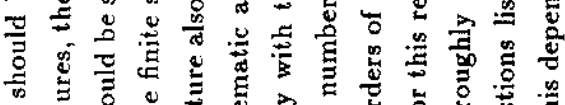

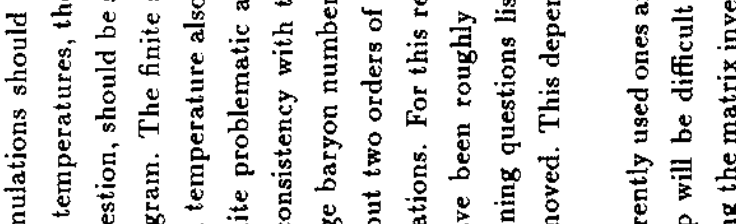

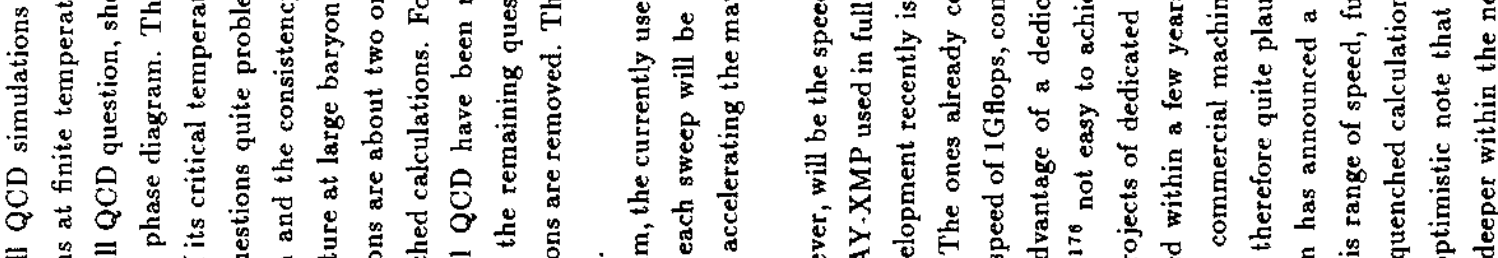

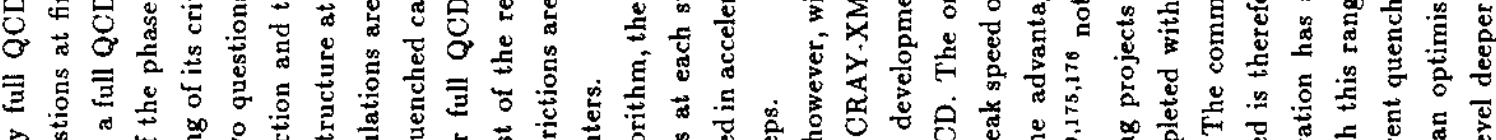

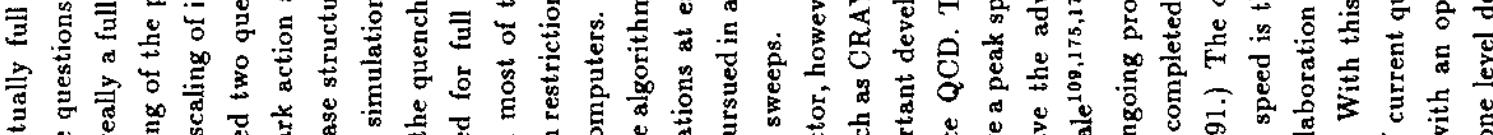

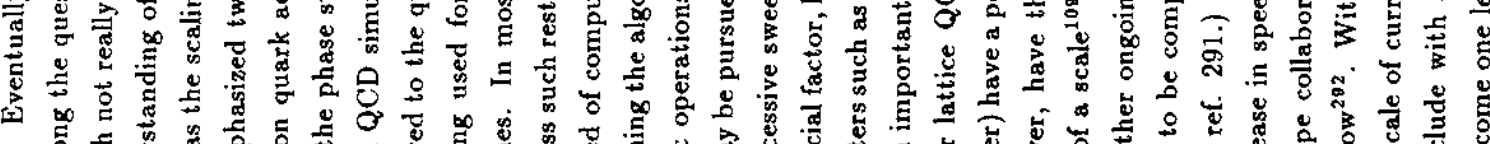

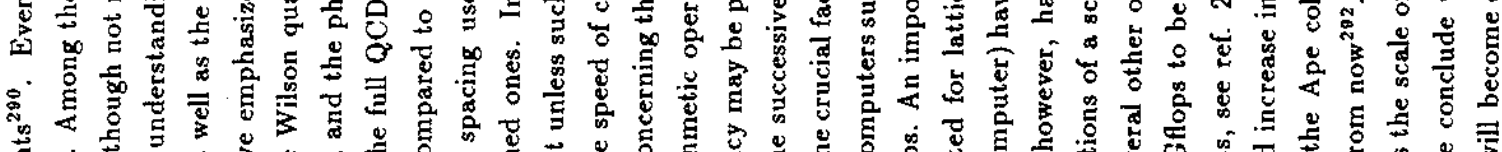

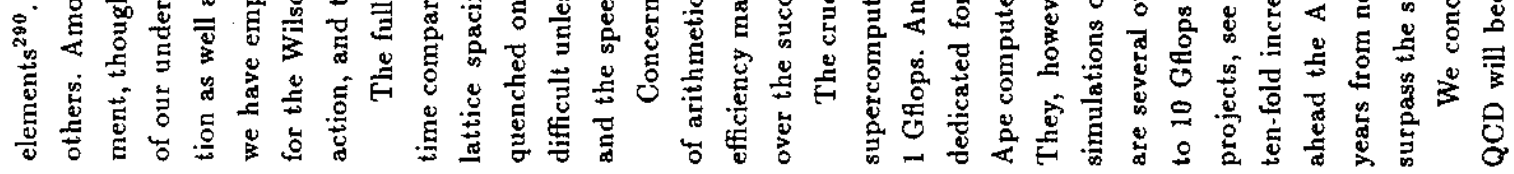

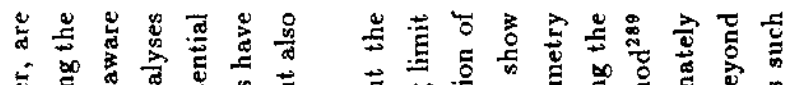

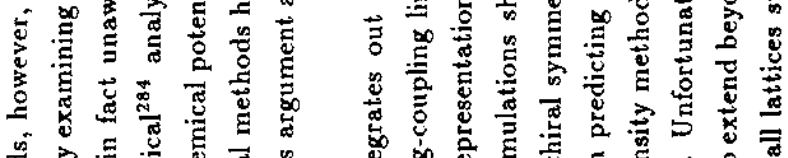

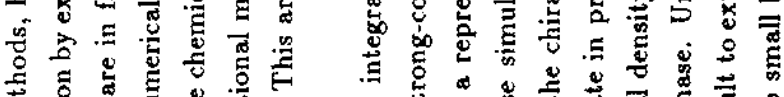

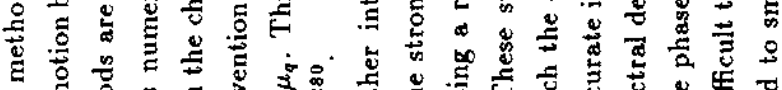

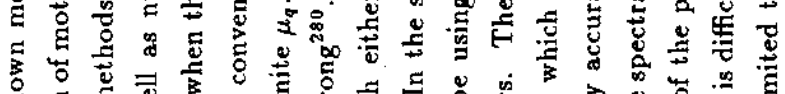

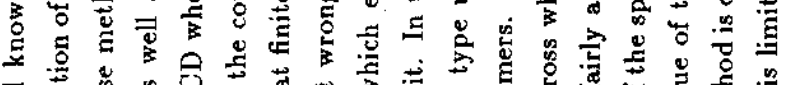

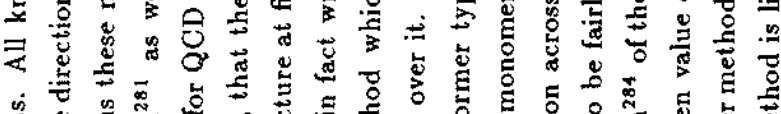

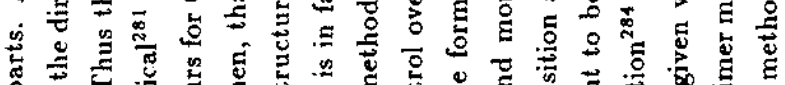

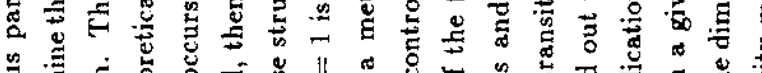

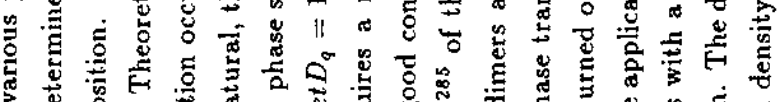

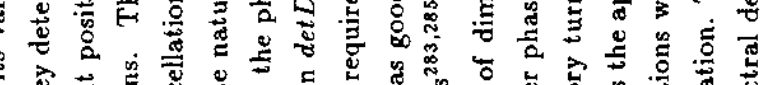

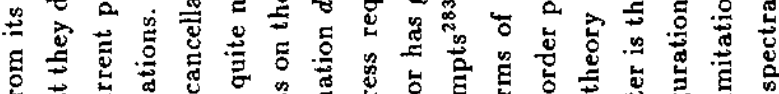

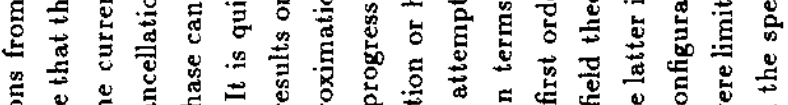

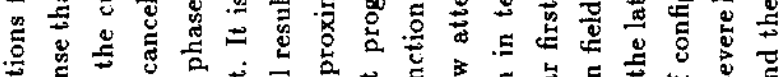

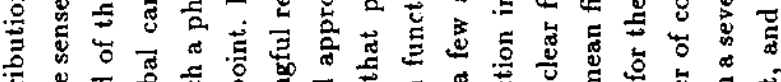

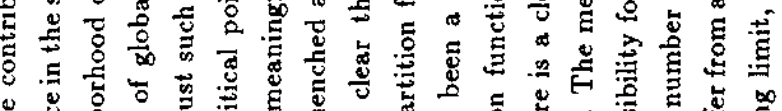

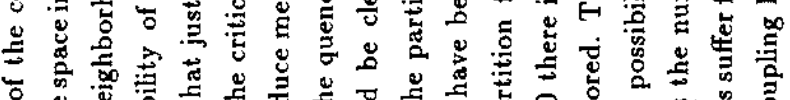

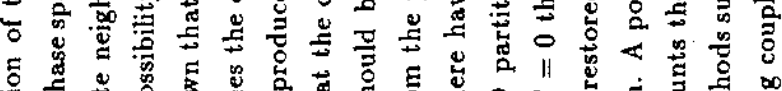

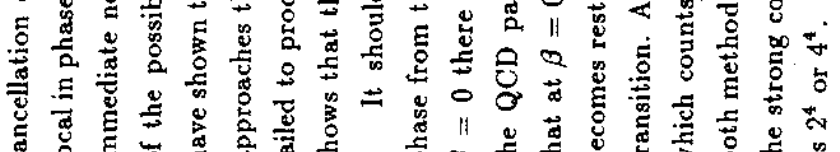

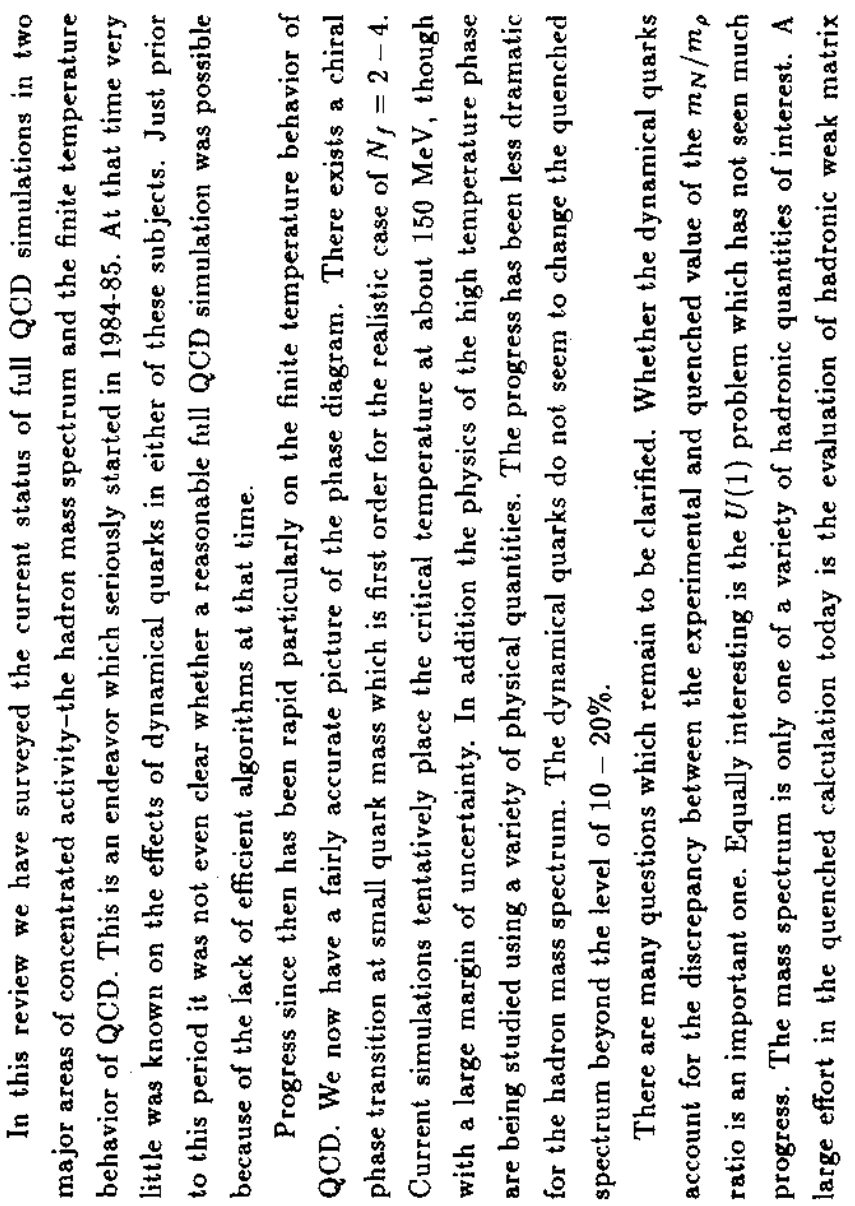



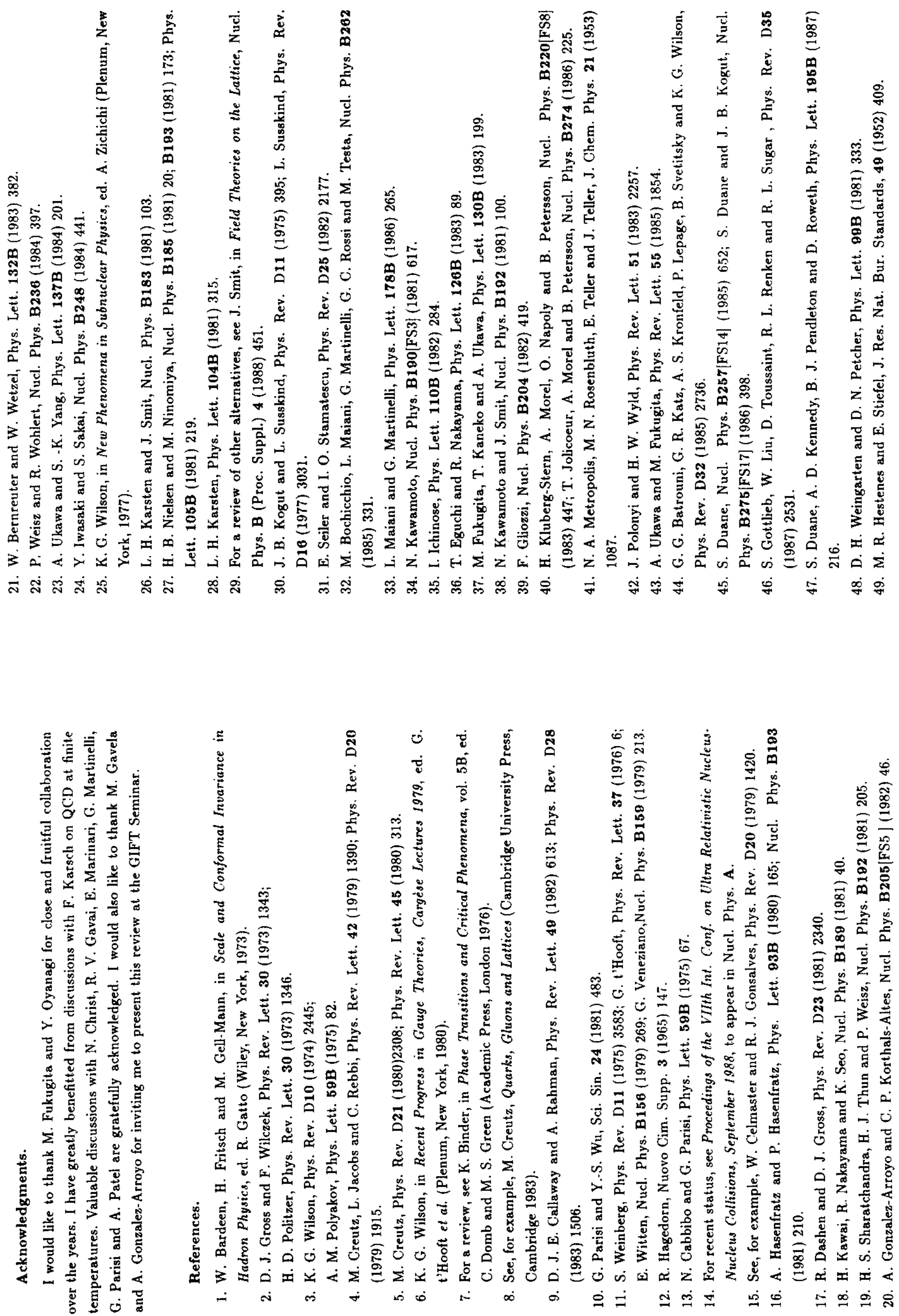

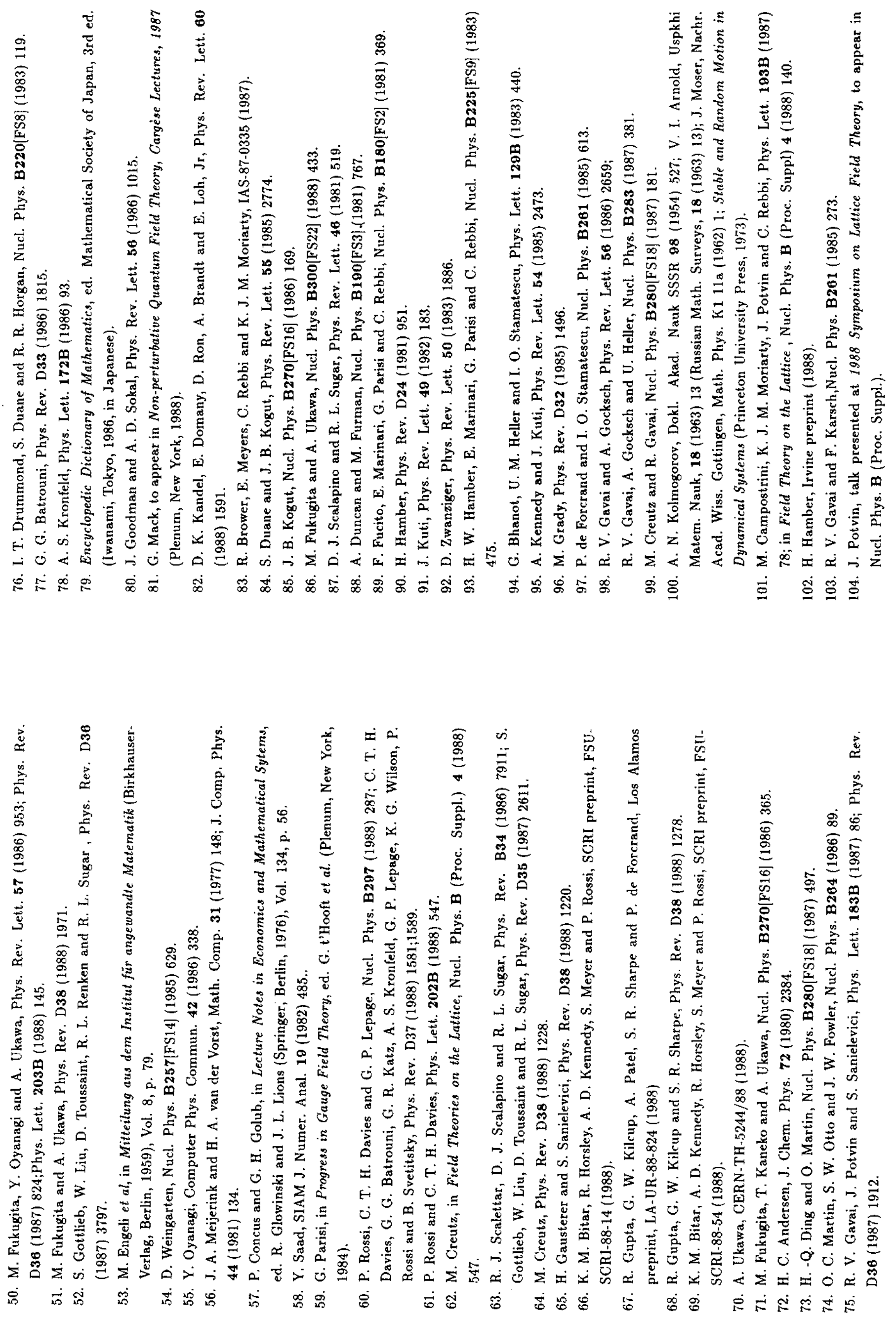

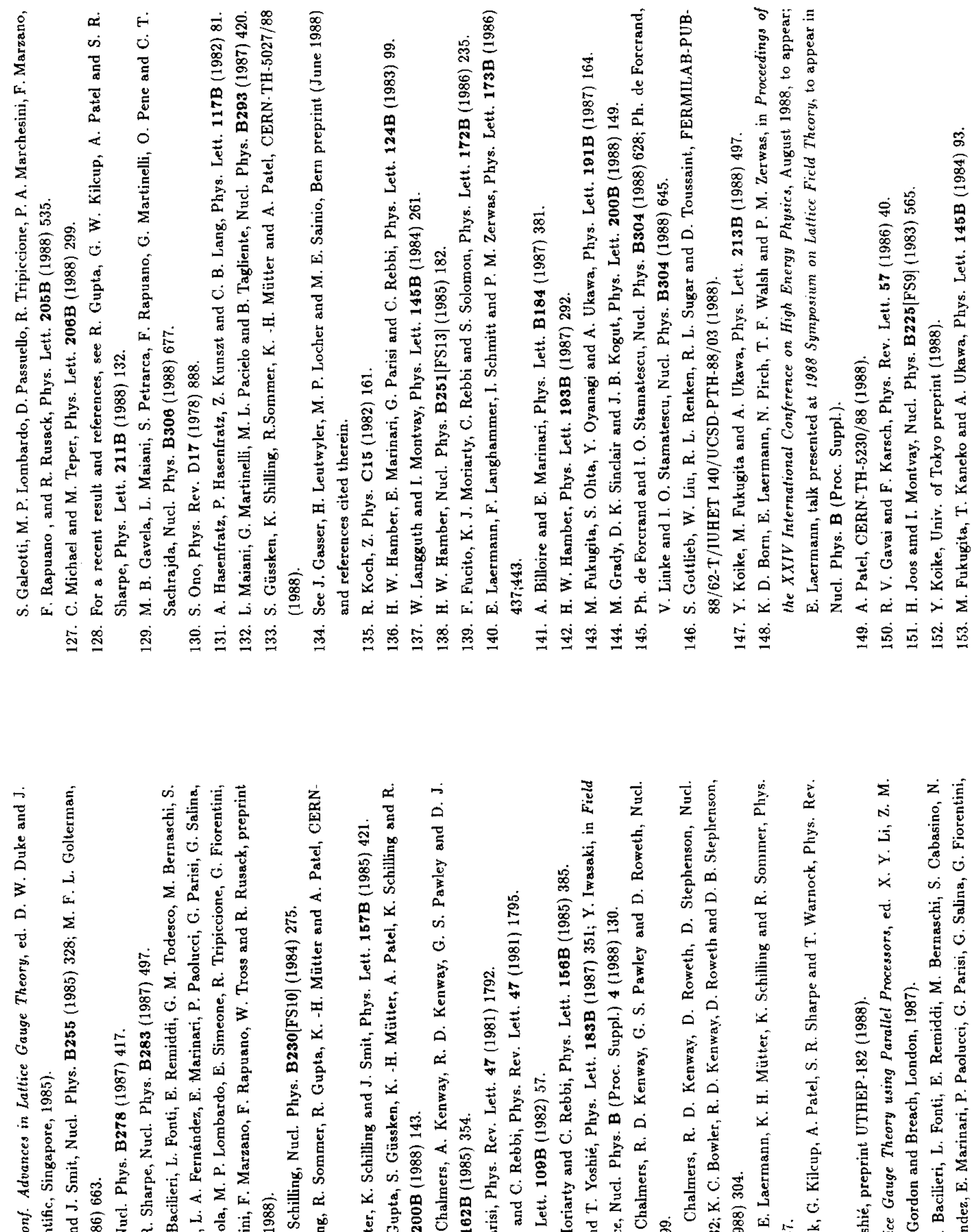

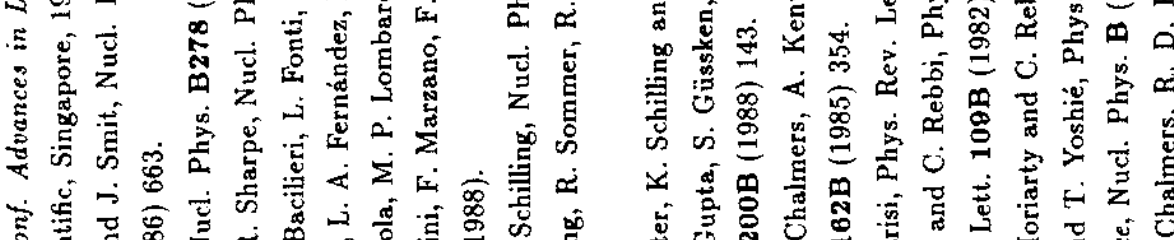
ร) 19

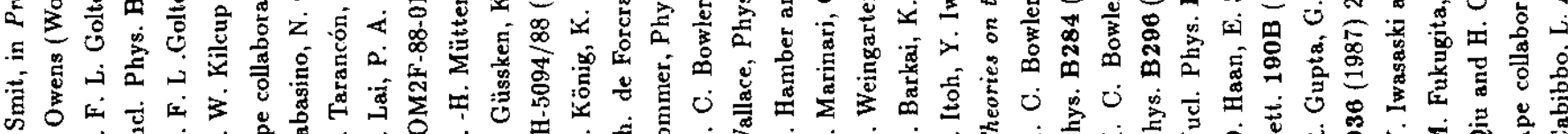

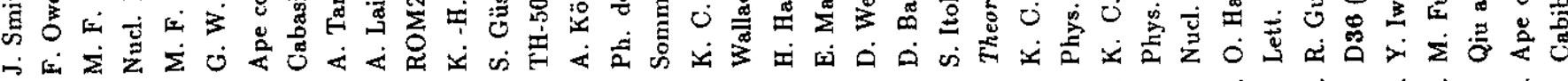

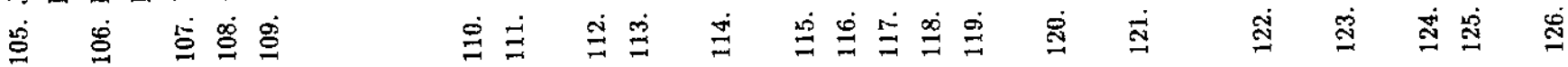




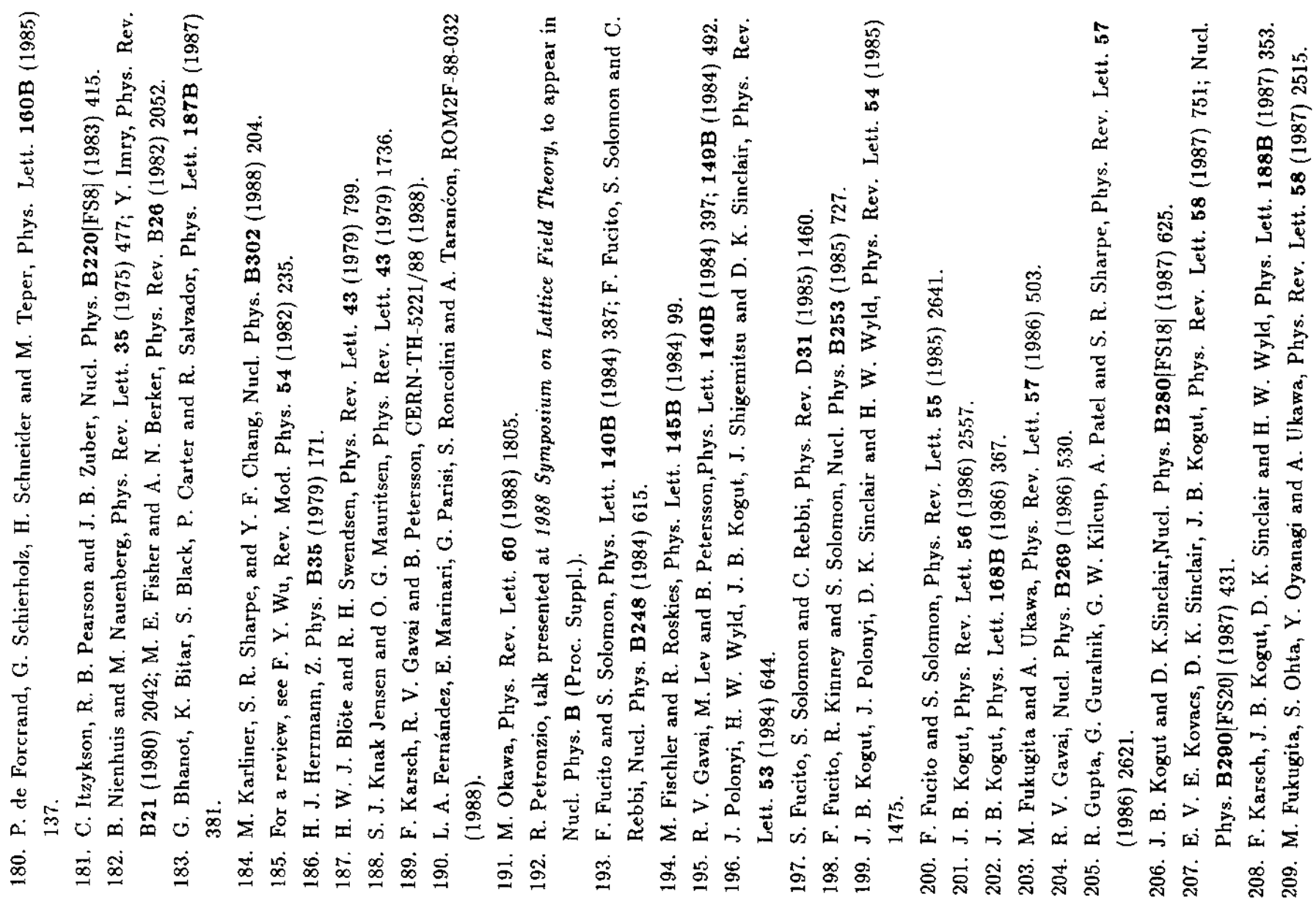

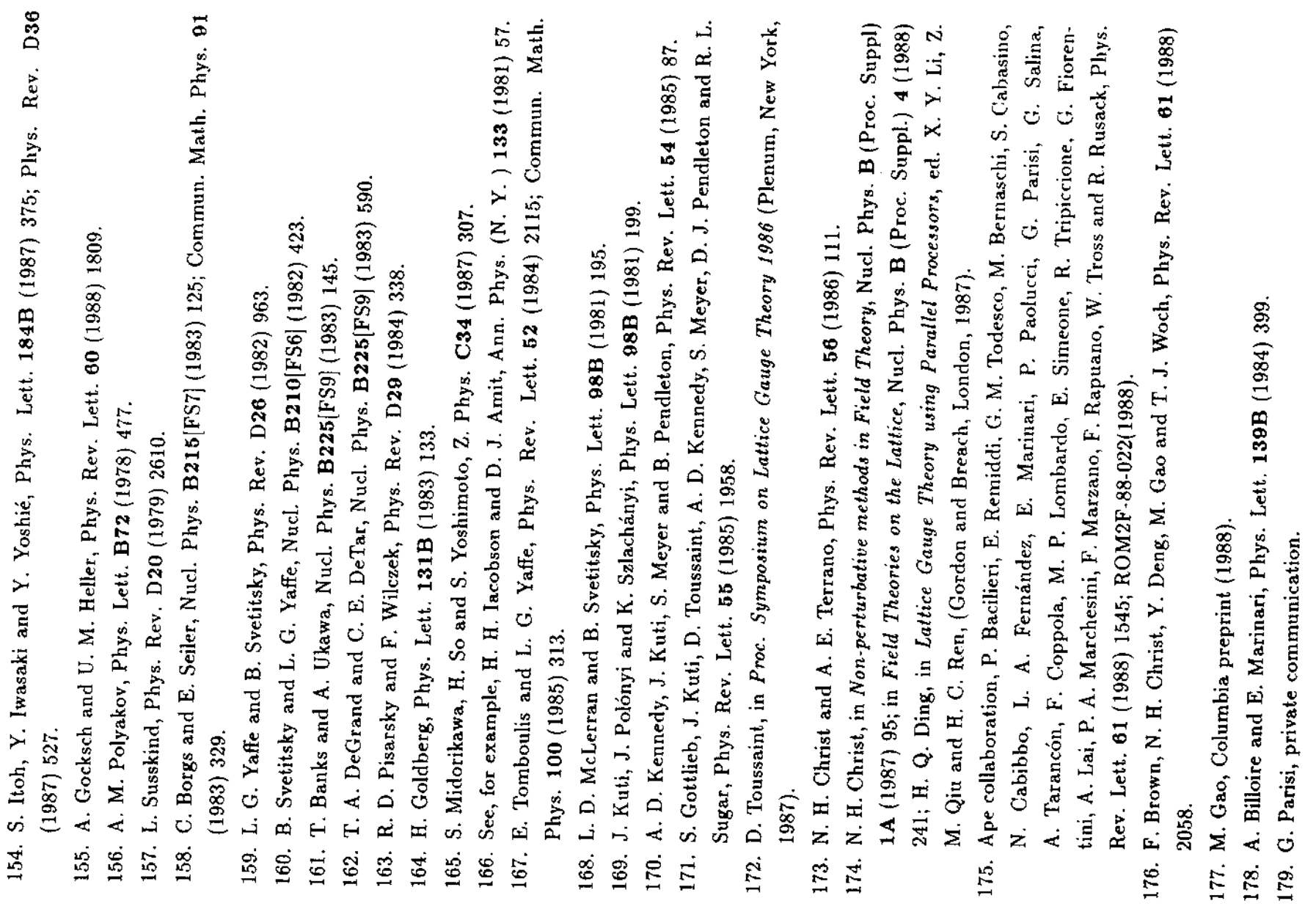




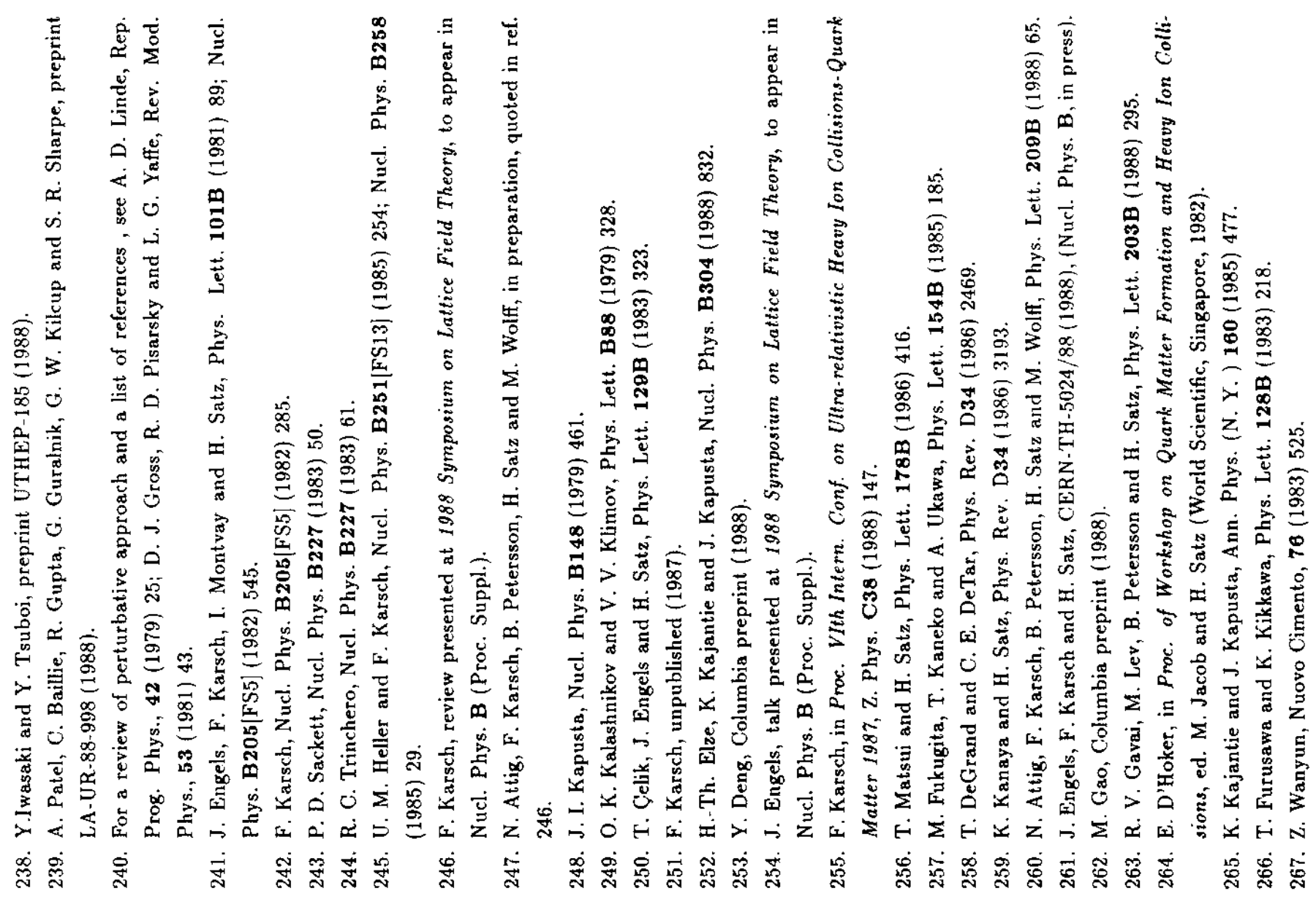

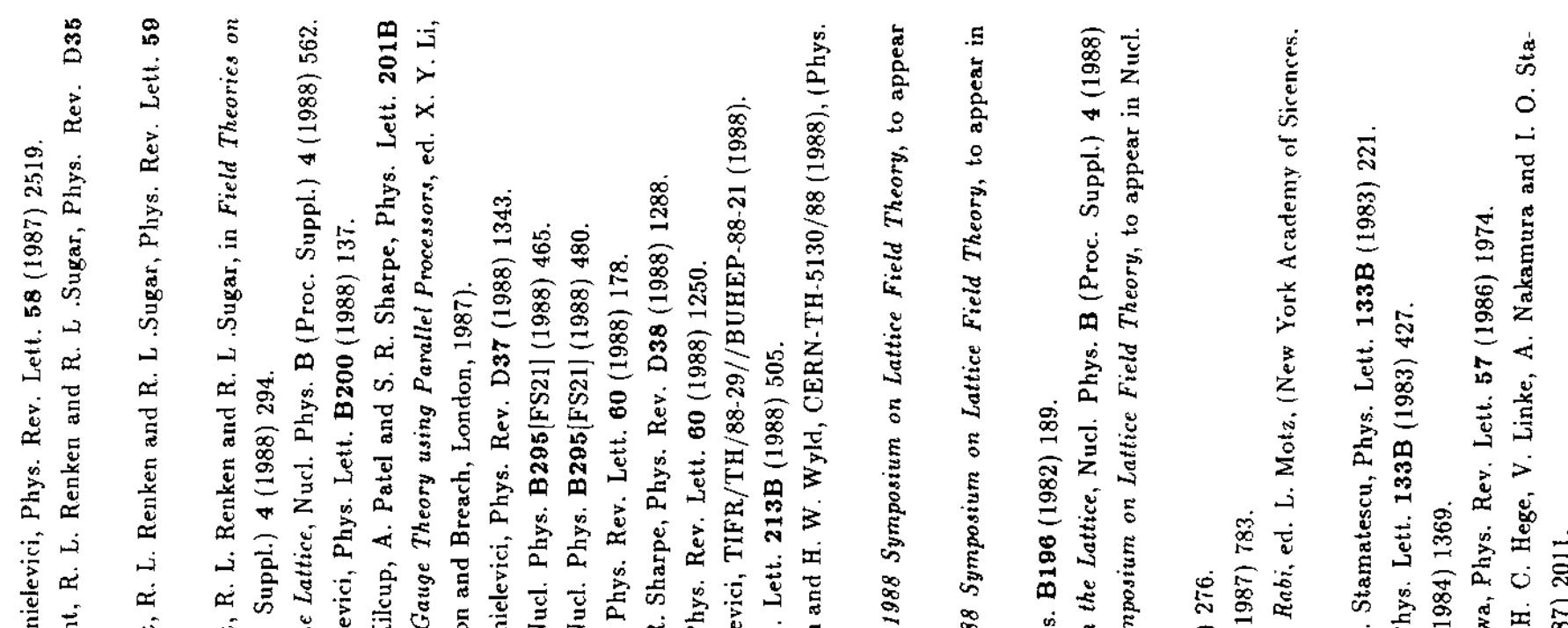

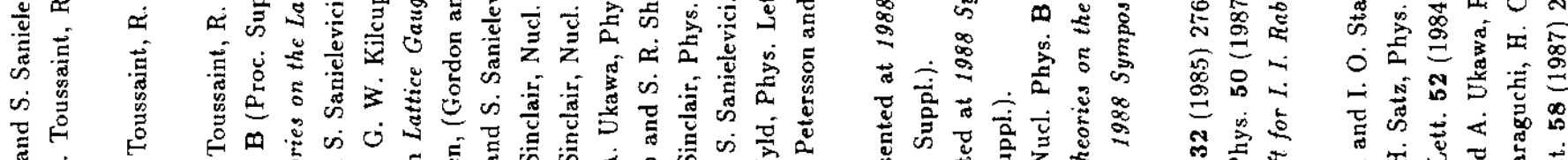

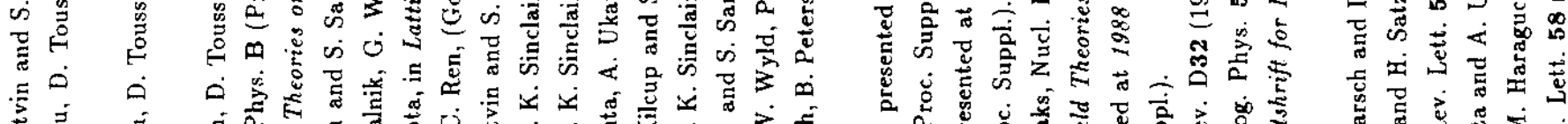

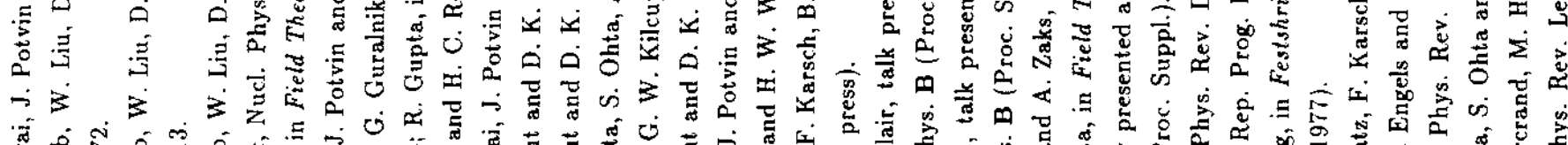

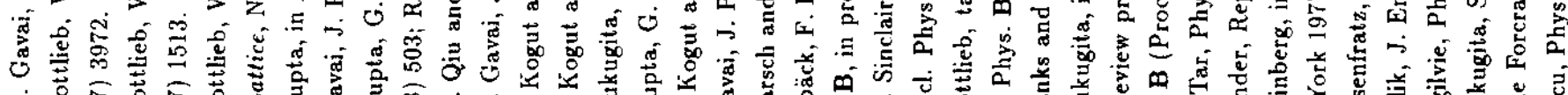

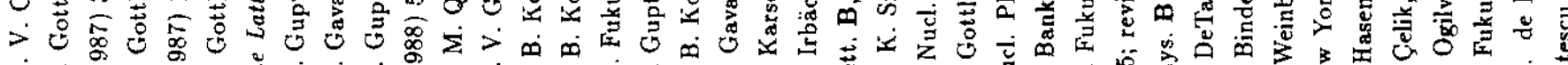

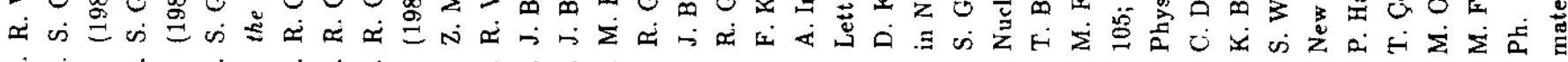

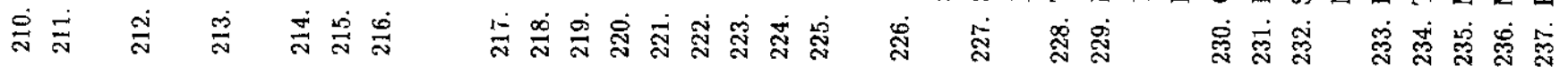




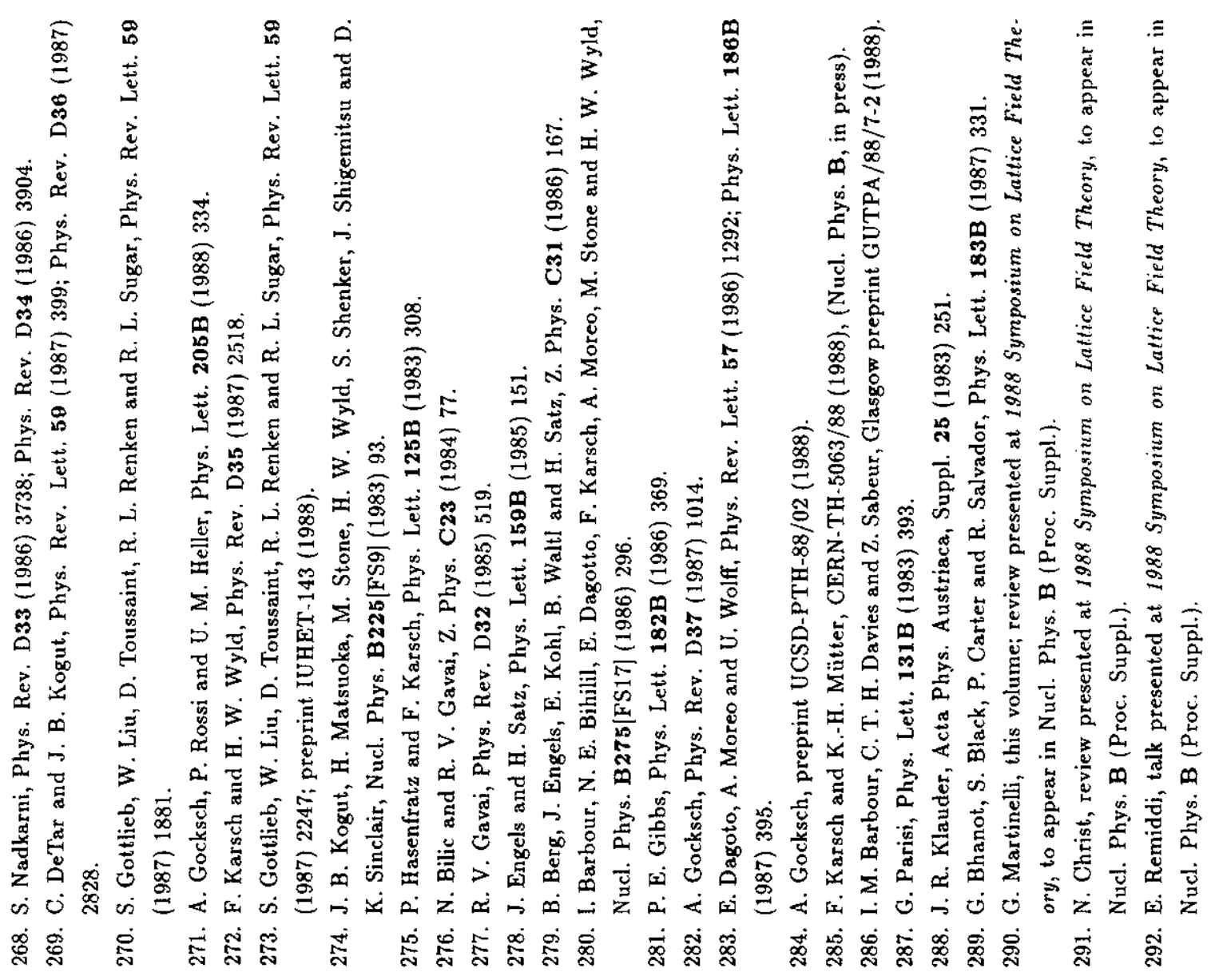

